\title{
Field Evaluation of Hazardous Waste Site Bioassessment Protocols
}
J. M. Thomas
J. F. Cline
J. E. Rogers
C. E. Cushing
L. E. Rogers
M. C. McShane
J. C. Simpson
J. R. Skalski

\section{April 1983}

Prepared for

The U.S. Environmental Protection Agency under a Related Services Agreement with the U.S. Department of Energy

Contract DE-AC06-76RLO 1830

Pacific Northwest Laboratory Operated for the U.S. Department of Energy by Battelle Memorial Institute 


\title{
DISCLAIMER
}

This report was prepared as an account of work spon:ored by an agency of the United States Government. Neither the United Stajes Government nor any agency thereof, nor any of their employees, makes any warranty, express or implied. or assumes any legal liability or responsibility for the accuracy, completeness, or usefulness of any information, apparatus, product, or process disclosed, or represents that its use would not infringe privately owned rights. Reference herein to any specific commercial product, process, or service by trade name, trademark, manufacturer, or otherwise, does not necessarily constitute or imply its endorsement, recomme idation, or favoring by the United States Government or any agency thereof. The views and opinions of authors expressed herein do not necessarily state or r reflect those of the United States Government or any agency thereof.

\author{
PACIFIC NORTHWEST I.ABORATORY \\ operated by \\ BATTELLE \\ for the \\ UNITED STATES DEPARTMENT OI ENERGY \\ under Contract DE-AC06-76RLP 1830
}

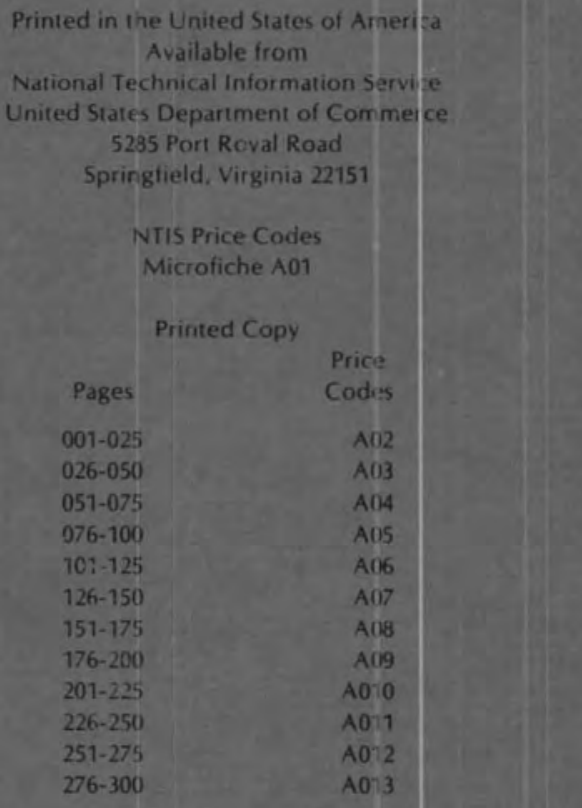



J. M. Thomas
J. F. Cline
C. E. Cushing
M. C. McShane
J. E. Rogers
L. E. Rogers
J. C. Simpson
J. R. Skalski

Apri 1983

Prepared for the U.S. Environmental Protection Agency under a Related Services Agreement with the U.S. Department of Energy Contract DE-AC06-76RLO 1830

EPA Project Manager William E. Miller

Pacific Northwest Laboratory Richland, Washington 99352 


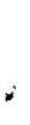




\section{EXECUTIVE SUMMARY}

A workshop entitled "Field Validation of Hazardous Waste Bioassays" held in Denver, Colorado, March 30-31, 1982 proposed and evaluated aquatic, terrestrial, and microbiological field studies which might be used to validate laboratory bioassays. In addition, the participants indicated that certain field bioassessment protocols should be developed as site assessment tools. Scientists at the Pacific Northwest Laboratory (PNL) selected a subset of the proposed studies for both laboratory and field experiments. Field studies were conducted, through a cooperative arrangement, at the U. S. army arsenal in Commerce City, Colorado (RMA). Principal findings were:

- The coefficients of variation for the Selenastmu, lettuce and clover bioassays were on the order of 20,6 , and 14 , respectively, using a slightly contaminated waste trench soil sample.

- No statistically significant differences were noted in bioassay results that could be attributed either to where soil samples were collected in a waste trench, or how the soil samples were subsequently processed.

- Limited data suggest a possible relationship between bioassay results and concentration of chemicals in the soil.

- RMA lake water showed no detectable bioassay depressions and limited physical, chemical, and biological testing indicated that the approach using control lakes recommended by the Denver workshop cannot detect field impacts (at RMA lakes, if they exist).

- Honeybees were found to have a high probability for detecting meaningful mortality effects due to toxic substances. Grasshoppers and microarthropods were both rejected as possible biomonitors.

- Gross changes in field vegetation along suspected chemical gradients can be detected by measurements of relative plant cover. However, analyses of species composition and vegetative structure were required to determine specific areas of potential contamination among plots along three separate transects. 
- A $25 \%$ difference in total small mammal abundance can be detected using an experimental design which incorporates six control and treatment pairs when capture probabilities are about 0.6 .

- A preliminary appraisal of effects on small mammals (except under unusual circumstances, i.e. rodenticide) can se projected from percent cover of forbs, sand dropseed and cheatgrass.

- Using Basin-F water, the dehydrogenase bioassay was found to be more time efficient and cost effective compared to EPA's $\mathrm{CO}_{2}$ bioassay.

- A sclerotial bioassay showed good sensitivity toward Basin-F water and some initial promise as a mutagenic assay.

- Modifications of the Neubauer plant bioassay resulted in a technique whereby soil, rather than eluates, could be used in concert with the current EPA standard bioassay for seed germination. The new technique is inexpensive, reproducible and all material is disposable.

- In four plant bioassays, $1 \%$ Basin-F water caused reduced germination and leaf growth for wheat and completely inhibitec lettuce germination.

- In the agronometric field study recommended by the Denver workshop were to be conducted, about $1 \%$ Basin-F water should be used as one of the treatments. 


\section{ACKNOWLEDGEMENTS}

Many people who don't appear on the title page contributed to this research and the production of the document. At the Rocky Mountain Arsenal, Dr. Bill McNeil and Dr. Michael Witt helped arrange for field work on the site. Dr. Dave Thorn, Dr. Bill Trautman and Dr. Brian Anderson provided valuable assistance in the field. At the Pacific Northwest Laboratory, Steve Edland, Les Eberhardt, Peter Beedlow, Marji Cochran, Ken Gano, and Shu Mei Li assisted in the field and in the laboratory. Dan McKenzie, Ray Wildung, Bill Rickard and Gene Schreckhise provided technical guidance. Rene Hinds edited the report and Gail Poole and Karen Tallent typed the manuscript. 


\section{CONTENTS}

EXECUT IVE SUMMARY ACKNOWLEDGEMENTS

1.0 INTRODUCTION

2.0 SITE SELECTION AND SOIL SAMPLING • • • • • • • • • • • • • • • 3

2.1 SOILS FOR SEED GERMINATION AND SOIL MICROORGANISM BIOASSAYS $\quad 3$

2.1 .1 Introduction . . . . . . . . . . . . . . . 3

2.1 .2 Methods . . . . . . . . . . . . . . . . 4

2.1 .3 Results • • • . • . • . • • • • • . • . 7

2.2 STATISTICAL ESTIMATION OF VARIANCES $\quad . \quad \cdot \quad \cdot \quad \cdot \quad \cdot \quad \cdot \quad \cdot \quad \cdot \quad 7$

2.2.1 Introduction • • • • • • • • • • • • • • • 7

2.2 .2 Methods . . . . . . . . . . . . . . . . 7

2.2 .3 Results . . . . . . . . . . . • . . . . . 14

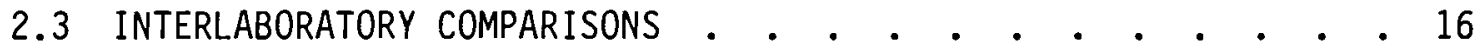

2.3.1 Introduction . • • • • • • . • • • • • • . 16

2.3 .2 Methods . . . . . . . . . . . . . . . 16

2.3 .3 Results • • • • . • • • • • • • • • • . 16

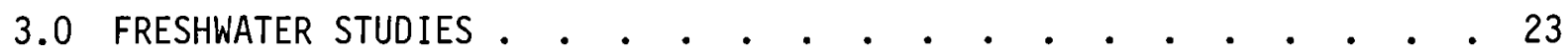

3.1 INTRODUCTION • • • • • • • • • • • • • • • • • • • 23

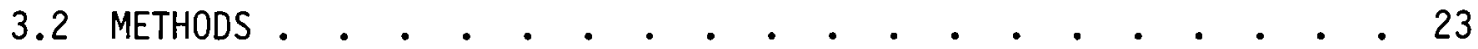

3.3 RESULTS • • • • • • • • • • • • • • • • • •

3.4 CONCLUSIONS • • • • • • • • • • • • • • • . . 29

3.5 REFERENCES . • • • • • • • • • • • • • • • • • • 30

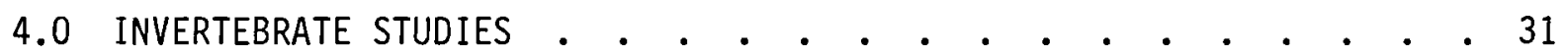

4.1 INTRODUCTION

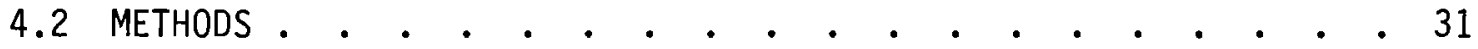

4.3 RESULTS • • • • • • • • • • • • • • • • • • • 32

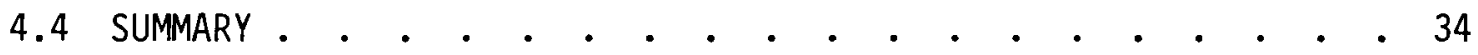

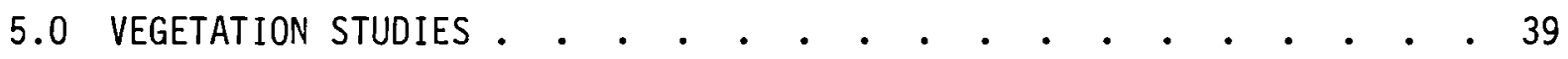

5.1 INTRODUCTION

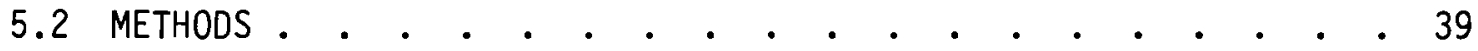

5.3 RESULTS • • • • • • • • • • • • • • • • • •

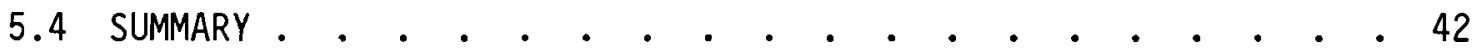


5.5 REFERENCES . • . . . • . . . . . . . . . . . . 42

6.0 SMALL MAMMAL STUDIES . . . . . . . . . . . . . . . . 47

6.1 INTRODUCTION . . . . . . . . . . . . . . . . . . 47

6.2 METHODS . . . . . . . . . . . . . . . . . . . 448

6.2.1 Small Mammal Studies . . . . . . . . . . . 48

6.2.2 Concurrent Vegetation Studies . . . . . . . . . 49

6.3 RESULTS . . . . . . . . . . . . . . . . . . . . . 49

6.3.1 Smal1 Mammal Abundance Estimates and Associated
Variance Components . . . . . . . . . . . . . 49

6.3.2 Replicate Sma11 Mammal Plots Needed to Detect Impacts . 56

6.3.3 Floral Densities and Sampling Variances . . . . . . 56

6.3.4 Evaluation of Pairing Success of Small Mammal Communities Using Clustering Algorithms . . . . . 59

6.3.5 Evaluating Pairing Success of Plant Communities Using Clustering Algorithms . . . . . . . . . 60

6.3.6 Multivariate Regression of Small Mammal Communities on Plant Community Data . . . . . . . . . 61

6.4 SUMMARY . . . . . . . . . . . . . . . . . . . 63

6.5 REFERENCES . . . . . . . . . . . . . . . . . 64

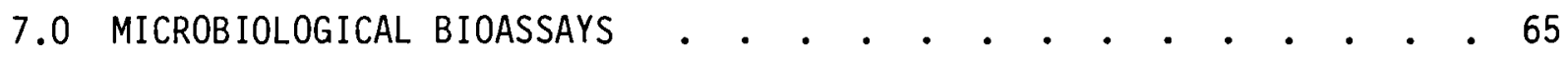

\begin{tabular}{l}
7.1 LABORATORY STUDY OF CO PRODUCTION AND COMPARISON WITH \\
DEHYDROGENASE BIOASSAY.. \\
\hline
\end{tabular}

7.1 .1 Introduction . . . . . . . . . . . . . . . 65

7.1 .2 Methods . . . . . . . . . . . . . . . 65

7.1 .3 Results . . . . . . . . . . . . . . . 65

7.1 .4 Summary . . . . . . . . . . . . . . . 69

7.2 DEVELOPMENT OF SCLEROTIAL BIOASSAY . . . . . . . . . 70

7.2.1 Introduction . . . . . . . . . . . . . . 70

7.2 .2 Results . . . . . . . . . . . . . . 70

7.2 .3 Summary . . . . . . . . . . . . . . . . 71

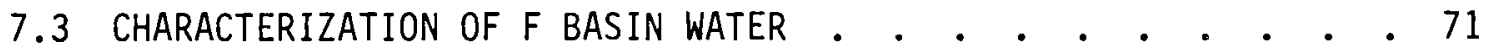

8.0 LABORATORY PLANT BIOASSAYS . . . . . . . . . . . . . . 73

8.1 INTRODUCTION . . . . . . . . . . . . . . . . 73

8.2 METHODS . . . . . . . . . . . . . . . . . . . 73

8.3 RESULTS . . . . . . . . . . . . . . . . . . . 74

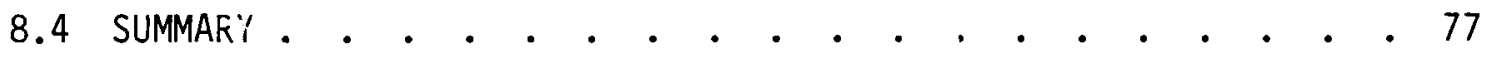




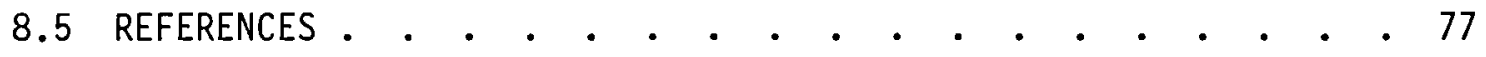

APPENDIX A - DENVER WORKSHOP PROGRAM . . . . . . . . . . . . A.1

APPENDIX B - STATEMENT OF WORK . . . . . . . . . . . . . . . B.1

APPENDIX C - FY82 PROJECT PLAN . . . . . . . . . . . . . . . C.1

APPENDIX D - LOCATION OF 1982 FIELD SAMPLING SITES AT ROCKY MOUNTAIN

ARSENAL . . . . . . . . . . . . . . . . . . . D.1 


\section{FIGURES}

2.1 Control Field Plot and Location of Random Soil Samples at RMA . . 6

2.2 Preliminary Map of Vegetation on the Control Soil Plot (Section 24; June 23, 1982) . . . . . . . • . . . . . • . . . . 8

2.3 Field Site and Sample Locations for Contaminated Soil in Section 1.10

2.4 Vegetation at the Ditch Soil Sampling Site Seztion 1, June 23, 1982 . . . . . . . . . . . . . . . . . . 13

2.5 Approximate Location of Soil Samples Taken in Basin A . . . . . 17

2.6 Location of Vertical Soil Samples Taken Near the Mouth of Ditch and Upper Derby Lake . . . . . . . . . . . . . . . . . 18

2.7 Location of Vertical Soil Sample Taken in Basin C . . . . . . 19

2.8 Control Field Plot Located in Section 24 and location of Additional Samples (October 22, 1982) . . . . . . . . . . 20

3.1 Study Lakes in the Denver Area: (1) Berkeley: (2) Rocky Mountain, (3) Crown Hill, (4) Mary, (5) Ladora . . . . . . . . . 25

5.1 Hypothetical Plant Transect Showing Field Sampling Design for Vegetation and Soil (See also Figure 2.7) . . . . . . . 40

5.2 Detailed Results of a "TWINSPAN" Analysis of Flant Species Composition for Three Plant Transects at Rocky Mountain Arsenal . 43

5.3 Summarized Results of "TWINSPAN" Analyses of Plant Species Composition for Three Transects . . . . . . . . . . . . 45

6.1 Comparison of Power Curves for Detecting an Impact on Small Mammal Communities at Rocky Mountain Arsenal . . . . . . . . . 57 


\section{TABLES}

2.1 Chemical Content of Soil in Section 23 . . . . . . . . . . 5

2.2 Preliminary Soil Chemistry for Upper Derby Waste Trench . . . . 9

2.3 Sample Identification and Allocation to Obtain Variance Component Estimates of Bioassays, Soil and Laboratories . . . . 12

2.4 Results of Battel le Columbus Laboratories' Chemical Analyses for Pesticides and Selected Bioassays of Upper Derby Trench Soil . . . 15

2.5 Identification of Soil Samples Collected 10/21/82 at RMA . . . . 21

3.1 Chemical, Physical, and Biological Data Collection and Analysis Methods Used for Denver Area and RMA Lakes . . . . . . . . . 26

3.2 Physical-Chemical Data, (Mean of Three Samples) Obtained at Denver Area and RMA Lakes. . . . . . . . . . . . . . . . 27

3.3 Results of Plankton Sampling at Denver Area and RMA Lakes . . . . 28

3.4 Calculated Condition ( $K$ ) Factors for Denver Area and RMA Lakes . . 30

4.1 Mortality of Honeybee Brood and Amount of Pollen Collected at Rocky Mounta in Arsenal . . . . . . . . . . . . . 33

4.2 Summary of Grasshopper Abundance Estimates at Rocky Mountain Arsenal $\left(\bar{x}=100\right.$; plots $\left.=1 \mathrm{~m}^{2}\right) .$. . . . . . . . . . . . . 34

4.3 Estimates of Microarthropod Numbers of Rocky Mountain Arsenal . . 35

4.4 Summary of Microarthropod Abundance Collected at Rocky Mountain Arsenal . . . . . . . . . . . . . . . 36

4.5 Comparison of Honeybees, Grasshoppers and Microarthropods as Useful Fuels Biomonitors $(+=$ Useful Characteristics) . . . . . . . 37

5.1 Results of Cover Analys is for Three Plant Transects at Rocky Mounta in Arsenal . . . . . . . . . . . . . . . . . 42

5.2 Species List for Gradient Analys is Vegetation Sampling at Rocky Mountain Arsenal . . . . . . . . . . . . . . 44

6.1 Number and Percent of Small Mammals Captured Over Five Days by Species and by Plot at Rocky Mountain Arsenal During June 1982 . . 50

6.2 Chi-Square Values $\left(x_{2}^{2}\right)$ and Associated Significance Levels for Pairwise Tests of Homogeheous Capture Probabilities (Across All Plots) Using Mark-Recapture Data . . . . . . . . . . . 51

6.3 Chi-Square Values $\left(x_{2}^{2}\right)$ and Significance Levels for the Pairwise Tests of Homogeneous Capture Probabilities (Pooled Across A11 Plots) Using Removal Sampling Data . . . . . . . . . . 52

6.4 Results of Statistical Tests of Homogeneity and Goodness-of-Fit of Model Assumptions to Abundance Estimators and Decision on Appropriate Estimation Technique for Small Mammal Species. 
6.5 Estimates of Abundance for Small Mammal Species at Eight Replicate Plots at Rocky Mountain Arsenal . . . . . . . . . . . 54

6.6 Estimates of Mean Abundance $\left(\mu_{N}\right)$, Between Area Variance $\left(\sigma_{A}{ }^{2}\right)$, the Variance Between Plots-Within-Areas $\left(\sigma_{P} A^{2}\right)$ and Average Safipling Error $\left(\sigma_{S E}\right)$ (Estimated from Daily Captlire Probabilities) for Small Mammal Species at RMA . . . . . . . . . . . . . . . 54

6.7 Product Moment Correlation Coefficient for Species Abundance Between Plots-Within-Areas (Estimated with 2 Degrees of Freedom) . • • 55

6.8 Estimates of Plant Cover and Sampling Variances for Predominant Plant Species, Litter, Bare Soil and Total Cover at Eight Plots at RMA (Variance Estimates in Parentheses) and Number of Replicate Daubenmire Plots that Must be Sampled per 1 ha Area to Estimate Mean Density with a Precision of $\pm 5 \%$ of the Mean $95 \%$ of the Time . 58

6.9 Comparison of Small Mammal Abundance Estimates with Values Predicted by the Multivariate Regression Equation (Predictions in Parentheses) . . . . . . . . . . . . . . . . 62

7.1 Elemental Analysis of Ground Alfalfa Used to Amend Soil from Rocky Mountain Arsenal . . . . . . . . . . . . . . 66

7.2 Results of $\mathrm{CO}_{2}$ Bioassay (Heterotrophic Mineralization) after

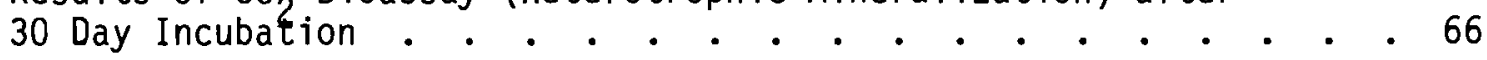

$7.3 \mathrm{NO}_{3}{ }^{-}$and $\mathrm{NH}_{4}{ }^{+}$in Soil ( $\mu \mathrm{g} / \mathrm{g}$ dry weight) After 30 Day Incubation . . 67

7.4 Soil Microbial Biomass (Dehydrogenase) After 30 Day Incubation . . 68

7.5 Effects of Basin $F$ Water and Well Water on Fungal Sclerotial Formation . . . . . . . . . . . . . . . . 69

7.6 Some Properties and a Chemical Analys is (ppm) of Basin F Water and Basin F Well Water. . . . . • . . . . • . . . . . 72

8.1 Effect of Basin $F$ Water on Wheat Seed Germination, and Leaf Length and Water Usage . • . . . • • • • • • • • • • 75

8.2 Wheat and Lettuce Germination When Grown on Soils 76 


\subsection{INTRODUCTION}

Discovery, control and clean up of hazardous environmental spills depends on a complete and accurate knowledge of how hazardous chemicals behave when released to the environment. It is the goal of the Hazardous Materials Assessment Research Program to provide scientific and technical information that will enable clean up of hazardous substances following spills or closures of waste sites. The EPA is mandated these responsibilities by the Comprehensive Environmental Resource Compensation and Liability Act (CERCLA, passed in 1980 and the Resource Compensation and Recovery Act RCRA, passed in 1976).

An initial step in providing the needed information was made with the identification of laboratory bioassay procedures. Designed to evaluate the biological hazards of hazardous waste materials, the procedures resulted from an EPA sponsored workshop entitled, "Bioassessment of Hazardous Waste," held in Washington, D.C., October 26-27, 1981. The participants critically evaluated the available protocols that use biological testing to assess the risks from hazardous materials and identified those that would be applicable. PNL conducted a subsequent workshop entitled, "Field Validation of Hazardous Waste Bioassays," which was held in Denver, Colorado, March 30-31, 1982 (Appendix A). The purpose of the workshop was to evaluate proposed aquatic, terrestrial and microbiological field studies that could be used to validate the laboratory bioassay procedures identified in the first workshop. Participants at the Denver workshop also indicated that certain field bioassessment protocols should be developed that had no corresponding laboratory tests and could therefore stand alone as site assessment tools. Thus, the research conducted during FY 1982 and reported herein represents a selected set of the studies recommended by the Denver workshop participants.

Personnel from the Rocky Mountain Arsenal (RMA) indicated that they would cooperate on this study by making the Arsenal available as a field laboratory. Because of the unique history and the availability of some environmental data at RMA, the Arsenal was selected as the site to initiate field evaluations of the bioassessment procedures. 
Based on a proposed statement of work (Appendix B), a plan of six tasks was developed. Using the plan, PNL conducted and evaluated a series of multidisciplinary studies during FY 1982. At the conclusion of these studies, a revised plan was to be developed for Fy 1983.

The following research goals were to be addressed during FY 1982:

1. Determine the variability (both within and between laboratories) for the various bioassay procedures using contaminated soil samples from the Rocky Mountain Arsenal (RMA).

2. Assess variability within and between plots for several assessment techniques (for sampling small mammals, plants, insects including honeybees and microarthropods) so that field studies could be designed to detect a defined biotic change.

3. Establish three field plant transects which are apparently a) contaminated, b) appear contaminated and c) could serve as a control. Soil samples will be taken and subsequently subje:ted to bioassay if statistical analysis reveals a difference in plant communities.

4. Assess the feasibility (in the laboratory) of using Basin $F$ water to contaminate RMA soil artificially, and to supply information for the design of a field plot study in 1983 (See Statement of Work Appendix B).

5. Attempt to obtain preliminary data on any promising field or laboratory bioassessment techniques not currently menticoned in the statement of work.

6. Obtain field data to assess the ecological status of RMA lakes and compare these observations to results from bioassessment testing.

The complete FY 1982 project plan is included in Appendix C.

Based on the results of the studies discussed in this document, PNL will prepare a revised Project Plan. It appears, based on a review conducted in Richland (November 1982), that rather than conduct a sham field study at RMA (using Basin F water; see Appendix B) during 1983, a field study will be conducted to take advantage of the contamination already present in Basin $F$. Moreover, three laboratory bioassays and one field bioassessment procedure will receive research emphasis. 


\subsection{SITE SELECTION AND SOIL SAMPLING}

\subsection{SOILS FOR SEED GERMINATION AND SOIL MICROORGANISM BIOASSAYS}

\subsubsection{Introduction}

To carry out the recommendation that a planned hazardous waste site bioassessment study be conducted at the Rocky Mountain Arsenal, PNL researchers attempted to locate and sample a control site. Participants of the Denver workshop recommended field tests where test plots within the Rocky Mountain Arsenal would be subjected to various concentrations of contaminants from Basin F (a hazardous waste lagoon containing byproducts from nerve gas and pesticide production), or to contaminated ground water from well No. 26008. The response of two plant species (barley and red clover) and the metabolic rates of microorganisms within the treated soil were suggested as test parameters. The workshop participants proposed that these experiments be used to assess the feasibility of using similar bioassessment techniques for contaminated sites. They could be used as a means of determining the relative toxicity of hazardous waste sites as well. In addition, they could be used to test the effectiveness of rehabilitation projects at hazardous waste sites, and to correlate with laboratory bioassay studies conducted by Battelle's Columbus Laboratories (BCL) and EPA-Corvallis (CERL).

In preparation for the field experiment, we conducted a preliminary field excursion to locate a potential test site and collect a representative sample of the soil for laboratory studies. To mimic the proposed study to be carried out at the Arsenal during the summer of 1983, soils were treated with Basin $F$ or well water of various concentrations and the effects on microbial respiration and seed germination monitored (See Sections 7.0 and 8.0). These preliminary studies served as a dry run to investigate toxic or stimulatory properties of various treatment water concentrations, and to suggest any other problems that might arise in regard to the field experimental design. 


\subsubsection{Methods}

\section{Site Selection Criteria}

Just prior to the field trip to RMA, we learned that EPA may not allow soil amendments with Basin $F$ waters (RCRA regulations). Based on discussions with EPA at Corvallis, RMA personnel and scientists at Pacific Northwest Laboratory, we decided to proceed with site selection and soil sampling in the hope that EPA would grant a waiver by spring of 1983 and because this soil could be used as a control for bioassay development. Because we thought such a waiver likely, we selected a site where ground water flows into the groundwater containment and filtration barriers at the northern boundary of the Arsenal. We also decided to remove any contaminated soil to the Basin $F$ area after the study completion, if required, and to obtain soil analyses below the 6 in. plow layer to assess migration.

All of the sites that were available for our use had been contaminated. Based on soil data for Section 23 supplied by Dr. Bill Trautman of RMA (see Table 2.1), it appeared that either Section 23 or 24 might be the most logical choices. Since the contamination in those areas was principally from "moisture drift" from an experimental attempt to evaporate Basin F, it appeared that Section 24 would be less contaminated than Section 23 (even though no soil data were available) because prevailing winds are apparently more north than northeast.

We selected a site within Section 24, immediately east of the Air Force atmospheric monitoring station in that Section. The exact location of the southwest corner of the $200 \mathrm{ft} \times 200 \mathrm{ft}$ test site is $59 \mathrm{ft}$ from telephone pole \# 18, in a direction perpendicular to the section road. The test plot extends $200 \mathrm{ft}$ parallel to the road from this spot and $200 \mathrm{ft}$ away from the road. Red stakes were left at the site as corner markers. Each $50 \mathrm{ft} \times 50$ ft section was also staked.

\section{Representative Soil Sample}

Using a random sampling procedure, we chose thirty-nine of the possible $200 \mathrm{ft} \times 200 \mathrm{ft}=40,000 \mathrm{ft}^{2}$ within the test site for soil sampling. An area 
TABLE 2.1. Chemical Content of Soil in Section '23

\begin{tabular}{lll} 
& Compound & Range $(\mathrm{ppm}) \mathrm{n}=13$ \\
\cline { 2 - 2 } & Dieldrin & $0.07-0.03$ \\
Endrin & $0.002-0.02$ \\
Aldrin & Below detection \\
& Oxathiane & Below detection \\
& Dithiane & Below detection \\
(CPM02) & Chlorophenyl methyl sulfone & Below detection -0.11 \\
(DIMP) & Diisopropylmethyl phosphonate & 1 sample $=0.55$ \\
& Arsenic & 1 sample $=18$ \\
& Copper & 1 sample $=10$ \\
& Calcium & $2-72$ \\
& pH & $6-7.8$
\end{tabular}

(1) $\mathrm{A} 5200$ foot transect was taken across the midline of Section 23. In each 400 lineal portion, a 6 in. core was taken at $5 \mathrm{ft}$ intervals using an 0akfield corer (3/4" diameter). All cores were composited and mixed and one 500 to 600 gram sample taken for chemical analysis.

Thirteen (or 5200/400) samples were analyzed. Data supplied by Dr. Bill Trautman, Rocky Mountain Arsenal.

of 6 in. $x 6$ in. in the center of each of the one-foot squares was sampled to a depth of 6 in. below the top of the $A$ horizon.

Before sampling, all plant forms and organic matter within the 0 horizon were removed. Using a trowel with a 6 in. blade, the soil samples were transferred to a $3.0 \mathrm{mil}$ plastic garbage bag and subsequently transferred to trash barrels lined with garbage bags. The total wet weight of cans and samples was approximately $186 \mathrm{~kg}$. The samples were obtained on June 17 and shipped June 18. Upon receipt at PNL the soil was air dried and seived (1/4 in). Details for sampling are shown in Figure 2.1 and the site location is shown in Appendix D.

Field Observations

After soil sampling began in the proposed test plot, it became apparent that the most northern third of the sample plot contained only 4-6 in. of 


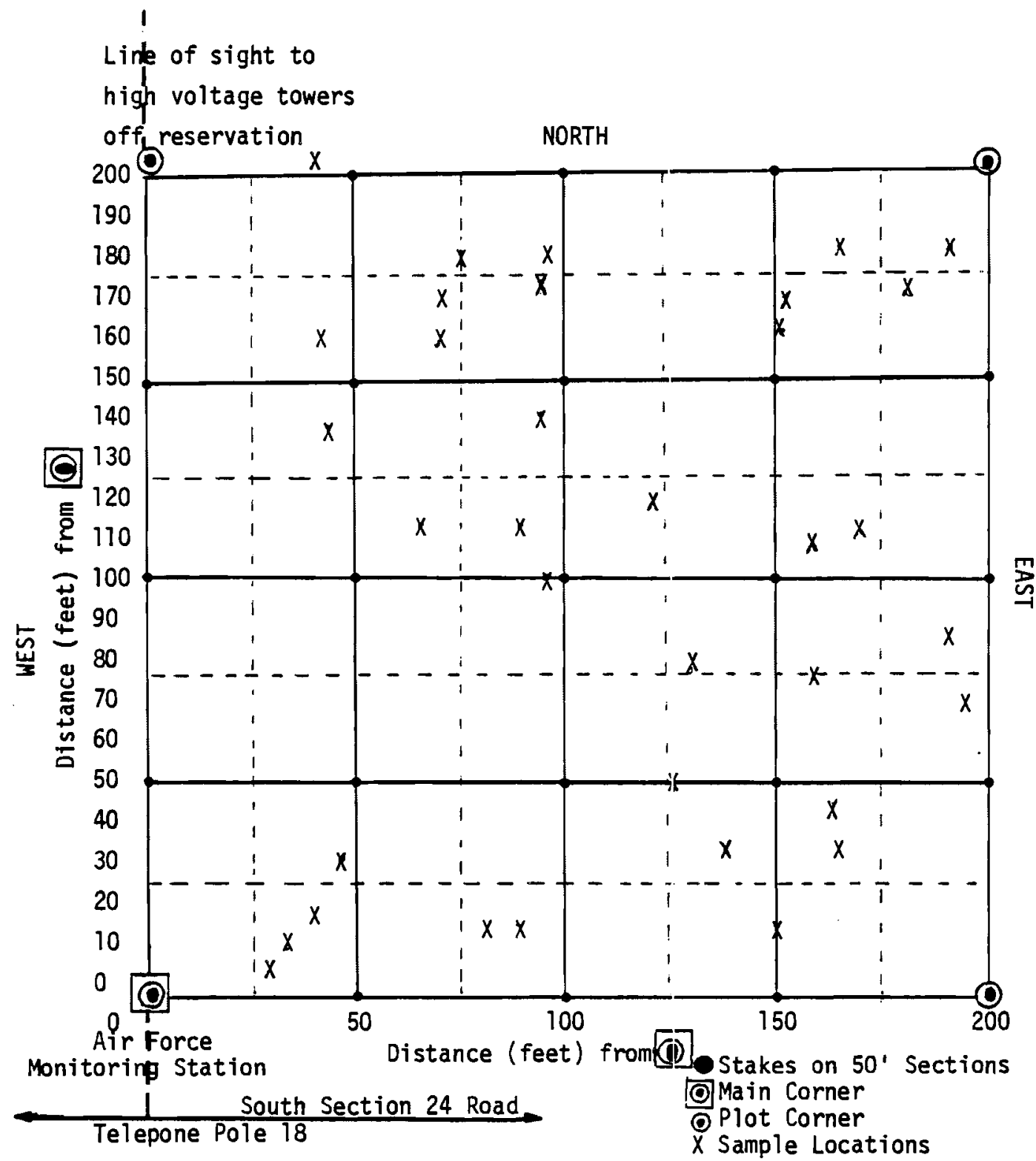

Sampling Procedures: Two sets of numbers were prepared from 0 through 20 . The first established an eastwardly direction at $10^{\prime}$ intervals. The second located a grid point in a northerly direction at $10^{\prime}$ intervals. The process was repeated where each number represented $0.5^{\prime}$ increments to locate a sampling point. The location (off the plot) came about because $2(1)$ was included (in error) in the first sequence.

FIGURE 2.1. Control Field Plot and Location of Random Soil Samples at RMA 
surface soil underlain by hard, packed sand. A survey of the plot (Figure 2.2) revealed a lack of perennial grasses not characteristic of vegetation observed on known uncontaminated sites during recent field surveys. In addition, it is possible that the soils in this area have been exposed to contaminated ground water from an unconfined aquifer or contaminants from the drift experiment.

\subsubsection{Results}

Even though some contamination may have occurred (Table 2.1), it appears that the plot would suffice for the proposed FY-1983 field study. Both the Neubauer (Section 8.0) plant studies and microbiological bioassays (Section 7.0) showed no adverse effect of the soil on seed germination and/or leaf length or on soil microbial performance.

\subsection{STATISTICAL ESTIMATION OF VARIANCES}

\subsubsection{Introduction}

A contaminated site was selected for soil sampling in June 1982 in order to allow us to assess the time needed to obtain laboratory bioassays from $\mathrm{BCL}$ and CERL, become aware of preparation and shipping problems, and to obtain variance estimates for each bioassay.

\subsubsection{Methods}

\section{Site Selection Criteria}

According to RMA personnel and available soil data, it appeared that obtaining a soil sample (evenly contaminated) which might induce a response via bioassay would be difficult. Samples containing sufficient contamination were artificial, lumped or high in salt (i.e., spoils from lakes, lime pits, or seeps in section 27 depressions). Accordingly, we sampled an old waste ditch leading to upper Derby Lake, since the presence of organic contaminants seemed likely there. Moreover, another contractor had just obtained soil cores in the area and some preliminary chemical analyses led us to believe we might find some bioassay effects (Table 2.2). 


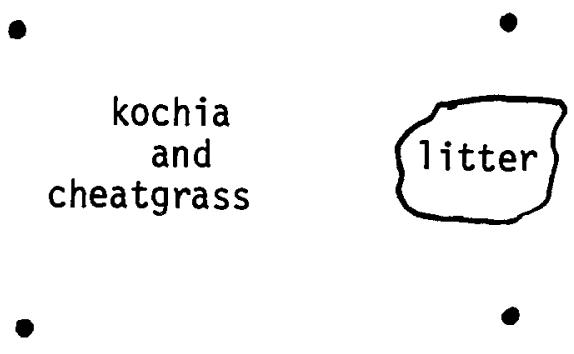

$$
\begin{aligned}
& \text { nearly } \\
& \text { uni formly } \\
& \text { kochia }
\end{aligned}
$$

$\bullet$

$N \backslash$

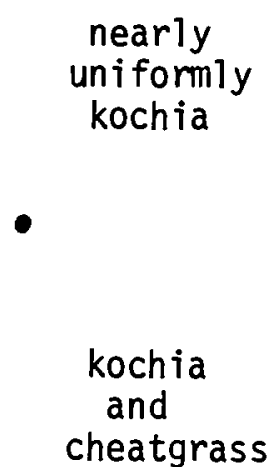

General Observations: 1) A very thick litter layer (cheatgrass straw?), 2) Only other species were tumbleweed, wild lettuce and two unknown forbs, 3) "Vigor" and phenology of existing vegetation variable, 4) Diversity, cover and phenology of vegetation towards road, 5) Probably seeded in crested wheatgrass at one time, 6) Skeleton of scme kind of mustard standing, 7) Very weedy - indicative of disturbance of some type.

FIGURE 2.2. Preliminary Map of Vegetation on the Control Soil Plot (Section 24: June 23, 1982) 
TABLE 2.2. Preliminary Soil Chemistry for Upper Derby Waste Trench

\begin{tabular}{|c|c|c|c|c|}
\hline \multirow[b]{3}{*}{ Substance } & \multicolumn{4}{|c|}{ Sample Number ${ }^{2}$} \\
\hline & \multicolumn{2}{|c|}{1} & \multicolumn{2}{|c|}{2} \\
\hline & $\underline{0-12^{\prime \prime}}$ & $\underline{12-24^{\prime \prime}}$ & $\underline{0-12^{\prime \prime}}$ & $\underline{12-24^{\prime \prime}}$ \\
\hline Aldrin & 0.038 & 0.74 & 29 & 103 \\
\hline Dieldrin & 0.260 & 0.075 & 3 & 96 \\
\hline Endrin & 0.034 & 0.015 & 0.33 & 0.33 \\
\hline Mercury & & & $(3.29$ & $3.41)^{1}$ \\
\hline
\end{tabular}

${ }^{1}$ Duplicate runs.

${ }^{2}$ Sample 1 was collected near the mouth and just to the right of the trench as it enters Upper Derby Lake. Sample 2 was collected in the lake bed after it had been drained. Results are in $\mathrm{mg} / \mathrm{kg}$ dry weight (or $\mathrm{ppm})$.

\section{Soil Samples}

We elected to sample from the bottom of a ditch, which at one time had drained the Shell chemical production facilities and terminated in the Upper Derby Lake Basin (in Section 1, near the mouth of the ditch; see Appendix D and Figure 2.3). This ditch received toxic wastes sporadically during the period from the beginning of operation of the chemical production facilities until 1965. Upper Derby Lake was drained in the fall of 1981; eventually, the contaminated sediments in the lake basin will be dredged and contained. The sample site was apparently submerged by the lake and probably contains sediments from Upper Derby Lake Basin. We sampled from the center of the drainage ditch $60 \mathrm{ft}$ beyond the tip of the remains of a concrete superstructure which extended into the ditch. The initial point, the center $(60 \mathrm{ft}$ up the ditch), and the $120 \mathrm{ft}$ point of the transect were all staked. We obtained a large soil sample from a $4 \mathrm{ft}$-wide corridor (two feet to each side of the transect) running parallel to the sides of the ditch and centered over the $60 \mathrm{ft}$ stake, to represent the soil of the bottom of the ditch. The soil was sampled to a depth of 6 in., equidistant from the center stake, until an 


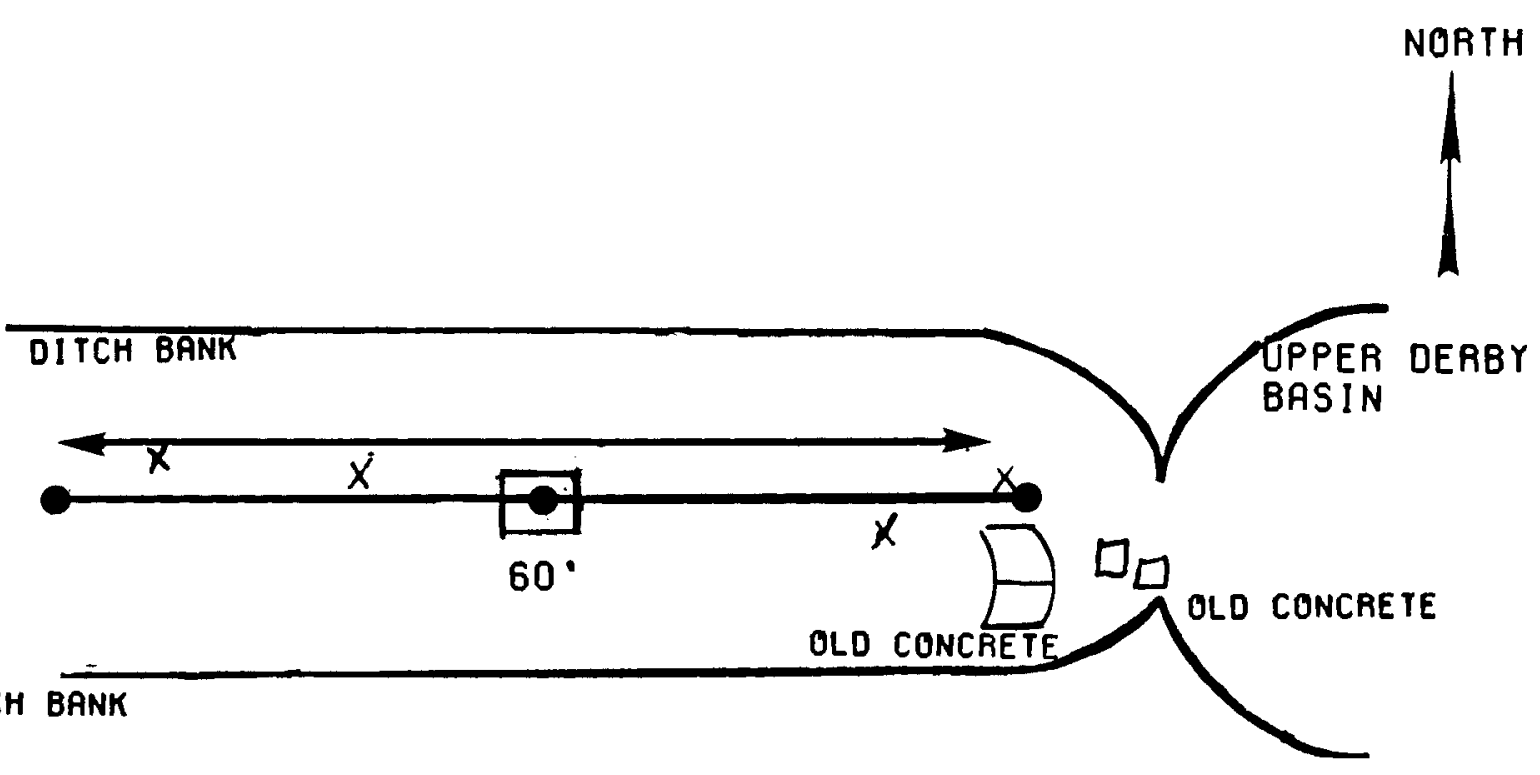

- Transect Stakes

$X$ Sample Location Stakes

FIGURE 2.3. Field Site and Sample Locations for Contaminated Soil in Section 1 
adequate volume of soil (approximately $180 \mathrm{~kg}$ ) was obtained. Additional random samples at other locations in the ditch were obtained for bioassay.

The random samples. were obtained by choosing a random number between 0 and 24 and measuring along the transect from the initial stake $(0 \mathrm{ft})$ to a point (i.e., 21 resulted in $105 \mathrm{ft}$ ), in units of five feet. We decided whether to move to the east or west of the transect by flipping a coin. An additional random number was drawn (between 0 and 6 ) to select a perpendicular distance ( 0 to $6 \mathrm{ft}$ in increments of $1 \mathrm{ft}$ ). A soil sample (15 in. $\times 15$ in. $\times 6$ in.) was obtained beginning nearest the inside edge of the transect. Four of the samples were obtained about 8 P.M., June 18, 1982, when it was discovered that some supplies had run out. Unfortunately, a heavy rain occurred overnight and well into June 19, and resulted in very muddy conditions. On the advice of PNL soil scientists we did not attempt to obtain further samples. Colleagues who remained at RMA to conduct small mammal studies obtained the large sample on June 21 ( $3 \mathrm{ft} \times 4 \mathrm{ft} \times 6$ in.). No further small samples were collected. The large sample was shipped June 22, 1982 (arrived June 29 in Richland), along with the four small samples. All samples were dried, sieved (1/4 in.) and suitably prepared for shipment to BCL and CERL for bioassay (Table 2.3).

\section{Field Observations}

Soil from the ditch bottom appeared to alternate between sediment and iron-rich sand layers. Few plants grew in the bottom, but vegetation density increased toward the edge (Figure 2.4). Later on in the year a lush plant growth was observed in the ditch bottom.

The four small samples ( $X$ in Figure 2.3) were sent to Battelle's Columbus Laboratories $(15.0 \mathrm{~kg}$ of each even though the draft protocol document indicated that only $7.5 \mathrm{~kg}$ was needed) for bioassay. The excess was sent to Corvallis (CERL) for selected bioassays. Our understanding was that CERL would run the Selanastrum, Daphnia and earthworm tests so that less than $7.5 \mathrm{~kg}$ of soil was needed. Battelle-Columbus was to run five tests (fathead, Selanastrum, Daphnia, seed germination/root elongation, and soil respiration); they needed $15 \mathrm{~kg}$ of material for these tests. The proposed protocol for bioassessment of hazardous waste sites (D.B. Porcella, Tetra 
TABLE 2.3. Sample Identification and Allocation to Obtain Variance Component Estimates for Bioassays, Soils and Laboratories

Randomly Selected Samples

\begin{tabular}{|c|c|c|c|c|c|}
\hline $\begin{array}{c}01 \mathrm{~d} \\
\text { Number }\end{array}$ & $\begin{array}{c}\text { New } \\
\text { Number }\end{array}$ & & $\begin{array}{l}01 \mathrm{~d} \\
\text { Number }\end{array}$ & $\begin{array}{c}\text { Ne:w } \\
\text { Number }\end{array}$ & \\
\hline $\begin{array}{r}\star B C L-1 \\
\star B C L-2 \\
* B C L-3 \\
* B C L-4 \\
\star * \star B C L-5\end{array}$ & $\begin{array}{l}\mathrm{BCL}-11 \\
\mathrm{BCL}-06 \\
\mathrm{BCL}-02 \\
\mathrm{BCL}-09 \\
\mathrm{BCL}-5\end{array}$ & $\begin{array}{l}15 \mathrm{~kg} \\
15 \mathrm{~kg} \\
15 \mathrm{~kg} \\
15 \mathrm{~kg} \\
15 \mathrm{~kg}\end{array}$ & $\begin{array}{l}\text { COR-1 } \\
\text { COR-2 } \\
\text { COR-3 } \\
\text { COR-4 } \\
\text { COR-5 }\end{array}$ & $\begin{array}{l}\text { COF:-11 } \\
\text { COF:-06 } \\
\text { COF:-02 } \\
\text { COF:-09 } \\
\text { COF:-05 }\end{array}$ & $\begin{array}{l}\text { Extra soil }=0.00 \mathrm{~kg} \\
\text { Extra soi }=5.75 \mathrm{~kg} \\
\text { Extra soi } 1=2.75 \mathrm{~kg} \\
\text { Extra soil }=2.75 \mathrm{~kg} \\
5.0 \mathrm{~kg}\end{array}$ \\
\hline $\begin{array}{l}* \star \mathrm{BCCL}-6 \\
\star \star \mathrm{BCL}-7 \\
\star \star \mathrm{BCL}-8 \\
\star \star \mathrm{BCL}-9 \\
\star \star \mathrm{BCL}-10 \\
\star \star \mathrm{BCL}-11 \\
\star \star \mathrm{BCL}-\text { Practic }\end{array}$ & $\begin{array}{l}B C L-04 \\
B C L-10 \\
B C L-08 \\
B C L-03 \\
B C L-01 \\
B C L-07 \\
c e\end{array}$ & $\left.\begin{array}{rl}15 & \mathrm{~kg} \\
15 & \mathrm{~kg}\end{array}\right\} 30$ & $\begin{array}{l}\text { COR-6 } \\
\text { COR-7 } \\
\text { COR-8 } \\
\text { COR-9 } \\
\text { COR-10 } \\
\text { COR-11 } \\
\text { COR-Practice }\end{array}$ & $\begin{array}{l}\text { COF }-04 \\
\text { COF }-10 \\
\text { COF }-08 \\
\text { COF }-03 \\
\text { COF }-01 \\
\text { COF }-07\end{array}$ & 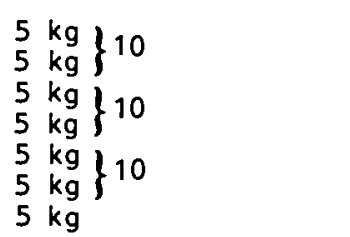 \\
\hline
\end{tabular}

*Small samples; See Figure 1.3.

**Large soil sample $(180 \mathrm{~kg}$ dried,

seived (1/4 in.), and mixed).

3 - $30 \mathrm{~kg}$ subsamples mixed separately

3 - $10 \mathrm{~kg}$ subsamples mixed separately each sample divided equally after

1 - $20 \mathrm{~kg}$ subsample mixed separately mixing

1 - $10 \mathrm{~kg}$ subsample mixed separately

Tech) indicates that three random soil samples will be used from three areas of individual sites in a screening mode. It is our intent that the four random samples mimic that situation for the "core (most impacted) station" (page 41, draft protocol document), so that an estimate of the variance among samples at the same place can be obtained for each bioassay. This area, though, might be larger than that envisioned in the Porcella document. In addition, we constructed another small sample (*,**, Table 2.3$)$ so that a total of five were available to estimate the variance at a location.

The large sample (approximately $180 \mathrm{~kg}$.) was used to obtain estimates of the laboratory variance (i.e. CERL versus $B C L * \star$, Table 2.3) for each bioassay. Subsamples of various sizes (Table 2.3) were mixed and divided into the fractions indicated in the table. This system allowed comparisons between Battelle-Columbus and Corvallis for two of the bioassays (Selanastmum and Daphnia) and a "practice" sample for each laboratory. Since some investigators were concerned that the "trench" sample might be high in salt, conductivity measurements were made. Conductivity values were $1600,100,80$ 
Top_of Bank 0

Cottonwood, rush, mullein, willow

Mostly bare, a few cottonwood and willow seedlings

Buttercup and one other known forb

$\mathrm{N}$

Some bare spots, tumbleweed, wild lettuce, orchard grass, ragweed, several unidentifiable forbs.

Mostly buttercup and one other unknown forb

Sweet clover, willow, cottonwood, wild barley

Cottenwood, rush, mullein, willow, wild barley

Top of Bank $\triangle$

FIGURE 2.4. Vegetation at the Ditch Soil Sampling Site Section 1, June 23, 1982 
$\mu /$ mole for the trench, section 24 and a Hanford control soil, respectively. Even though the contaminated sample appeared to exhibit a high conductivity $(1600 \mu / m o l e)$, PNL experience with Colorado soils indicates that this value is not exceptional.

\subsubsection{Results}

Preliminary chemical analysis and bioassay results from Battelle's Columbus Laboratories are shown in Table 2.4. Clearly the pesticide values obtained were not as high as expected based on those in Table 2.2. However, we note that the cores in Table 2.2 were obtained at depths to $24 \mathrm{in}$. compared to our samples, which were obtained from $0-6$ in. It is not unreasonable to expect that migration to lower depths occurred since the ditch was last used (1965). Even though the contaminants present did not produce toxicity (defined as an LC/LD 50 levels), we have recorded the results obtained by $\mathrm{BCL}$ for selected bioassays at the bottom of Table 2.4. We note here that if it is assumed that the density of trench soil is between 1.25 and $3.00 \mathrm{~g} / \mathrm{cm}^{3}$ and the plow layer is $6 \mathrm{in.,} 10 \mathrm{ppm}$ of a pesticide in soil would result from applications between 17 to $41 \mathrm{~kg} / \mathrm{acre}$. This range is over the the State of Washington limit for Endrin (2 1b/acre) and may have implications for bioassay sensitivity at hazardous waste site boundaries.

Since bioassay results from the Corvali is laboratory are not available at this time, we could not perform an interlaboratory comparison. However, using the data in Table 2.4 and a nested analysis of variance (starred samples only) we ascertained that the subsampling variance within split samples (e.g. 4 and 10, 8 and 3 , and 1 and 7 ) was larger than that because the samples which they obtained were larger. Moreover, no significant differences were observed between mean values for the starred samples (subsamples of the large sample; see Table 2.4) and sanples from other areas of the trench for any bioassay. Thus, we pooled all sample data for each bioassay and estimated their respective variances. Resulting coefficients of variation were on the order of 20,6, and 14 percent for the Selenastrum, lettuce and clover assays respectively. Since LC/LD-50 values could not be estimated, we could not ascertain whether those values would be less variable. 
TABLE 2.4. Results of Battel le Columbus Laboratories Chemical Analyses for Pesticides and Selected Bioassays of Upper Derby Trench Soil $(\mu \mathrm{g} / \mathrm{g})^{1}$

\begin{tabular}{|c|c|c|c|c|c|c|c|c|c|c|c|}
\hline & & & & & * & & & & & & \\
\hline Compound** & 11 & 6 & 9 & 2 & 5 & 4 & $\underline{10}$ & 8 & 3 & 1 & 7 \\
\hline Lindane & ND & ND & ND & ND & .05 & ND & ND & ND & ND & ND & ND \\
\hline B BHC & 0.1 & 0.1 & 0.1 & 0.1 & ND & ND & 0.1 & ND & ND & ND & ND \\
\hline$\triangle B H C$ & 0.2 & 0.2 & 0.1 & ND & ND & ND & 0.1 & ND & ND & ND & ND \\
\hline Heptachlor & 1.6 & 0.6 & 9.3 & 0.8 & 3.3 & 2.4 & 3.1 & 3.5 & 2.6 & 1.5 & 2.9 \\
\hline Dieldrin & 0.4 & 0.1 & 0.9 & 0.1 & 0.9 & 0.8 & 0.8 & 0.8 & 0.8 & 0.4 & 0.8 \\
\hline Endrin & 0.3 & ND & 0.4 & -- & 0.2 & 0.2 & 0.2 & 0.2 & 0.2 & 0.1 & 0.2 \\
\hline$p, p^{\prime}-D D E$ & 0.1 & 0.1 & 0.2 & 0.1 & 0.2 & 0.2 & 0.2 & 0.1 & 0.1 & 0.1 & 0.2 \\
\hline 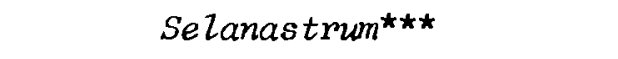 & 63 & 92 & 97 & 77 & 58 & -- & 69 & 72 & 63 & 83 & 50 \\
\hline Clover germination $(\%)$ & 80 & 80 & 80 & 60 & 67 & 60 & 60 & 87 & 60 & 67 & 80 \\
\hline Lettuce germination (\%) & 100 & 80 & 93 & 100 & 93 & 93 & 93 & 93 & 87 & 93 & 93 \\
\hline $\begin{array}{l}\text { *Large trench sample; } \\
\star_{\alpha B C H} \text {, Aldrin, Heptach } \\
\text { detectable" at a } 0.0\end{array}$ & $\begin{array}{l}\text { pai } \\
\text { hor } \\
5 \mu g\end{array}$ & $\begin{array}{l}\text { vere s } \\
\text { xide, } \\
\text { detect }\end{array}$ & $\begin{array}{l}t \text { of } \\
\operatorname{limi}\end{array}$ & $\begin{array}{l}\text { le su } \\
, p^{\prime} D\end{array}$ & $\begin{array}{l}\text { le, } \\
\text { ndr }\end{array}$ & $\begin{array}{l}\text { ample } \\
\text { Alde }\end{array}$ & $\begin{array}{l}\text { mber } \\
\text { le an }\end{array}$ & $\begin{array}{l}\text { coinc } \\
\text { Endos }\end{array}$ & $\begin{array}{l}\text { wit } \\
\text { fan S }\end{array}$ & $\begin{array}{l}\text { Table } \\
\text { fate }\end{array}$ & $\begin{array}{l}3 . \\
\text { e "not }\end{array}$ \\
\hline $\begin{array}{l}\text { **Percent of control } \\
\text { germination were } 76 \\
1 \text { Data taken from Duke, } \\
\text { Terrestrial and Aquatic } \\
\text { Contract } 68-02-3682 \text {. }\end{array}$ & $\begin{array}{l}\text { tand } \\
\text { and } 1 \\
\text { K.M., } \\
\text { c Bio } \\
22 \text { p. }\end{array}$ & $\begin{array}{l}\text { crop } \\
\text { o resp } \\
\text { J. Be } \\
\text { says }\end{array}$ & $\begin{array}{l}80 \% \\
\text { ively } \\
\text { and } N \\
\text { lazarc }\end{array}$ & $\begin{array}{l}\text { sure } \\
100 \% \\
\text { Mill } \\
\text { Wast }\end{array}$ & $\begin{array}{l}\text { late } \\
\text { Nov } \\
\text { tes }\end{array}$ & $\begin{array}{l}\text { tion. } \\
\text { oncent } \\
\text { ber } 24 \\
\text { Batte }\end{array}$ & $\begin{array}{l}\text { Contr } \\
\text { tion } \\
1982 \\
\text { e, C }\end{array}$ & clor & & ttuce & \\
\hline
\end{tabular}


Because we observed no significant bioassay differences as a result of where and how the samples were obtained, we plotted the mean result of all three bioassays (for each sample) as a function $0=$ both total pesticide concentration and heptachlor alone. Even though we observed an apparent relationship (i.e. lower viability as concentration increases) for both total pesticide and heptachlor alone, we elected not to present the figure here because so few samples were available and because two data points were apparently outliers. However, we suggest that the relationship be reexamined when the Corvallis bioassay data become available.

\subsection{INTERLABORATORY COMPARISONS}

\subsubsection{Introduction}

Because the contaminated soils discussed in the previous section did not induce appreciable toxicity based on laboratory bioassays, an additional field trip was conducted to RMA on October 21, 1982 (in conjunction with EPA personnel) to collect additional soil samples. In addition, because of speculation that contamination may have migrated below six inches in the upper Derby Trench (see Section 2.3.3) as well as in Basin C (see Sections 5.0 and 8.0) and Basin A, samples were collected as a function of soil depth.

\subsubsection{Methods}

The main emphasis was in Basin A (Section 36) because an EPA soil sample collected in 1981 (EPA085) suggested that a drainage area was significantally contaminated (See Appendix D for the location). Basin A samples were collected to assess inter- and intra- laboratory variability. The approximate location of Basin A samples are shown in Figure 2.5, the Upper Derby sample is shown in Figure 2.6, and the Basin $C$ sample is in Figure 2.7. Additional samples selected from the "control area" (Section 24, Appendix D) are shown in Figure 2.8. These samples were selected to supply additional soil for Fy83 laboratory studies. A11 samples (except those in Section 24) were taken using a standard shovel. Those in Section 24 were selected as described in Section 2.1.2. Samples are identified in Table 2.5.

\subsubsection{Results}

Samples are now being prepared for bioassay. 


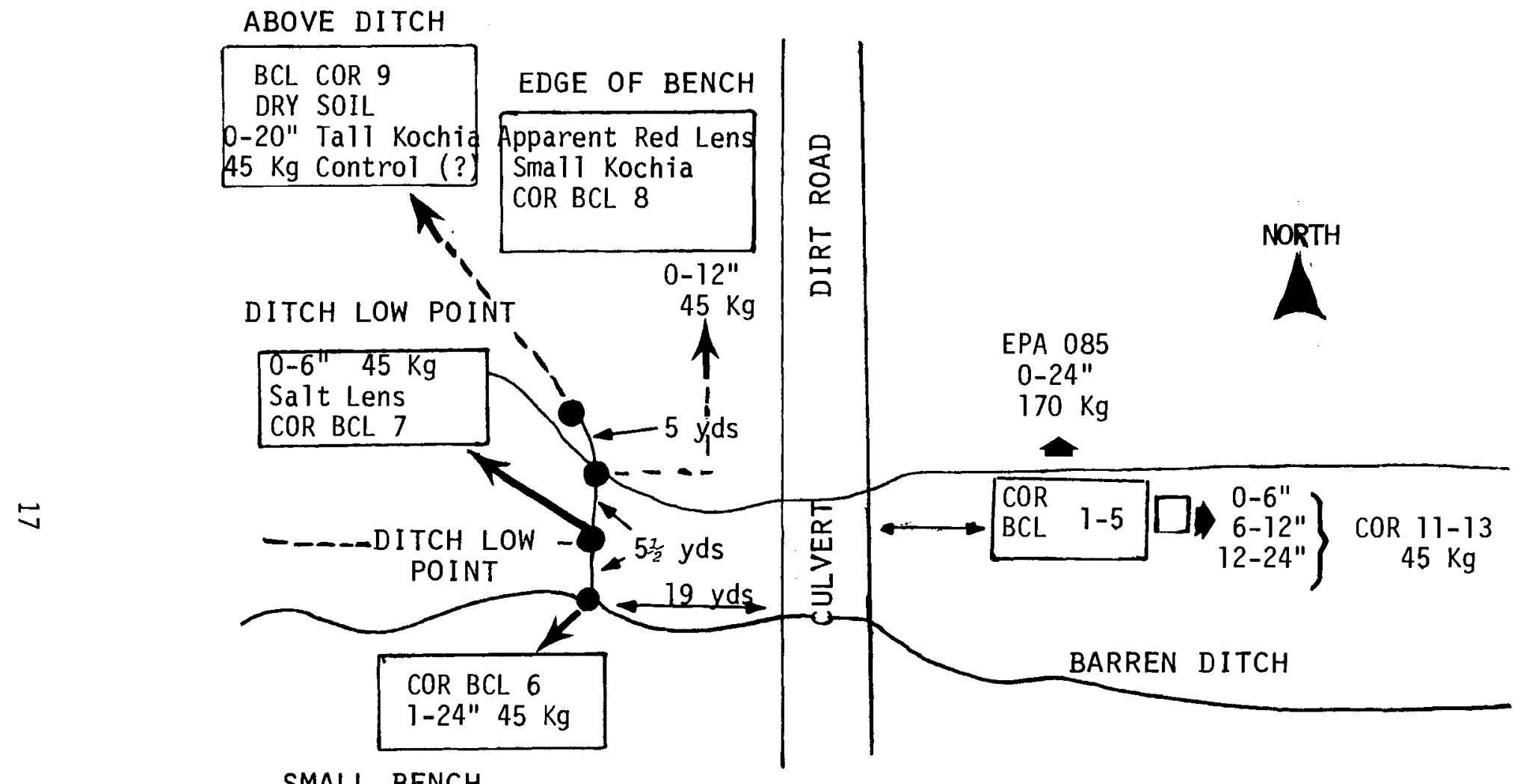

SMALL BENCH

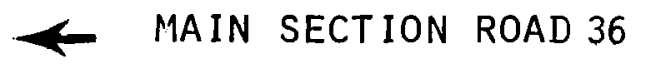

FIGURE 2.5. Approximate Location of Soil Samples Taken in Basin A 


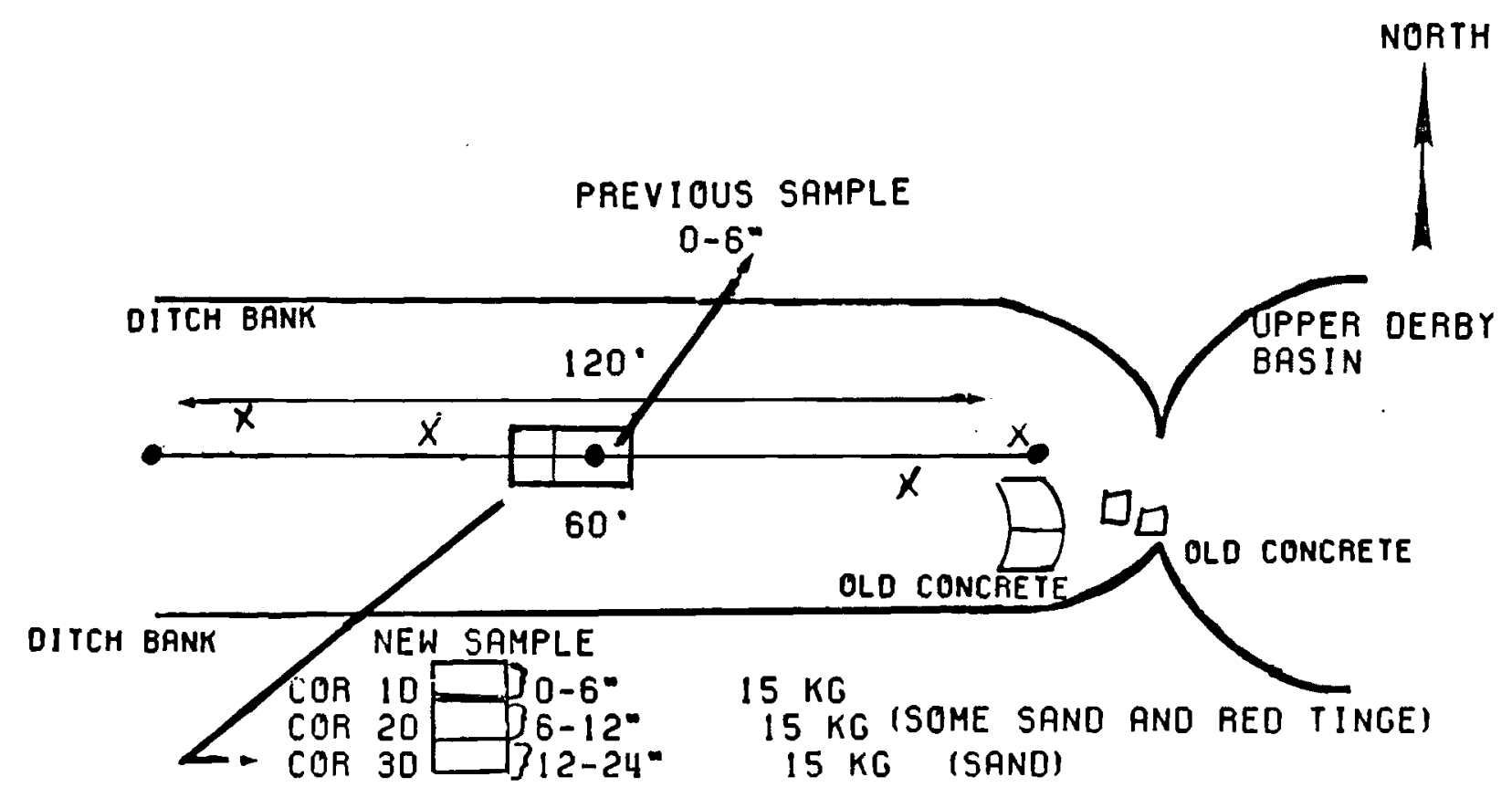

- transect stakes

FIGURE 2.6. Location of Vertical Soil Samples Taken Near the Mouth of Ditch and Upper Derby Lake 


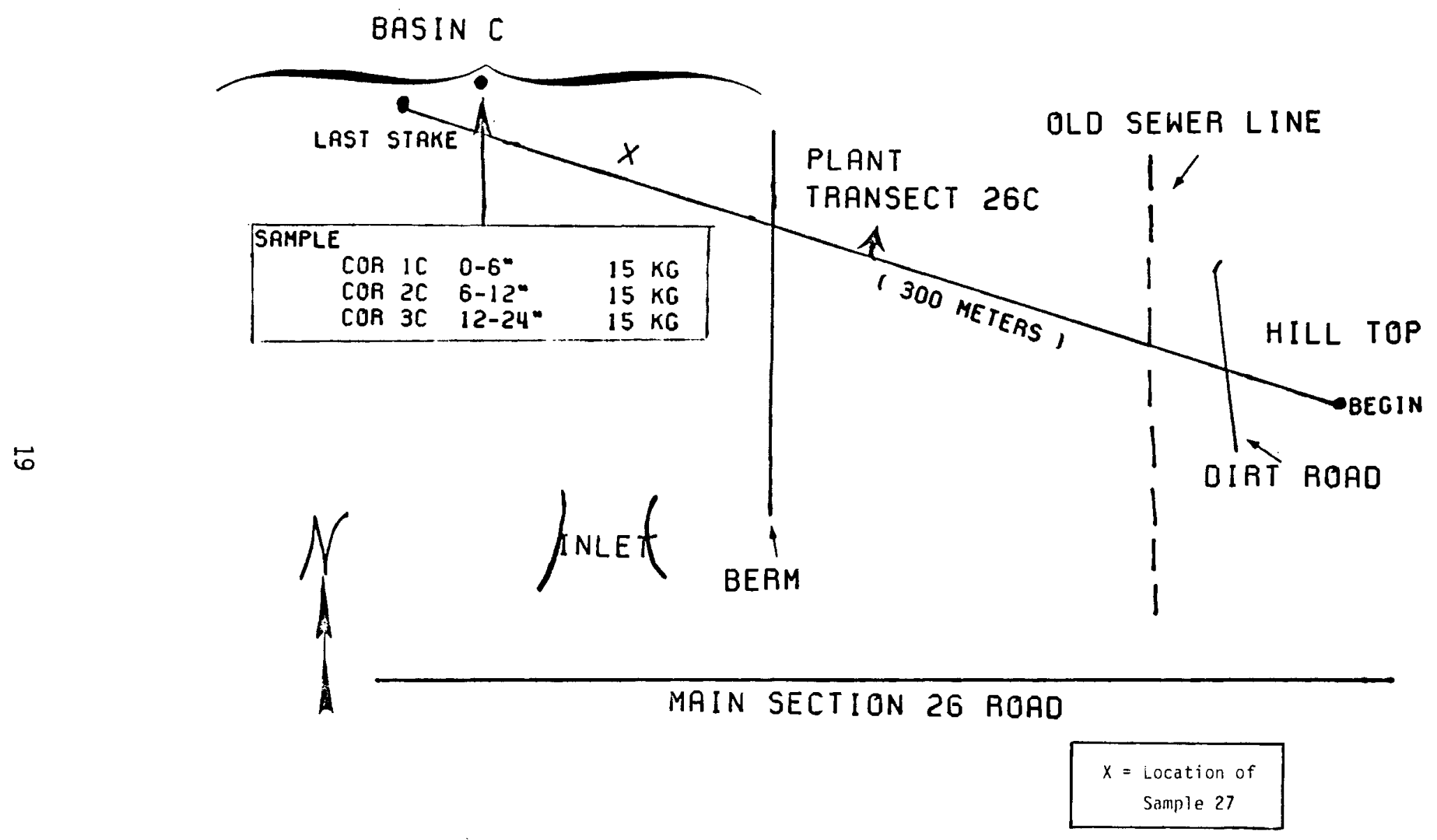

FIGURE 2.7. Location of Vertical Soil Sample Taken in Basin C 


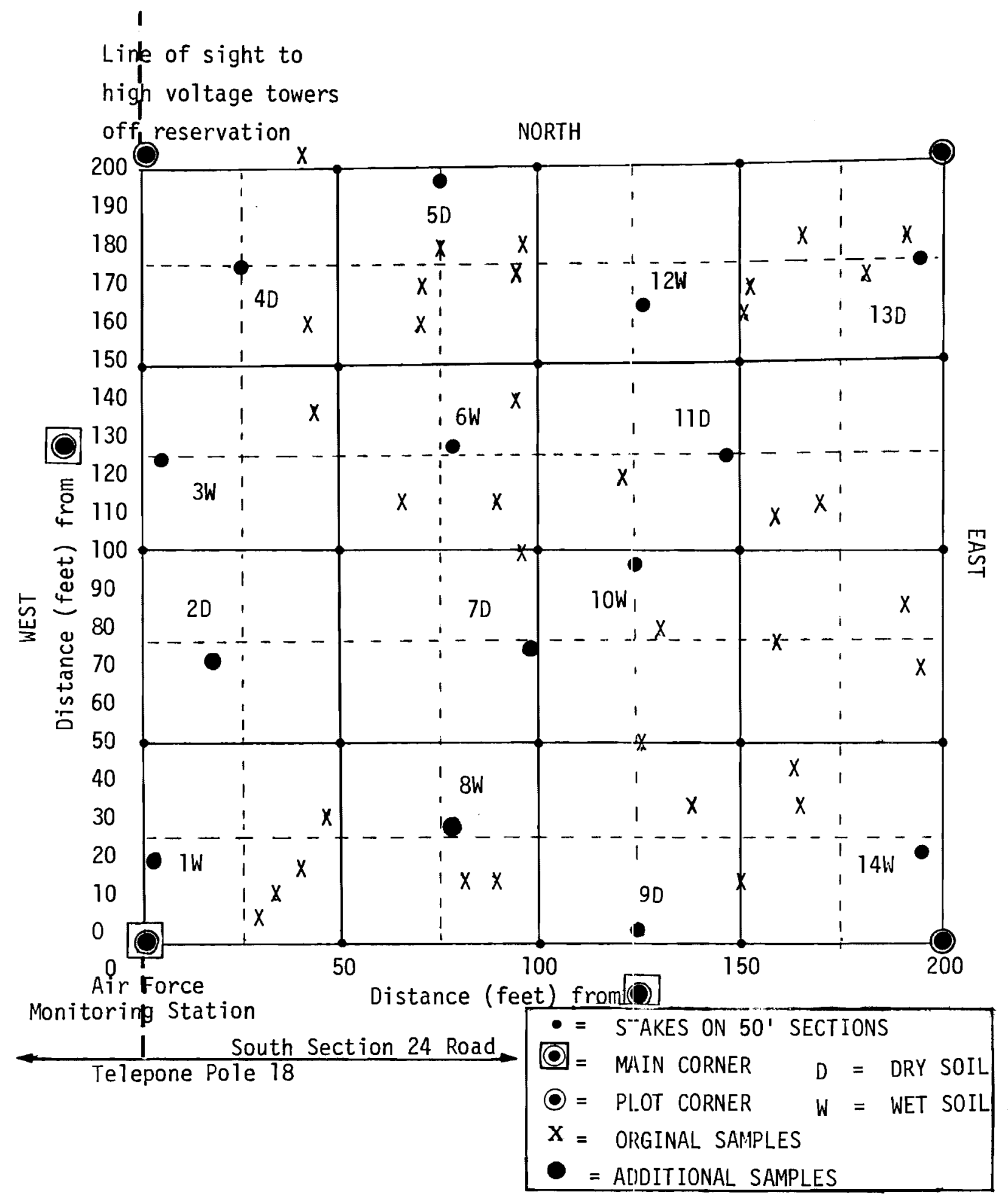

FIGURE 2.8. Control Field Plot Located in Section 24 and Location of Additional Samples (October 22, 1982) 
TABLE 2.5. Identification of Soil Samples Collected 10/21/82 at RMA

\begin{tabular}{|c|c|c|c|c|}
\hline Location & Sample Numbers & How Collected & What Next & Ultimate \\
\hline $\begin{array}{l}\text { Basin } A \\
\text { (Lab comparison) }\end{array}$ & COR BCL $1-5 A$ & $\begin{array}{l}4 \text { Garbage Cans } \\
0-6,6-12,12-18,18-24^{\prime \prime} \\
\text { About } 45 \mathrm{~kg} / \mathrm{can}\end{array}$ & $\begin{array}{l}\text { Dry } \& \text { mix } \\
\text { all soil }\end{array}$ & $\begin{array}{l}10 \text { (15) kg samples* } \\
5 \text { for Cor } 1-5 A \\
5 \text { for BCL } 1-5 A\end{array}$ \\
\hline $\begin{array}{l}\text { Basin } A \\
\text { Gradient Comparison }\end{array}$ & COR BCL 6-9A & 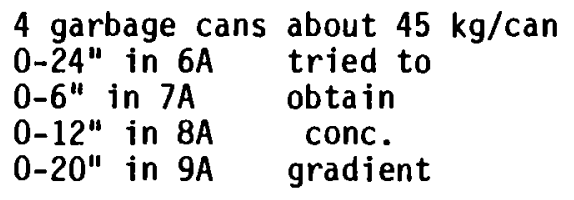 & $\begin{array}{l}\text { Dry } \operatorname{mix} \\
\text { individual } \\
\text { garbage } \\
\text { cans }\end{array}$ & $\begin{array}{l}\text { 2(15) kg samples of each } \\
\text { i.e. }-4 \text { to COR } 6-9 A \\
4 \text { to BCL } 6-9 A\end{array}$ \\
\hline $\begin{array}{l}\text { Basin A } \\
\text { Vertical } \\
\text { Study }\end{array}$ & COR 11-13A & $\begin{array}{ll}1 \text { garbage } & \text { can about } 60 \mathrm{~kg} \\
0-6^{\prime \prime} & \text { Bagged } \\
6^{\prime \prime}-12^{\prime \prime} & \text { Individually } \\
12^{\prime \prime}-24^{\prime \prime} & 20 \mathrm{~kg} / \mathrm{bag}\end{array}$ & $\begin{array}{l}\text { Dry mix } \\
\text { each level } \\
\text { individually }\end{array}$ & $\begin{array}{l}3(15) \mathrm{kg} \text { samples } \\
\text { for COR } \\
\text { i.e. COR 11-13A }\end{array}$ \\
\hline $\begin{array}{l}\text { Basin C } \\
\text { Vertical } \\
\text { Study }\end{array}$ & $\operatorname{COR} 1-3 \mathrm{C}$ & $\begin{array}{ll}1 \text { garbage } & \text { can about } 60 \mathrm{~kg} \\
0-6 & \text { Bagged } \\
6^{\prime \prime}-12^{\prime \prime} & \text { individually } \\
12^{\prime \prime}-24^{\prime \prime} & 20 \mathrm{~kg} / \mathrm{bag}\end{array}$ & $\begin{array}{l}\text { Dry \& mix } \\
\text { each level } \\
\text { individually }\end{array}$ & $\begin{array}{l}3(15) \mathrm{kg} \text { samples } \\
\text { for COR } \\
\text { i.e. COR } 1-3 C\end{array}$ \\
\hline $\begin{array}{l}\text { Upper Derby Lake } \\
\text { Vertical } \\
\text { Study }\end{array}$ & COR 1-3 D & 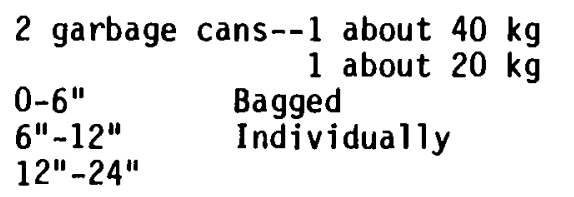 & $\begin{array}{l}\text { Dry \& mix } \\
\text { each level } \\
\text { individually }\end{array}$ & $\begin{array}{l}3(15) \mathrm{kg} \text { samples } \\
\text { for COR } \\
\text { i.e. COR } 1-30\end{array}$ \\
\hline
\end{tabular}

*0nly three samples will be subjected to bioassay by Battelle Columbus (BCL), all five by the Corvallis EPA Laboratory (COR). 

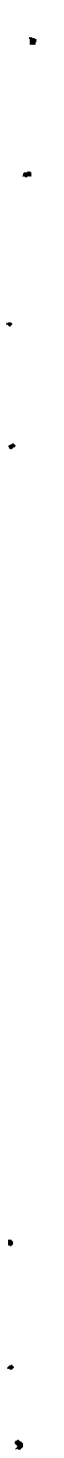


\subsection{FRESHWATER STUDIES}

\subsection{INTRODUCTION}

The Aquatic Panel of the 1982 Denver Workshop discussed approaches and indices pertinent to fulfilling the aims of the aquatic studies. The goal was to examine field impacts to the aquatic ecosystems at RMA. Priorities were established for different indices and it was generally agreed that site specific characteristics would dictate actual usage.

Evaluating the measurements was a significant problem. What, for example, should the biological measurements from the potentially impacted ecosystems be compared with? Two "best" approaches were considered: 1) historical, "pre-impact" data from the RMA lakes themselves, or 2) use of a nearby "control" lake. We discovered quickly that sufficient historical data were not available for the RMA lakes and that the best approach was to search for a suitable "control" lake and supplement data from it with pertinent literature data. Though the Aquatic Panel recognized that the probability of finding an nonimpacted lake in the vicinity of the Denver Metropolitan area was unlikely, they recommended that, lacking other comparative data, a search be made.

To this end, scientists in the Denver area who might suggest potential sites were contacted. In July, 1982, a field trip to Denver was conducted to select and to sample three candidate "control" lakes and sample the two RMA lakes, Mary and Ladora, to determine the feasibility of this approach. Water samples were also to be collected from the RMA lakes to be sent to BattelleColumbus for a series of bioassays.

\subsection{METHODS}

In selecting lakes for study, we held interviews and discussions with personnel from the Colorado Division of Wildlife (DOW), Harner-White Ecological Consultants, and the U.S. Fish and Wildi ife Service (F\&WS). The DOW furnished a publication prepared by their metro biologist which summarized data from essentially all lakes in the Denver area as well as providing diagrams, locations, etc. on each. The F\&WS has been sampling the fish at 
the RMA lakes regularly for several years and provided all their data to date. The DOW also provided historical data on the fish populations of the three candidate control lakes.

From these sources and their suggestions, Berkeley Lake, Rocky Mountain Lake, and Crown Hill Lake (Figure 3.1) were selected as the best potential candidates. A suggestion from the Harner-White ecologists to consider emergency, "protected" water supply lakes owned by the Denver Water Board was not pursued because of labor and time constraints.

Physical, chemical, and biological data were collected on all five lakes. The field and laboratory methods used for analyses are presented in Table 3.1.

\subsection{RESULTS}

Berkeley and Rocky Mountain Lakes are owned by the Denver Park Board; each are located within small, city parks. No bozting is allowed, although fishing from shore is permitted. Both lakes are quite turbid. Crown Hill Lake is used for irrigation of the Crown Hill Cemetery. Fishing, but not boating, is allowed. It, too, is turbid, with dense rush and cattail beds around most of the shoreline.

In contrast to Berkeley, Rocky Mountain, and Crown Hill lakes, both Mary and Ladora are quite clear. The bottom is clearly visible in Mary; depth is about $2 \mathrm{~m}$. Mary is extremely weed-choked with aquatic macrophytes (two species of Potomogeton). Ladora is similarly filled with macrophytes, but because of its greater size and depth $(3 \mathrm{~m})$, it contains considerably more open water in the middle.

No physical or chemical differences were detected which could be attributed to RMA impacts (Table 3.2). In the table, means for three measurements taken at the surface, mid-depth, and near-bistom are presented. Water temperatures were similar (within $2^{\circ}$ of each other) in all lakes. At the RMA lakes, $\mathrm{pH}$ was highest at the time of sampling, but historical data for these lakes show that they are frequently in the $\mathrm{pH} 8-9$ region. Though no data on 


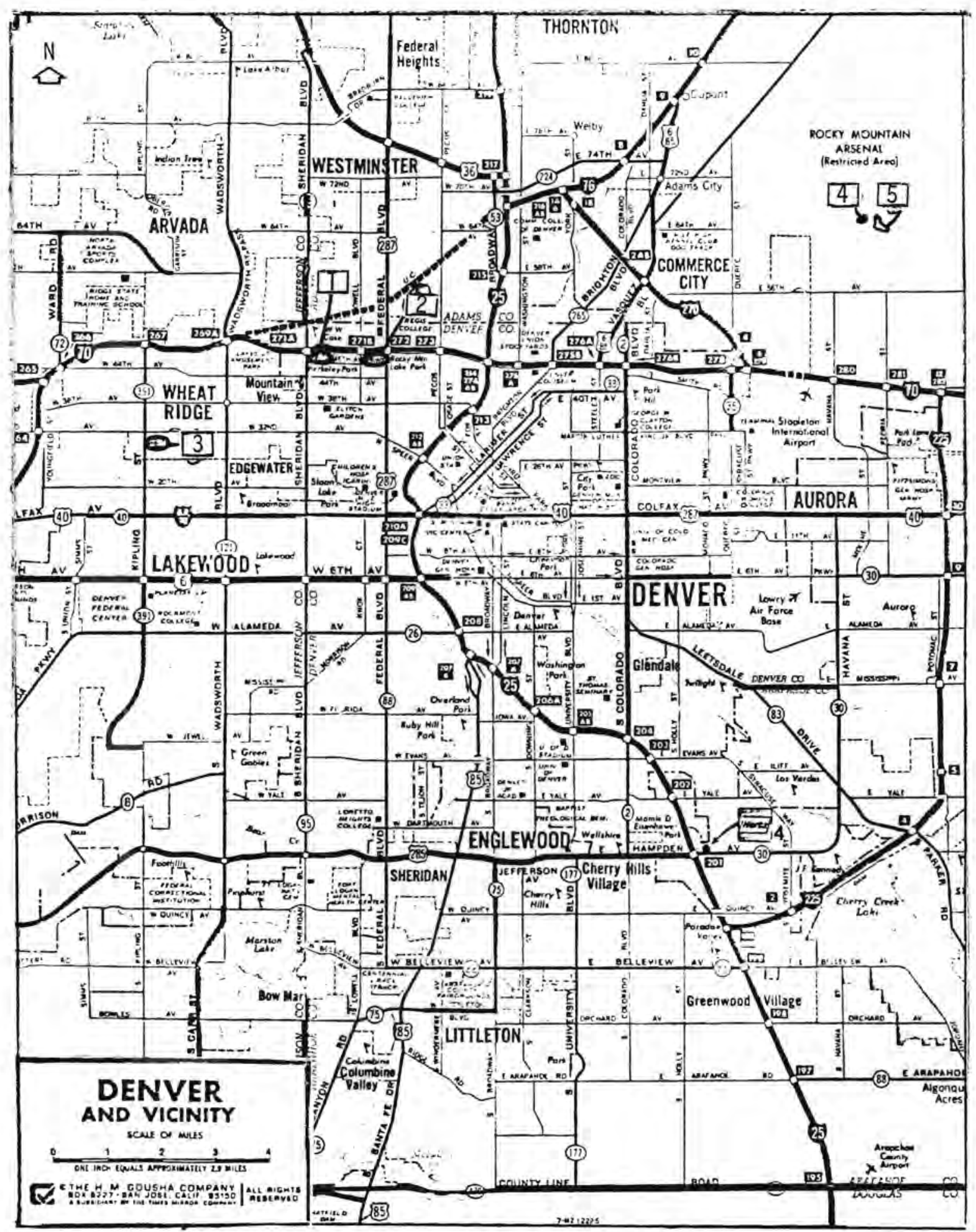

FIGURE 3.1. Study lakes in the Denver Area: (1) Berkeley, (2) Rocky Mountain, (3) Crown Hill, (4) Mary, (5) Ladora 
TABLE 3.1. Chemical, Physical, and Biological Data Collection and Analysis Methods Used for Denver Area and RMA Lakes

Field Measurements

\begin{tabular}{|c|c|c|}
\hline Measurement & Location & Instrument \\
\hline $\begin{array}{l}\text { Temperature } \\
\mathrm{pH}\end{array}$ & $\begin{array}{c}\text { Surface, mid, bottom;mid-lake } \\
\text { " }\end{array}$ & $\begin{array}{l}\text { YSI electronic thermometer } \\
\text { Hach colorimeter }\end{array}$ \\
\hline Dissolved oxygen & " & YSI electronic probe \\
\hline \multicolumn{3}{|l|}{ Phytoplankton } \\
\hline Biomass & $"$ & 3e VanDorn bott1e; \#20 net \\
\hline Chlorophy11 & $"$ & Filtered samples \\
\hline Qualitative & mid-lake & Vertical hau1, \#20 net \\
\hline \multicolumn{3}{|l|}{ Zooplankton } \\
\hline Biomass & Surface, mid, bottom;mid-1ake & 3e VanDorn bottle; \#10 net \\
\hline Qualitative & mid-lake & Surface tow, \#10 net \\
\hline Bottom fauna & Transect, mid-lake to shore & Ekman dredge, sieves \\
\hline \multicolumn{3}{|c|}{ Laboratory Measurements } \\
\hline Measurement & \multicolumn{2}{|r|}{ Method } \\
\hline \multicolumn{3}{|l|}{ Phytoplankton } \\
\hline Biomass & \multicolumn{2}{|c|}{$\begin{array}{l}\text { Oven dry at } 105^{\circ} \mathrm{C} \text {; ash at } 450^{\circ} \mathrm{C} \text {, dry wt, ash } \\
\text { free dry wt }\end{array}$} \\
\hline Chlorophyl1 & \multirow{2}{*}{\multicolumn{2}{|c|}{$\begin{array}{l}\text { Acetone extraction, fluorometric determination } \\
\text { Microscopic identification }\end{array}$}} \\
\hline Qualitative & & \\
\hline Bottom fauna & \multicolumn{2}{|c|}{ Microscopic identification } \\
\hline Fish & \multicolumn{2}{|c|}{ Calculation of $\mathrm{K}$ factors } \\
\hline
\end{tabular}


TABLE 3.2. Physical-Chemical Data, (Mean of Three Samples) Obtained at Denver Area and RMA Lakes

\begin{tabular}{|c|c|c|c|}
\hline Lake & $\mathrm{pH}$ & $\begin{array}{c}\text { Temperature } \\
\left({ }^{\circ} \mathrm{C}\right) \\
\end{array}$ & Dissolved Oxygen \\
\hline Berkeley & $9.5+$ & 19.9 & 11.2 \\
\hline Rocky Mountain & 8.8 & 20.7 & 9.1 \\
\hline Crown Hill & 8.4 & 20.6 & 7.8 \\
\hline Mary & $10+$ & 20.0 & - \\
\hline Ladora & $10+$ & 21.8 & - \\
\hline
\end{tabular}

dissolved oxygen are available because of equipment malfunction, viable fish populations were evidence of sufficient oxygen in RMA lakes.

Phytoplankton biomass in the two RMA lakes was lower than two of the "control" lakes and similar to the third (Table 3.3). In Berkeley and Rocky Mounta in Lakes, the high phytoplankton biomass was attributable to extensive blue-green algal blooms, signifying an undesirable impact on these lakes from excessive nutrients. All values were considerably less than those listed by Pennak (1949) for several reservoirs in this area; however, in Pennak's method total organic matter is determined, while we sampled only that retained by a \#20 mesh plankton net $(50 \mu)$.

Chlorophyll a standing crop was highest in Berkeley and Rocky Mountain Lakes because of the extensive blue-green algal blooms, but was also higher in Crown Hill than in the two RMA lakes. Though chlorophyll a values in Mary and Ladora were low, they likely indicate normal levels for temperate lakes in this region.

Phytoplankton diversity was extremely low in all five lakes (Table 3.3). A single species of blue-green algae was found in two "control" lakes. Despite the fact that Berkeley and Rocky Mountain Lakes are within a few hundred meters of each other and thought to be connected, the dominant blue-green genus in each was different; in Berkeley it was Aphanizomenon and 
TABLE 3.3. Results of Plankton Sampling at Denver Area and RMA Lakes

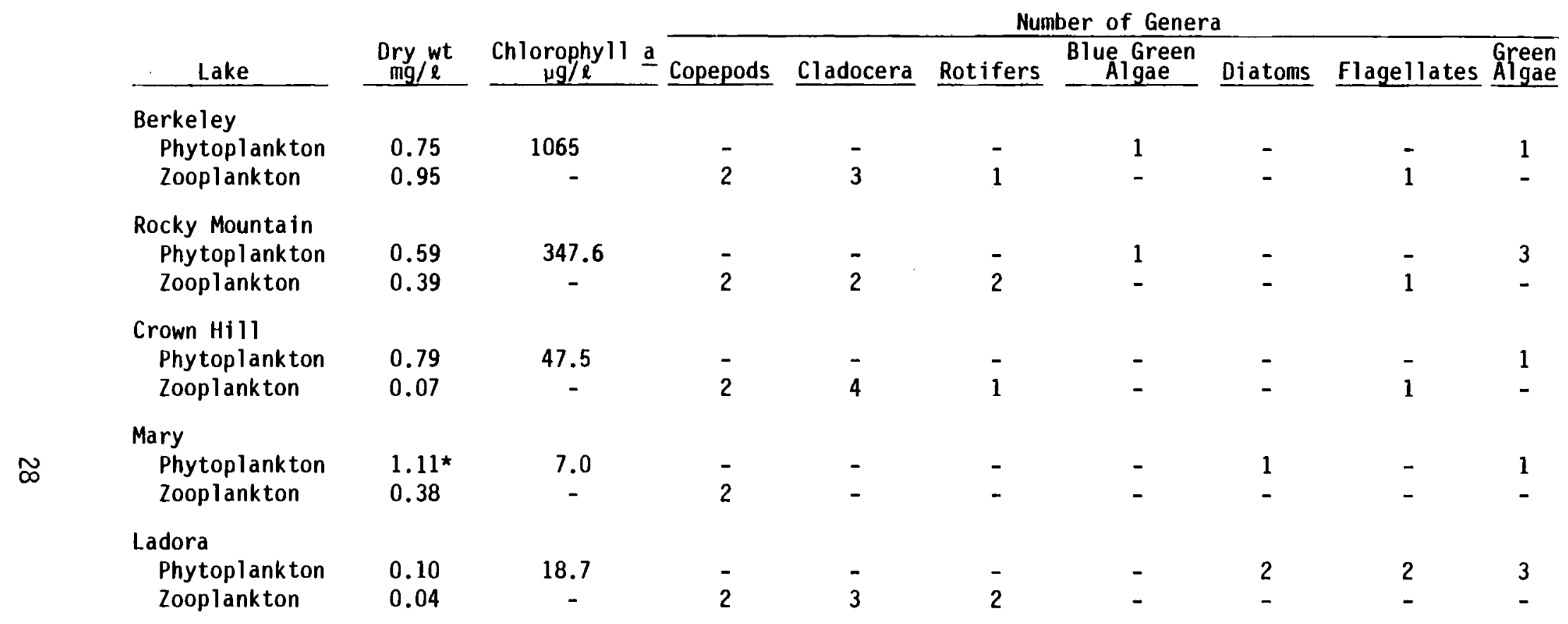

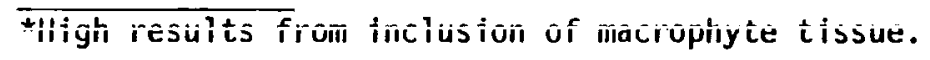


in Rocky Mountain it was Anacystis. Diatoms were found only in the RMA samples, but were sparse, particularly in Mary.

Zooplankton biomass (Table 3.3) was variable, being lowest in Ladora and highest in Berkeley. It is not known whether the low value in Ladora is attributable to adverse impacts of plant effluents. Zooplankton diversity was low for rotifers, but not unusual for the other forms. The absence of Cladocera and rotifers in Mary is unusual, and we have no explanation at this time.

Bottom fauna populations were extremely sparse in the "control" lakes, averaging less than four organisms $/ \mathrm{ft}^{2}$; all were chironomid larvae. Populations were higher and more diverse in the RMA lakes, averaging about 36 organisms $/ \mathrm{ft}^{2}$ and consisting of chironomid larvae, planaria, amphipods, and molluscs.

Our data indicate that the health of fish from the RMA lakes differs little, if any, from health of fish in "control" lakes. We calculated mean fish condition factors for common species in the five lakes (Table 3.4) and compared our results with mean values from extensive data sets in Carlander (1950). The condition factor is a derived value that indicates the relative well-being of the fish. All species from the five Colorado lakes had lower $\mathrm{K}$ (condition factor) values than mean values for these species in Carlander.

\subsection{CONCLUSIONS}

Comparison of the physical, chemical, and biological data reveals that the "control" lakes are themselves impacted to such a degree as to preclude their intended use as standards for the RMA lakes.

Our results do not, however, provide direct evidence that the populations in Lakes Mary and Ladora are not impacted by RMA plant effluents; they merely negate the "control" lake approach. Comparison of the biological data from Mary and Ladora with literature values indicates, in fact, that perturbations may be occurring. This is indicated by the low plankton biomass, the low diversity of these populations, and the low condition ( $K$ ) 
TABLE 3.4. Calculated Condition (K) Factors $^{1}$ for Denver Area and RMA Lakes

\begin{tabular}{|c|c|c|c|c|}
\hline Lake & Largemouth Bass & Bluegill & Channel Catfish & Carp \\
\hline Berkeley & 1.60 & - & 1.08 & 1.29 \\
\hline Rocky Mountain & - & 2.81 & 0.98 & 1.26 \\
\hline Crown Hill & 1.34 & 1.79 & 0.85 & 1.32 \\
\hline Mary & 1.23 & - & 1.08 & - \\
\hline Ladora & 1.41 & 2.01 & - & 2.03 \\
\hline Literature $^{2}$ & $2.31^{3}$ & $3.71^{3}$ & 2.37 & 2.2 \\
\hline
\end{tabular}

$1_{K}=\frac{w t \times 10^{5}}{L^{3}}$

2 From Carlander (1950)

3 Average of Minnesota data

factors of the fish. It is not possible to be more definitive based on this single, limited sampling.

The Battelle-Columbus bioassays of water from Mary and Ladora indicated no detectable effects (Duke et a1., 1982). We do not, however, know if the natural populations are being impacted by waste residues. A more detailed sampling effort in conjunction with a thorough literature search would be necessary to prove or disprove such an assertion.

\subsection{REFERENCES}

Carlander, K. D. 1950. Handbook of Freshwater Fishery Biology. Wm. C. Brown Co., Dubuque, Iowa.

Duke, K. M., D. J. Bean and M. P. Miller. 1982. Terrestrial and Aquatic Bioassays in Hazardous Waste Site Soil Samples. Final Report (Contract 68-02-3682) to U.S. EPA, Corval1is, Oregon.

Pennak, R. W. 1949. Annual limnological cycles in some Colorado reservoir 1akes. Ecology 19:235-267. 


\subsection{INVERTEBRATE STUDIES}

\subsection{INTRODUCTION}

Several invertebrate groups were suggested during the Denver workshop as possible indicators for determining the availability of toxic materials near waste burial sites. These included total aboveground arthropods, microarthropods, worms, grasshoppers and honeybees. Of these we selected the honeybees and microarthropods for our initial studies. Later in the season grasshoppers were included when it became apparent that they were especially abundant at the Rocky Mountain Arsenal.

This approach provided us with a wide ranging species that is known to be particularly sensitive to a variety of toxic materials (honeybees); an indicator group that develops from eggs deposited in the ground and is primarily herbivorous (grasshoppers); and a group of litter inhabitants (microarthropods).

Our intent during this first study season was to ascertain the likelihood of being able to sort out real effects, should they occur, from the natural variation associated with these study groups.

\subsection{METHODS}

Six honeybee colonies located at Richland, Washington were selected for study. Honeybee brood areas were identified according to procedures given by J. J. Bromenshenk.

The colonies were transported to the Rocky Mountain Arsenal on August 23, 1982. RMA personnel helped determine appropriate locations for the hives. Two colonies were placed on the west side of section 26 two near the soils sampling area in section 1 (near Derby Lakes), and two in the western part of section 6 (see Appendix D). Mortality data were collected on September 3, 1982. A review of the data sheets indicated that a high incidence of mortality had probably occurred (perhaps during transit). Brood areas were identified again on September 20, 1982 and mortality data collected on October 3, 1982. Pollen traps were placed on all colonies on October 3, 1982 
and collected pollen removed on 0ctober 15, 1982. The colonies were returned to Richland, WA on October 17, 1982. Adult honeytiees were collected from brood frames on October 23, 1982.

Grasshopper abundance was estimated using an ocular estimating technique (Bhatnagar and Pfadt, 1973; Report No. 225; Grasslands Biome at Colorado State University, Fort Collins). This technique consists of making visual estimates of the number of grasshoppers in plots cif $1 \mathrm{ft}^{2}$ at about $20 \mathrm{ft}$. intervals along a transect. Transects were established in the general vicinity of Basin $F$ in Section 27 (North Side), Section 26 (both north and west sides), Section 24 (southside) and along the eastern boundary of RMA in Section 32 (east side). A total of 100 samples were taken from each transect.

Microarthropods were extracted from soil samples collected at RMA on July 24, 1982. Samples were obtained from the approximate center of the smal1 mammal plots (See Appendix D). A smal1 core sampler was used, samples were stored on ice and returned to PNL for analysis. A Berlese funnel was used for the extraction with each sample placed in a separate funnel. We used a small jar filled with $70 \%$ ethanol to collect microarthropods at each funnel exit. Some samples were apparently soaked during transit because the plastic bags used to contain the soil samples were not waterproof and became wet as the ice melted. These samples are identified as "muddy" and may represent an underestimate of the actual abundance of microarthropods present. Other samples had a substantial amount of soil sift into the collecting bottles. These are identified as "not sorted." These samples could have been sorted but the procedure would be time consuming (requiring about a week's time for the seven samples) and was not deened justifiable.

\subsection{RESULTS}

The honeybee results (Table 4.1) indicate a high mortality rate for both sampling dates. Colony 31, near Upper Derby Lake, exhibited the lowest brood mortality $(7 \%)$ compared to the other colonies. This colony had very few eggs during the October 3 period so the sampling area was established using young larvae rather than eggs. The first larval instars immediately after hatching 
TABLE 4.1. Mortality of Honeybee Brood and Amount of

Pollen Collected at Rocky Mountain Arsenal

\begin{tabular}{|c|c|}
\hline $\begin{array}{l}\text { Colony } \\
\text { Number }\end{array}$ & Location \\
\hline 13 & Section 26 (Basin \\
\hline 35 & Section 26 (Basin \\
\hline 19 & Section 1 (Derby) \\
\hline 31 & Section 1 (Derby) \\
\hline $210 *$ & Section 6 \\
\hline 330 & Section 6 \\
\hline
\end{tabular}

Mean \pm standard deviation

Coefficient of variation (\%)

Number of observations

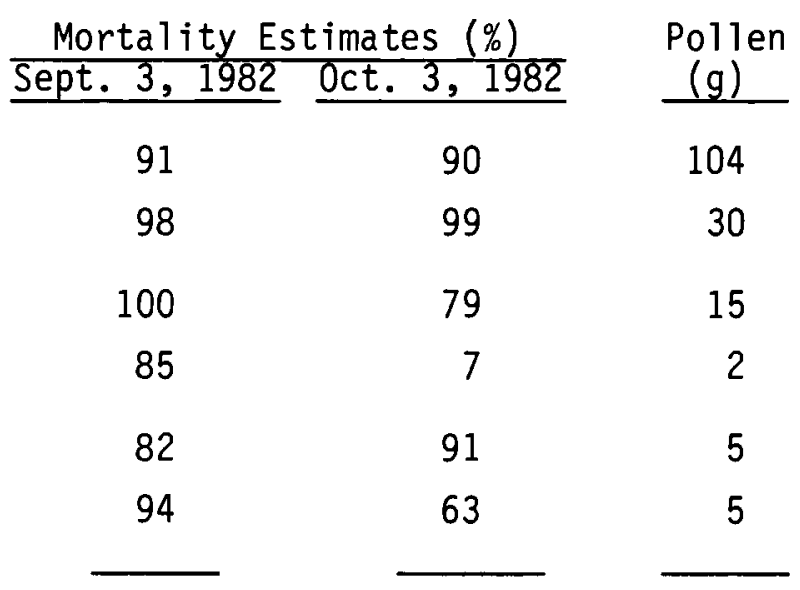

$92 \pm 7$

$83 \pm 16$

8

19

6

* Colony 210 appeared to be diseased.

are thought to be the most sensitive to toxic materials (personal communication Dr. Shimanuka; Beltsville Bee Lab; Maryland), and this may account for the relative high rate of survival of honeybee brood from colony 31 .

Results of the grasshopper study are summarized in Table 4.2 and indicate that grasshopper densities are different on different parts of the arsenal. Highest abundance occurs along the east side of the arsenal $\left(0.84 / \mathrm{ft}^{2}\right)$ and the lowest along the south part of section $24(0.30)$. Following data transformation, some mean estimates were judged to be significantly different (Table 4.2).

The abundance of major microarthropod groups contained in the samples are listed in Table 4.3 and the major findings are summarized in Table 4.4. These samples have been retained, should detailed identifications be required at a later time. 
TABLE 4.2. Summary of Grasshopper Abundance Estimates at Rocky Mountain Arsenal $\left(\bar{X}=100 ;\right.$ plots $\left.:=1 \mathrm{~m}^{2}\right)$

\begin{tabular}{|c|c|c|c|c|c|}
\hline \multirow[b]{2}{*}{ Area } & \multicolumn{2}{|c|}{$\begin{array}{c}\text { Actual Abundance } \\
\text { per } \mathrm{ft}^{2}\end{array}$} & \multicolumn{3}{|c|}{$\begin{array}{l}\text { Transformed } \\
\text { Abundance per } \mathrm{ft}^{2}\end{array}$} \\
\hline & Mean & Standard Deviation & Meän & Standard & Deviation \\
\hline $\begin{array}{l}\text { Section } 27 \\
\text { (North side) }\end{array}$ & 0.69 & 0.84 & $0.83^{\mathrm{a}}$ & & .28 \\
\hline $\begin{array}{l}\text { Section } 26 \\
\text { (West side) }\end{array}$ & 0.35 & 0.64 & $0.87^{\mathrm{a}}$ & & .29 \\
\hline $\begin{array}{l}\text { Section } 24 \\
\text { (South side) }\end{array}$ & 0.30 & 0.70 & $0.95^{\mathrm{ab}}$ & & .32 \\
\hline $\begin{array}{l}\text { Section } 26 \\
\text { (North side) }\end{array}$ & 0.51 & 0.72 & $1.013^{b}$ & & .36 \\
\hline $\begin{array}{l}\text { Section } 32 \\
\text { (East side) }\end{array}$ & 0.84 & 0.97 & $1 . c 9^{b}$ & & .40 \\
\hline
\end{tabular}

The microarthropod literature was examined and indicates that the RMA microarthropod populations apparently were not very different from those from other regions.

\subsection{SUMMARY}

A summary of the invertebrate studies (Table 4.5) shows that honeybees provided a high probability for detecting meaningful differences. These organisms appear useful as biomonitors in terms of mortality effects and results can be related to the laboratory bioassay assessments. The grasshopper studies indicated good possibilities for statistical detection of differences; however, interpretation of the results would be confounded 
TABLE 4.3. Estimates of Microarthropod Numbers at Rocky Mountain Arsenal

\begin{tabular}{|c|c|c|c|c|c|}
\hline Section & Plot & Sample & Mites & other ${ }^{1}$ & Total \\
\hline \multirow[t]{3}{*}{27} & 1 & 1 & 8 & 35 & 43 \\
\hline & & 2 & 22 & 22 & 44 \\
\hline & & 3 & 21 & 1 & 22 \\
\hline \multirow[t]{3}{*}{27} & 2 & $1^{2}$ & - & - & - \\
\hline & & $2^{2}$ & - & - & - \\
\hline & & $3^{2}$ & - & - & - \\
\hline \multirow[t]{3}{*}{32} & 1 & 1 & 4 & 0 & 4 \\
\hline & & 2 & 11 & 0 & 11 \\
\hline & & $3^{2}$ & - & - & - \\
\hline \multirow[t]{3}{*}{32} & 2 & 1 & 22 & 0 & 22 \\
\hline & & 2 & 48 & 0 & 48 \\
\hline & & 3 & 3 & 7 & 10 \\
\hline \multirow[t]{3}{*}{8} & 1 & $1^{3}$ & 0 & 1 & 1 \\
\hline & & $2^{3}$ & 2 & 1 & 3 \\
\hline & & $3^{3}$ & 2 & 3 & 5 \\
\hline \multirow[t]{3}{*}{8} & 2 & 1 & 2 & 8 & 10 \\
\hline & & $2^{2}$ & - & - & - \\
\hline & & $3^{2}$ & - & - & - \\
\hline \multirow[t]{3}{*}{9} & 1 & $1^{3}$ & 7 & 56 & 63 \\
\hline & & 2 & 9 & 1 & 10 \\
\hline & & $3^{2}$ & - & - & - \\
\hline \multirow[t]{3}{*}{9} & 2 & 1 & 10 & 7 & 17 \\
\hline & & $2^{2}$ & - & - & - \\
\hline & & $3^{3}$ & 12 & 1 & 13 \\
\hline \multicolumn{6}{|c|}{$\begin{array}{l}1 \text { Collembola, psocoptera, homoptera (pseudococcidae), thrips, hemiptera } \\
\text { (nymphs) coleoptera }\end{array}$} \\
\hline \multicolumn{6}{|c|}{2 Unsorted samples } \\
\hline \multicolumn{6}{|c|}{3 "Muddy" samples } \\
\hline
\end{tabular}


TABLE 4.4. Summary of Microarthropod Abundance Collected at Rocky Mountain Arsenal

\begin{tabular}{|c|c|c|c|c|c|c|c|c|c|}
\hline \multirow[b]{2}{*}{ Location } & \multicolumn{3}{|c|}{ Mites } & \multicolumn{3}{|c|}{ Other } & \multicolumn{3}{|c|}{ Total } \\
\hline & Mean & $\begin{array}{l}\text { Standard } \\
\text { Deviation }\end{array}$ & $\begin{array}{c}\text { Coefficient } \\
\text { of } \\
\text { Variation } \\
\end{array}$ & Mean & $\begin{array}{l}\text { Standard } \\
\text { Deviation }\end{array}$ & $\begin{array}{c}\text { Coefficient } \\
\text { of } \\
\text { Variation } \\
\end{array}$ & Mean & $\begin{array}{l}\text { Standard } \\
\text { Deviation }\end{array}$ & $\begin{array}{c}\begin{array}{c}\text { Coefficient } \\
\text { of }\end{array} \\
\text { Variation }\end{array}$ \\
\hline Section 27 & 17 & 8 & .46 & 19 & 17 & .89 & 36 & 12 & .24 \\
\hline Section 32 & 18 & 19 & 1.06 & 1 & 3 & 2.24 & 19 & 18 & .92 \\
\hline Total & 15 & 13 & .92 & 7 & 11 & 1.53 & 22 & 16 & .72 \\
\hline
\end{tabular}


TABLE 4.5. Comparison of Honeybees, Grasshoppers and Microarthropods as Useful Field Biomonitors $(+=$ Useful Characteristics)

\begin{tabular}{|c|c|c|c|c|}
\hline \multirow[b]{2}{*}{ Invertebrates } & \multicolumn{4}{|c|}{ Factors to Consider } \\
\hline & Statistics & Biomonitoring & Bioassay & Other \\
\hline Honeybees & + & + & + & + Chemical backup \\
\hline Grasshoppers & + & - & $?$ & $\begin{array}{l}\text { - Annual Cycles } \\
\text { - Biotic Interactions }\end{array}$ \\
\hline Microarthropods & - & - & - & - Biotic Interactions \\
\hline
\end{tabular}

because of the strong association between vegetative composition and structure with grasshopper abundance and the tendency for grasshopper abundance to vary dramatically from year to year. In addition, it is not clear how changes in abundance might be related to the bioassay determinations. The microarthropods do not appear to offer much hope in terms of statistical comparisons without implementing a substantial sampling effort. In addition, their role as a possible biomonitor is unclear since biotic interactions and expected annual fluctuations in population size are not well documented. It is also uncertain how changes in microarthropod abundance might be related to the bioassay determinations. 


\subsection{VEGETATION STUDIES}

\subsection{INTRODUCTION}

One of the objectives of the EPA Bio-Assessment Program is to determine if field studies can be used to detect or monitor known chemical contamination. Gradient analysis is one method frequently used to detect changes in vegetation and relate these observations to changes in the environment. Because changes in vegetation resulting from chemical toxicity are often restricted to small areas and may be compounded by other environmental factors such as soil type or topography, areas chosen for sampling should be suspected of having a chemical contamination gradient. We chose these areas at RMA based on discussions with people familiar with the present and historical uses of the arsenal (Dave Thorn, Brian Anderson, John Wardell), as well as a search of literature, maps and aerial photographs documenting land uses.

We decided to concentrate the sampling effort on three sites (Appendix D). Basin $C$ in section 26 was a dried waste pond, which caught overflow from Basin $A$ and water from a sewer leaking toxic water. It held water for a long period of time and was an area very likely to have detectable contamination. Basin E (Section 26) also displayed the possibility of toxic contamination. It received overflow water from Basins $C$ and $D$ and held water intermittently for several years. Because Section 27 contained several natural closed basins and had no known chemical contamination, we considered it a good area for comparisons.

\subsection{METHODS}

At each of the three sites, we sampled from a hilltop down into a basin. One long, continuous transect was run per site and marked with stakes at $50 \mathrm{~m}$ increments. Length of the transect and the number of locations sampled depended upon the size of the basin and the number of different vegetation types encountered.

Vegetative communities in the basins tended to be quite distinct. Generally, when possible, replicate plots were chosen within each community and transition zones. At each sample location along the transect, a 


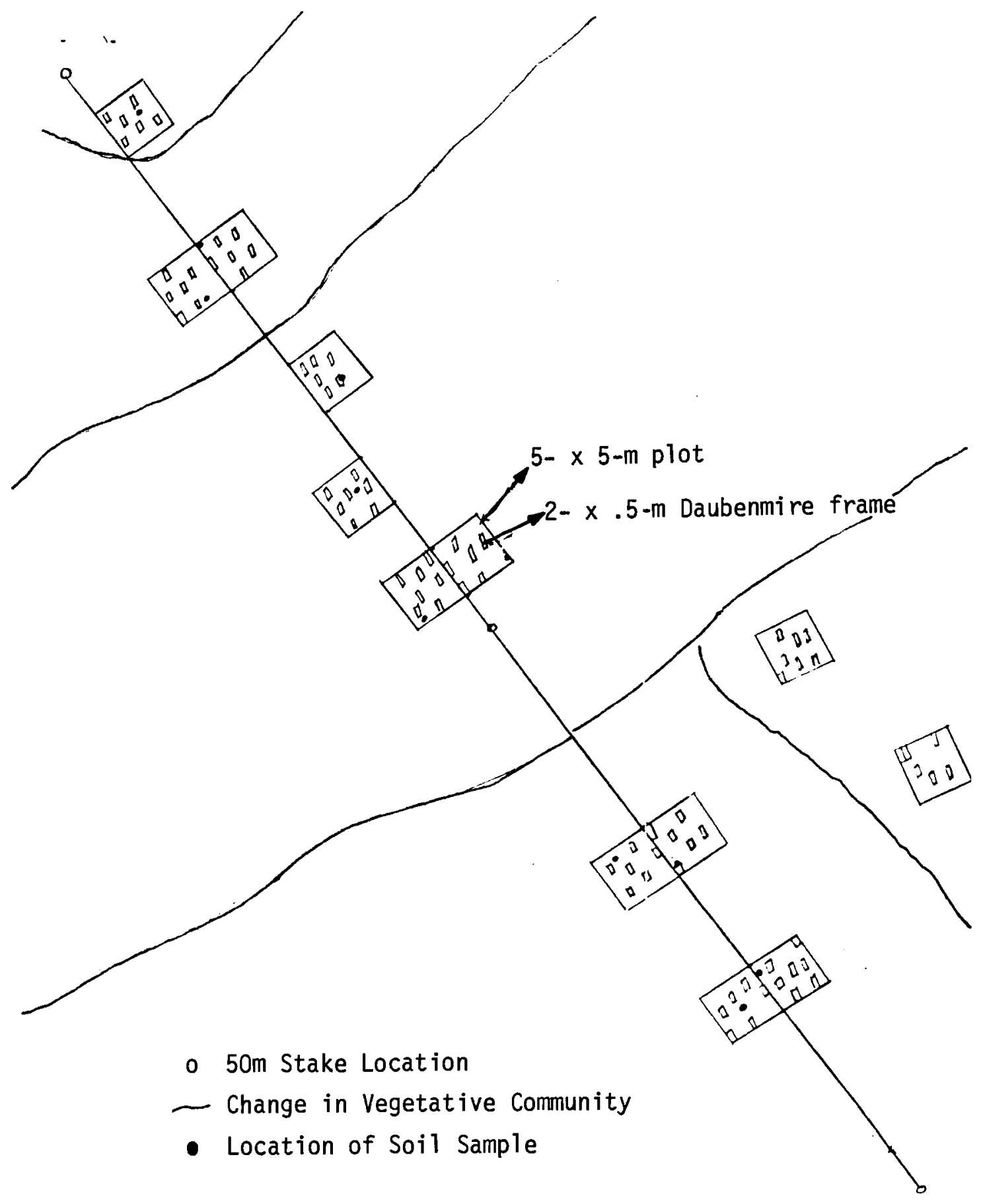

FIGURE 5.1. Hypothetical Plant Transect Showing Field Sampling Design for Vegetation and Soil (see also Figure 2.7) 
$5 \mathrm{~m} \times 5 \mathrm{~m} \mathrm{plot}$ was established. We recorded the plot's distance from the last $50 \mathrm{~m}$ stake, side of placement along the transect and slope and aspect. To avoid missing a vegetative community not crossed by the transect, we placed the $25 \mathrm{~m}^{2}$ plot out from the transect and recorded distance and direction in some cases. Six Daubenmire (1968) plot frames $(20 \times 50 \mathrm{~cm})$ were randomly placed within each $25 \mathrm{~m}^{2}$ plot and cover class values were recorded by species (Daubenmire 1968). In addition, a soil sample was taken from each of the $25 \mathrm{~m}^{2}$ plots (the location of the sample within each plot was randomly chosen). A bucket auger was used to collect the first $20 \mathrm{~cm}$ of soil. The soil samples from Basin $C$ were used for laboratory plant bioassay (see Section 8.3) to support any hypothesis that a field gradient might be the result of a chemical toxicant. In Basin C, 34 plots were sampled; in Basin $E, 58$; and in Section 27, 36 plots. An example field configuration is given in Figure 5.1 .

Results were evaluated using a computer algorithm, called "TWINSPAN," which is a variant of principal component analys is techniques that incorporates a reciprocal average weighting scheme (Hill 1979). The procedure uses actual plant cover values to divide all plots into two groups. Subsequently, an indicator species analysis is done on each group. The procedure is repeated on each group until the desired resolution is reached. In addition, mean cover by species for each transect was calculated.

\subsection{RESULTS}

The evaluation of relative vegetative cover (Table 5.1) indicated that Basin C differed from Basin $E$ and the control transect (Section 27). The latter two areas showed apparent similarities. However, indicator species analyses (Figures 5.2 and 5.3; Table 5.2) showed that: the hilltop areas of Basins $C$ and $E$ and Section 27 were all very similar; the actual basin areas were different compared to their respective hilltop areas; and Basin $C$ (basin part only) contained a paucity of vegetation (mostly annual forbs and bare ground). If the null hypothesis prior to running the clustering algorithm was not qualitatively different among basins and if that hypothesis can be rejected based on the subsequent analyses, then we tentatively conclude that 
TABLE 5.1. Results of Cover Analys is for Three ${ }_{1}$ Plant

Transects at Rocky Mountain Arsena 1

\begin{tabular}{|c|c|c|c|c|c|}
\hline Location & $\begin{array}{c}\text { Number of } \\
\text { Species } \\
\end{array}$ & $\begin{array}{l}\text { Total } \\
\text { Cover }(\%) \\
\end{array}$ & $\begin{array}{c}\text { Perennial Grass } \\
\text { Cover }(\%) \\
\end{array}$ & $\begin{array}{c}\text { Annual Grass } \\
\text { Cover }(\%) \\
\end{array}$ & $\begin{array}{l}\text { Forb } \\
\text { Cover }(\%) \\
\end{array}$ \\
\hline Basin C & 12 & 40 & 8 & 3 & 29 \\
\hline Basin $E$ & 29 & 97 & 42 & 14 & 41 \\
\hline Section 27 & 25 & 109 & 44 & 10 & 55 \\
\hline
\end{tabular}

the vegetation in Basin $C$ has been subject to some kind of impact, Basin $E$ may have been changed in some way and Section 27 represents an adequate RMA control site.

Results of seed germination tests (Neubauer) conducted on soils from Basin $C$ show little evidence of chemical contamination (based on this test), but since these samples were taken to only $20 \mathrm{~cm}$, an additional sample will be evaluated by depth during FY 1983 (see Figure 2.7 and Section 2.3.2). Based either on relative cover and species composition analyses evidence for some kind of impact is strong. The cause is unclear.

\subsection{SUMMARY}

The results of the FY 1982 field vegetation studies indicate that plant communities at RMA do change along a suspected chemical gradient. Gross changes were reflected in measurements of relative plant cover, but analyses of species composition and vegetative structure were required to determine areas of potential contamination.

\subsection{REFERENCES}

Hi11, M. 0. 1979. TWINSPAN, a Fortran Program for Arranging Multivariate Data in an Ordered Two-Way Table by Classificaticin of the Individuals and Attributes. Cornell University, I thaca, New York.

Daubenmire, R. 1958. Plant Communities, a Text Bcok of Plant Synecology. Harper \& Row, New York. 300pp. 


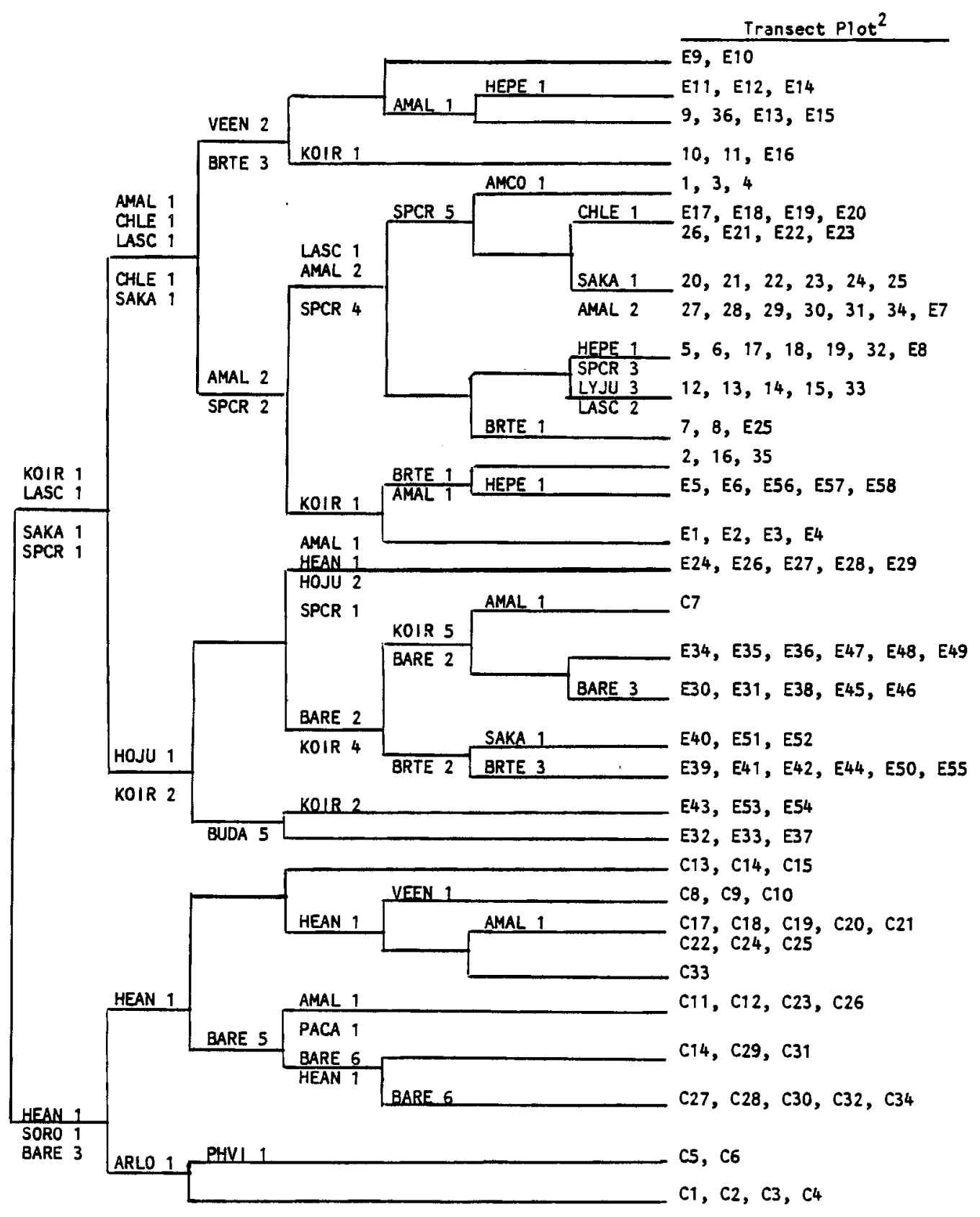

\footnotetext{
Soe Table 5.2 for an explanation of abbreviations used. Numbers following plant names are based on Daubenmire (1968) canopy class.

${ }^{2}$ plots E1-E58 from E-Basin, C1-C34 from C-Basin, 1-36 from Section 27.
}

FIGURE 5.2. Detailed Results of a "TWINSPAN" Analysis of Plant Species Composition for Three Plant Transects at Rocky Mountain Arsenal 
TABLE 5.2. Species List for Gradient Analysis Vegetation Sampling at Rocky Mountain Arsenal

\begin{tabular}{ll} 
Code & \multicolumn{1}{c}{ Scientific Name } \\
\hline SPCR & Sporobolus cryptandrus \\
ARLO & Aristida longiseta \\
STCO & Stipa comata \\
AGSM & Agropyron smithii \\
HOJU & Hordium jubatum \\
SIHY & Sitanion hystrix \\
BUDA & Buchloe dactyloides \\
PACA & Panicium capillare \\
BRTE & Bromus tectorum \\
ERCI & Eragrostis cilianensis \\
JUAR & Juncus arcticus \\
DESO & Descurania sophia \\
SOTR & Solanum triflomum \\
LASC & Lactuca scariola \\
COAR & Convolvulus arvensis \\
CHLC & Chenopodium leptophylum \\
TROC & Tradescantia occidentalis \\
KOIR & Kochia iranica \\
SPCO & Sphaeralcea coccinea \\
PSTE & Psoralea tenuiflora \\
AMAL & Amaranthus albus \\
AMRE & Amaranthus retroflexus \\
AMCO & Ambrosia coronopifolia \\
LYJU & Lygodesmia juncea \\
PHVI & Physalis virginiana \\
HEPE & Helianthus petiolaris \\
HEAN & Helianthus annuus \\
SIAL & Sisymbium altissimm \\
ARPO & Argemone polyanthemos \\
OESP & Oenothera sp. \\
SCSP & Scrophularia sp. \\
CRTE & Croton texensis \\
ERCC & Erodium cicutarium \\
VEEN & Verbesina encelioides \\
VETH & Verbascum thapsis \\
CIAR & Cirsium arvense \\
GRSQ & Grindelia squarrosa \\
SOQR & Solidago graminfolia \\
SORO & Solanum rostratum \\
SAKA & Salsola kali \\
CANU & Cardus nutans \\
&
\end{tabular}

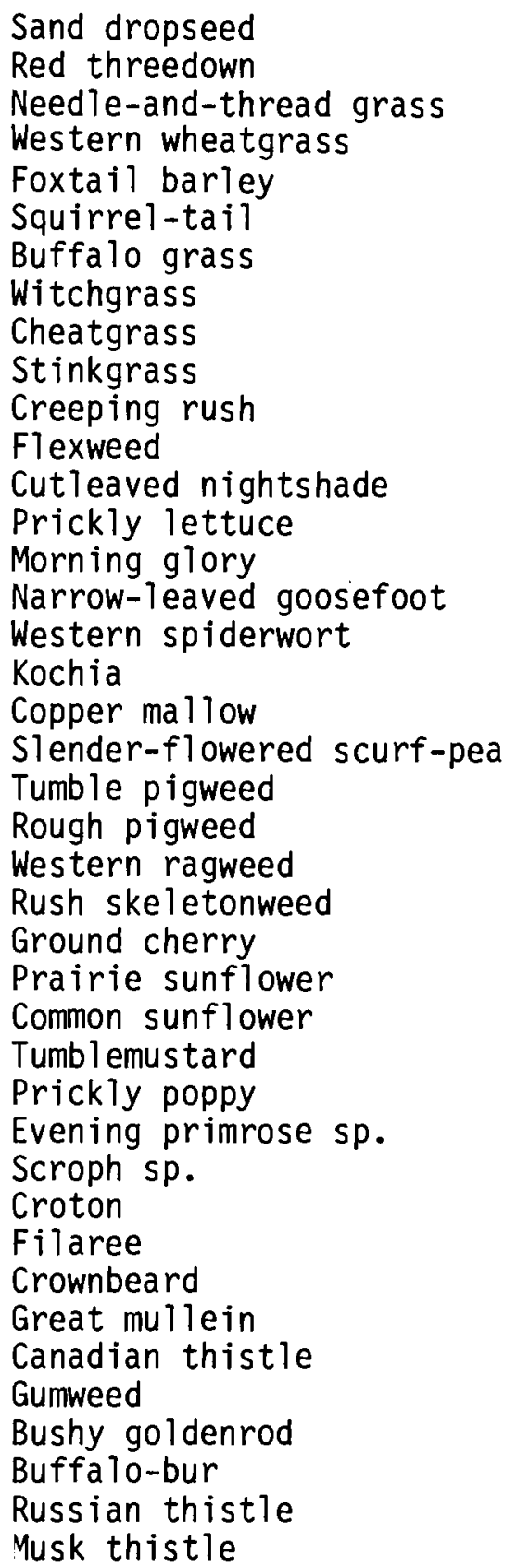


SECTION 27 AND BASIN E HILLTOP

$\triangle$ ANNUAL FORBS

$\triangle$ PERENNIAL GRASSES

BASIN E AND SECTION 27

$\triangle$ SPECIES DIVERSITY

BASIN E - BASIN

SPECIES DIVERSITY

BOTTOM

BASIN C

$\triangle$ BARE GROUND

$\checkmark$ SPECIES DIVERS ITY

$\rightarrow$ ANNUAL FORBS

H ILLTOP

BAREGROUND

ANNUAL FORBS

$\mathrm{HIGH} \triangle$

LOW $\square$

PERENNIAL GRASSES

FIGURE 5.3. Summarized Results of "TWINSPAN" Analysis of Plant Species Composition for Three Transects 


\subsection{SMALL MAMMAL STUDIES}

\subsection{INTRODUCTION}

One goal of EPA's bioassessment program is to use bioassays to assess hazardous waste sites. A second objective is to investigate the suitability and cost of in situ methods. We sought to demonstrate the accuracy of bioassays, by having in situ and soil bioassay results track one another somehow. If small mammal abundance could be used either directly or to mimic bioassays, estimates of field variability would be needed for definitive designs. For these reasons, we conducted a preliminary sampling program at the Rocky Mountain Arsenal (RMA) during spring 1982. Our goals for the preliminary study included:

- estimating the variance components associated with designing field studies.

- evaluating the usefulness of vegetation sampling programs in establishing replicates or paired sites in any future small mammal studies at RMA.

We based the protocol for the preliminary sampling program on data that would be required for several alternative experimental approaches. The approaches, which might be used to assess chemical waste effects on small mammal populations in the future, included:

- establishing a series of control-treatment pairs at a number of 10cations about RMA

- establishing a series of study plots along a suspected chemical gradient

- using independent sites at a number of control and contaminated areas.

A contrasting feature of these options is the proximity of the replicate sites. Options 1 and 2 require closely located sites; option 3 requires that sites be widely dispersed. As a result, an important aspect of the field data collection during FY82 was determining the relationship between the magnitude of the plot-to-plot variance and the spatial dispersion of replicate sites. The choice of experimental options for future research at RMA 
will depend on the site surveillance, but also or the magnitude of plot-to-plot variances and correlation in abundarce between replicate small mammal populations observed during this study.

\subsection{METHODS}

\subsubsection{Small Mammal Studies}

We established eight 1-ha study plots in sand dropseed (Sporobolus cryptandrus) habitats in order to estimate small mammal abundance (Appendix D). Within each of four areas, two replicate 1-ha plots were established for a total of eight plots. The four major sand dropseed areas were set between 2.8 - $8.0 \mathrm{~km}$ apart, while plots-within-areas (see Appendix $D$ ) were set about $0.2-1.0 \mathrm{~km}$ apart. The resulting field survey consisted of a nested design, where plots within areas (sections 8,9,27 and 32) were nested (Cochran 1977: 270-291).

At each plot, we set Sherman live-traps $11-\mathrm{m}$ apart in a $9 \times 9$ rectangular grid system (a total of 81 traps/plot) and trapped simultaneously at al1 eight plots. Trapping was conducted for five consecutive days (17-21 June 82); two days of live trapping for marking tie animals was followed by three days of removal trapping. Small mammals captured during the marking period were toe-clipped and released at respective points of capture. Species, sex and weight data were recorded for all animals captured.

Estimates of small mammal abundance were calculated by means of markrecapture (Seber 1973: 48-69), removal sampling methods (Zippin 1956, 1958) and the mark-recapture method (Skalski and Robson 1982). We tested the validity of the absolute abundance procedures with statistical tests of goodness-of-fit and tests of homogenejty (Skalski and Robson 1979, 1982). Clustering algorithms using K-means and average linkage (Hartigan 1975) were used to evaluate the success of the natural pairing of the plots-within-areas based on observed smal1 mammal communities using computer algorithms (BMDP 1979). Multivariate regression analysis (Morrison 1976: 108-116) was used to regress small mammal communities upon vegetation variables obtained at each site (BMDP 1979). 


\subsubsection{Concurrent Vegetation Studies}

The plant communities were sampled in mid-July at all eight small mammal plots and allowed us to estimate percent cover of dominant plant species and to identify habitat types. Using the existing grid system at each plot, a two-stage sampling design (Cochran 1977: 270-285) was implemented, based on a sampling of these $121-\mathrm{m}^{2}$ subplots contained in each plot. Since 81 subplots were defined by the grid system in each plot and 40 of these were sampled, the sampling intensity was 40/81. Each subplot was measured using two randomly placed $0.1-\mathrm{m}^{2}$ sampling frames (Daubenmire 1968). Thus, the subsampling fraction of the entire plot area was $0.2 / 121$. Hence, a total of 80 frames were sampled at each plot. Percent cover was recorded according to the six Daubenmire classes $(0-5,5-25,25-50,50-75,75-95,95-100 \%)$ for the commonly occurring species and fractions of the area were categorized as bare, litter or vegetated.

The categorical observations on percent cover by species were converted to the mid-points of the Daubenmire classes and statistically analyzed to estimate percent cover and the sampling error for each plot. The clustering algorithms used in statistical evaluations of the small mammal data were also used to assess similarity of plots based on plant cover data.

\subsection{RESULTS}

\subsubsection{Small Mammal Abundance Estimates and Associated Variance Components}

A total of 266 animals were captured during five days of trapping on the eight study plots. Deer mice (Peromyscus maniculatus) accounted for $31.6 \%$ of the captures, followed by harvest mice (Reithrodontomys spp.) with $21.1 \%$, and pocket mice (Perognathus flavus) with $12.4 \%$ of the catch. Six other species constituted the remainder of the captures (Table 6.1).

The presence of numerous species and relatively few captures per species complicated the estimation of animal abundance. Too few captures were available to estimate abundance of $P$. hispidus or Mus musculus, since only five and one animals were captured, respectively. Data from these species were excluded in subsequent analyses. For the remaining species, tests of 
TABLE 6.1. Number and Percent of Small Mammals Captured Over Five Days by Species and by Plot at Rocky Mountain Arsenal During June 1982

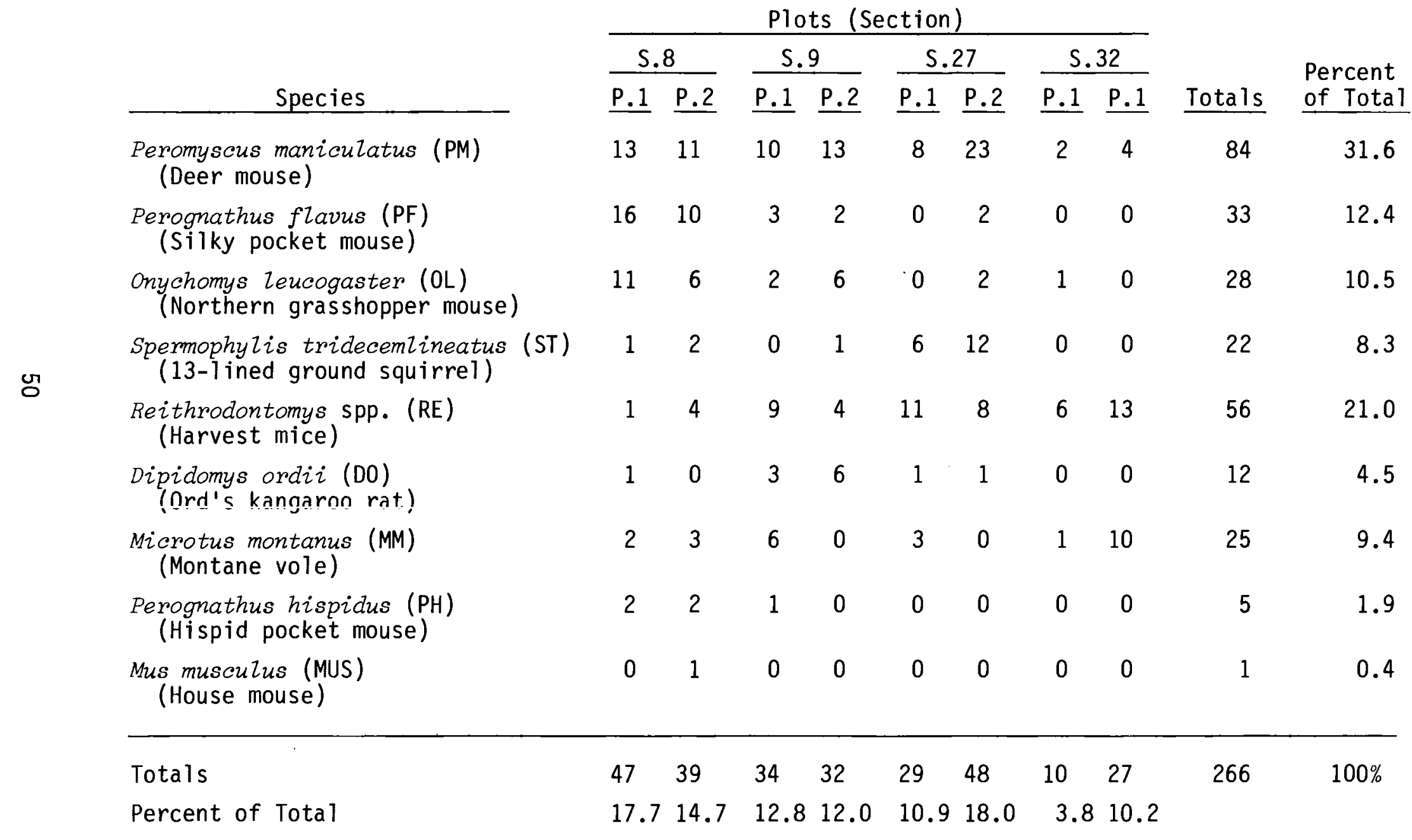


TABLE 6.2. Chi-Square Values $\left(x_{2}^{2}\right)$ and Associated Significance Levels for Pair-Wise Tests of Homogeneous Capture Probabilities (Pooled Across All Plots) Using Mark-Recapture Data

\begin{tabular}{|c|c|c|c|c|c|c|}
\hline & $\mathrm{PM}^{1}$ & $\mathrm{PF}$ & $\mathrm{OL}$ & ST & RE & MM \\
\hline PM & -- & $\begin{aligned} x_{2}^{2} & =2.39 \\
\alpha & =0.30\end{aligned}$ & $\begin{array}{l}4.38 \\
0.09\end{array}$ & $\begin{array}{l}2.88 \\
0.24\end{array}$ & $\begin{array}{l}1.93 \\
0.38\end{array}$ & $\begin{array}{l}0.46 \\
0.80\end{array}$ \\
\hline PF & & -- & $\begin{array}{l}0.52 \\
0.77\end{array}$ & $\begin{array}{l}6.54 \\
0.04\end{array}$ & $\begin{array}{l}3.66 \\
0.16\end{array}$ & $\begin{array}{l}2.98 \\
0.23\end{array}$ \\
\hline OL & & & $\cdots$ & $\begin{array}{l}9.48 \\
0.01\end{array}$ & $\begin{array}{l}5.45 \\
0.06\end{array}$ & $\begin{array}{l}5.31 \\
0.07\end{array}$ \\
\hline ST & & & & -- & $\begin{array}{l}4.36 \\
0.11\end{array}$ & $\begin{array}{l}0.85 \\
0.65\end{array}$ \\
\hline RE & & & & & -- & $\begin{array}{l}1.86 \\
0.40\end{array}$ \\
\hline MM & & & & & & - \\
\hline
\end{tabular}

*Statistically significant at $\alpha=0.10$.

${ }^{1}$ For species abbreviations, see Table 6.1 .

homogeneous capture probabilities were used to pool data across replicate plots and across species. In addition, tests of assumptions made in markrecapture and removal sampling were used to determine valid estimation procedures. Summaries of the tests of homogeneity by species over plots are presented in Tables 6.2 and 6.3. The choice of estimation procedure for the seven most abundant species is presented in Table 6.4 and is based on the information in Tables 6.2, 6.3 and 6.4 (Skalski and Robson 1979). Abundance estimates (Table 6.5) were computed by absolute abundance procedures suggested as appropriate by the tests of assumptions (Table 6.4).

Using the observed abundance data and single mark-recapture methods, estimates of the variance in abundance between areas $\left(\sigma_{A}^{2}\right)$, the variance in 
TABLE 6.3. Chi-Square Values $\left(x_{2}^{2}\right)$ and Significance Levels for the Pair-Wise Tests of Homogeneols Capture Probabilities

(Pooled Across All Plots) Using Removal Sampling Data

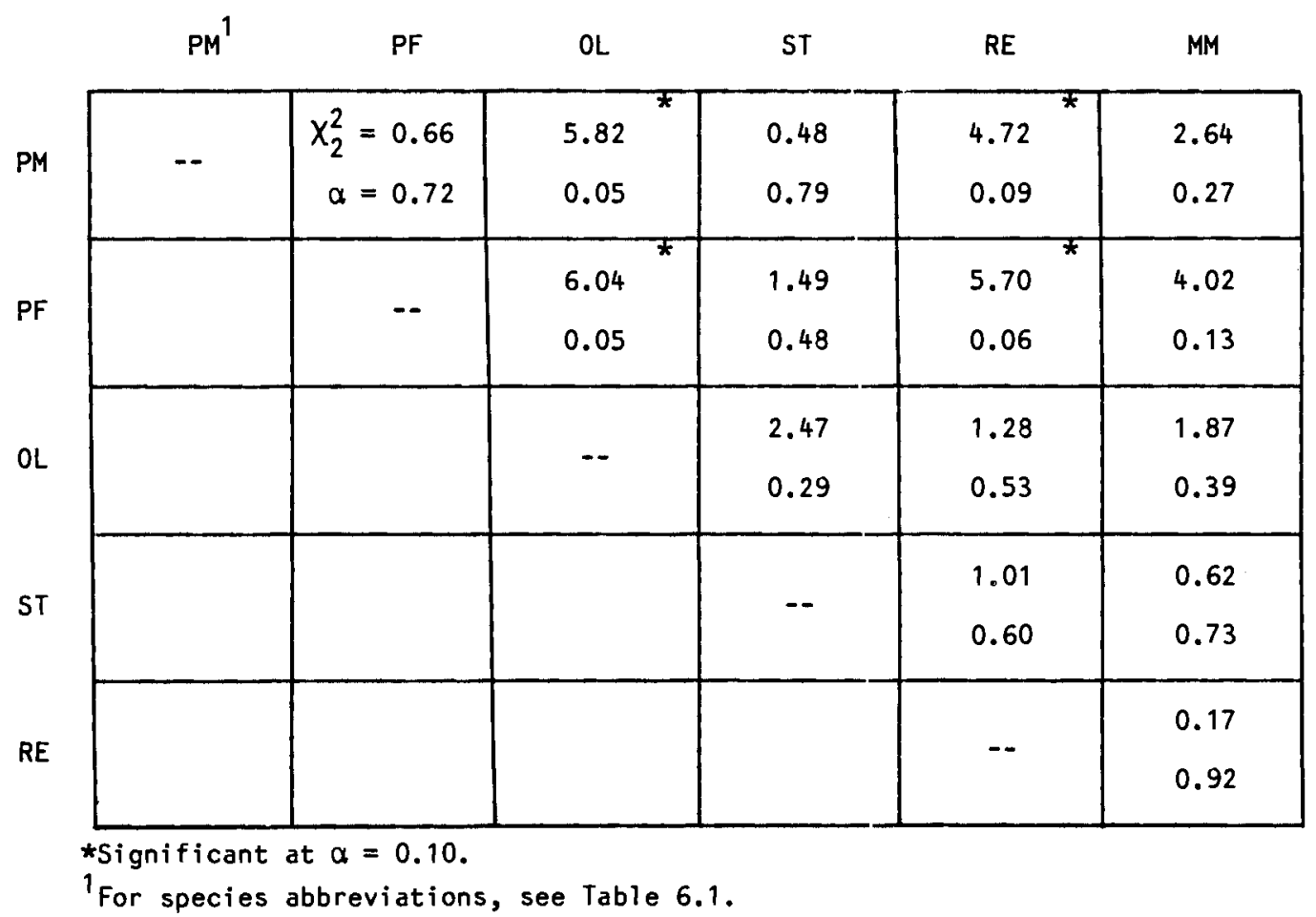

abundance between plots-within-areas $\left(\sigma_{P} / A^{2}\right)$, and the sampling error $\left(\sigma_{S E}{ }^{2}\right)$ associated with the field censuses were computed hased on the nested field survey design (Table 6.6). The variance components were estimated with 3 and 4 degrees of freedom for $\sigma_{A}^{2}$ and $\sigma_{P} / A^{2}$, respectively. Results of these analyses suggest that the variance in abundance within areas (see Appendix D) is smaller than that between areas. Since longer distances exist between areas, spatial dispersion may be the controlling influence. The only observed exception appeared with Microtus montanus (MM, Table 6.6). A possible explanation for the data on Microtus is that the micro-habitat differences which influence abundance occur across areas as short as $0.2-1.0 \mathrm{~km}$ and additional distances do not contribute to this variability. For Microtus, the best estimate of the plot-to-plot variance is $\mathrm{J}_{P / A}{ }^{2}=24.5$. 
TABLE 6.4. Results of Statistical Tests of Homogeneity and Goodness-of-Fit of Model Assumptions to Abundance Estimators and Decision on Appropriate Estimation Technique for Small Mammal Species

\begin{tabular}{|c|c|c|c|c|c|}
\hline Species ${ }^{\mathrm{a}}$ & $\begin{array}{l}\text { Homogeneity } \\
\text { Across Plots }\end{array}$ & $\begin{array}{c}\text { Homogeneity } \\
\text { Between Species }\end{array}$ & $\begin{array}{l}\text { Goodness-of-Fit } \\
\text { Removal Model }\end{array}$ & $\begin{array}{l}\text { Mark and Unmarked } \\
\text { Probabilities Equal }\end{array}$ & $\begin{array}{c}\text { Choice of Abundance } \\
\text { Estimator }\end{array}$ \\
\hline$P M$ & $\begin{aligned} \text { b) } & \star \\
\chi_{14}^{2} & =19.69 \\
\alpha & =0.14 \\
\text { c) } & \\
\chi_{14}^{2} & =22.72 \\
\alpha & =0.06\end{aligned}$ & b) $\begin{aligned} \chi_{10}^{2} & =12.52 \\
\alpha & =0.25 \\
\text { c) } & \\
\chi_{10}^{2} & =14.3218 \\
\alpha & =0.16\end{aligned}$ & $\begin{array}{l}Z=4.68 \\
\alpha=0.001 \\
\text { For marked } \\
\text { animals only }\end{array}$ & $\begin{aligned} x_{2}^{2} & =6.35 \\
\alpha & =0.04\end{aligned}$ & $\begin{array}{l}\text { Use independent } \\
\text { Lincoln estimates } \\
\text { for each population }\end{array}$ \\
\hline PF & 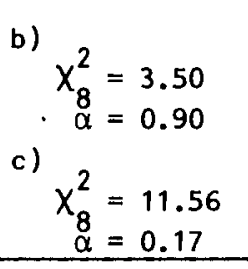 & $\begin{aligned} \text { b) } x_{10}^{2} & =16.09 \\
\alpha & =0.10 \\
\text { c) } \chi_{10}^{2} & =17.90 \\
\chi_{\alpha} & =0.06\end{aligned}$ & $\begin{array}{l}Z \text { could not be } \\
\text { computed for } \\
\text { marked or } \\
\text { unmarked }\end{array}$ & $\begin{aligned} x_{2}^{2} & =0.91 \\
\alpha & =0.63\end{aligned}$ & $\begin{array}{l}\text { Use pooled Schnabel } \\
\text { estimate using first } \\
\text { three days of } \\
\text { capture data }\end{array}$ \\
\hline $\mathrm{OL}$ & b) $\begin{aligned} \chi_{10}^{2} & =9.42 \\
\alpha & =0.49 \\
\text { c) } \chi_{\chi_{10}}^{2} & =6.75 \\
\chi_{\alpha} & =0.75\end{aligned}$ & $\begin{aligned} \text { b) } & \text { * } \\
\chi_{10}^{2} & =25.63 \\
\alpha & =0.004 \\
\text { c) } \chi_{\alpha}^{2} & =17.44 \\
\chi_{10}^{2} & =0.06\end{aligned}$ & $\begin{array}{l}z=1.04 \\
\alpha=0.30\end{array}$ & $\begin{aligned} \chi_{2}^{2} & =1.90 \\
\alpha & =0.39\end{aligned}$ & $\begin{array}{l}\text { Use pooled mark- } \\
\text { removal estimator }\end{array}$ \\
\hline $\begin{array}{l}\text { ST } \\
\text { RE } \\
\text { DO } \\
\text { MM }\end{array}$ & b) $\begin{aligned} \chi_{40}^{2} & =43.47 \\
\alpha & =0.33 \\
\text { c) }{ }^{2} & \\
\chi_{38}^{2} & =31.35 \\
\alpha & =0.77\end{aligned}$ & 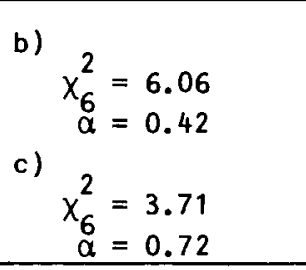 & $\begin{array}{l}z=0.38 \\
\alpha=0.70\end{array}$ & $\begin{aligned} x_{2}^{2} & =1.21 \\
\alpha & =0.55\end{aligned}$ & $\begin{array}{l}\text { Use pooled mark- } \\
\text { removal estimator }\end{array}$ \\
\hline
\end{tabular}

*Significant at $\alpha=0.10$.

a) See Table 6.1 for species abbreviations.

b) Based on mark-recapture data (days 1 and 2 ).

c) Based on removal data (days $3-5$ ). 
TABLE 6.5. Estimates of Abundance for Small Mammal Species at Eight Replicate Plots at Rocky Mountain Arsenal

\begin{tabular}{|c|c|c|c|c|c|c|c|c|}
\hline \multirow[b]{3}{*}{ Species } & \multicolumn{8}{|c|}{ Section } \\
\hline & \multicolumn{2}{|c|}{8} & \multicolumn{2}{|c|}{9} & \multicolumn{2}{|c|}{27} & \multicolumn{2}{|c|}{32} \\
\hline & $P .1$ & $P .2$ & $P .1$ & $P .2$ & $P .1$ & P.2 & $P .1$ & $P .2$ \\
\hline$P M^{1}$ & 18.25 & 10.00 & 16.50 & 16.60 & $10.6 ?$ & 29.00 & 2.00 & 4.00 \\
\hline $\mathrm{PF}$ & 13.09 & 8.18 & 2.45 & 1.64 & 0 & 1.64 & 0 & 0 \\
\hline $\mathrm{OL}$ & 12.22 & 6.66 & 2.22 & 6.66 & 0 & 2.22 & 1.11 & 0 \\
\hline ST & 1.37 & 2.73 & 0 & 1.37 & 8.201 & 16.40 & 0 & 0 \\
\hline $\mathrm{RE}$ & 1.37 & 5.47 & 12.30 & 5.47 & 15.04 & 10.94 & 8.20 & 17.77 \\
\hline DO & 1.37 & 0 & 4.10 & 8.20 & 1.37 & 1.37 & 0 & 0 \\
\hline MM & 2.73 & 4.10 & 8.20 & 0 & $4.1 \mathrm{C}$ & 0 & 1.37 & 13.67 \\
\hline $\mathrm{PH}^{2}$ & 2 & 2 & 1 & 0 & 0 & 0 & 0 & 0 \\
\hline MUS $^{2}$ & 0 & 1 & 0 & 0 & 0 & 0 & 0 & 0 \\
\hline
\end{tabular}

${ }^{1}$ For species abbreviations, see Table 6.1 .

${ }^{2}$ Unadjusted catch data.

TABLE 6.6. Estimates of mean abundance $\left(\mu_{N}\right)$, between area variance $\left(\sigma_{A}^{2}\right)$, the variance between plots-within-areas $\left(\sigma_{P} / A^{2}\right)$ and average sampling error ( $\sigma_{S E}{ }^{2}$ ) (estimated from daily capture probabilities) for small mammal species at RMA. The variance components $\sigma_{A}{ }^{2}$ and ${ }^{\top} P / A^{2}$ were estimated with 3 and 4 degrees of freedom, respiectively.

\begin{tabular}{|c|c|c|c|c|}
\hline Species & $\mu_{N}$ & $\sigma_{A}^{2}$ & $\sigma_{P / A}{ }^{2}$ & $\sigma_{S E}^{2}$ \\
\hline$P M^{1}$ & 13.38 & 27.82 & 12.26 & 38.76 \\
\hline PF & 4.12 & 31.42 & 0 & 9.28 \\
\hline $\mathrm{OL}$ & 4.04 & 14.14 & 6.32 & 1.34 \\
\hline ST & 3.87 & 30.51 & 3.23 & 6.20 \\
\hline RE & 11.25 & 13.56 & 0.28 & 29.42 \\
\hline DO & 2.11 & 7.03 & 0 & 3.38 \\
\hline MM & 4.40 & 0 & 24.46 & 7.04 \\
\hline Total & 43.17 & 124.48 & 46.55 & 95.42 \\
\hline$\sigma / \mu$ & -- & 0.2584 & 0.15804 & 0.226 \\
\hline
\end{tabular}

For species abbreviations, see Table 6.1 . 
TABLE 6.7. Product Moment Correlation Coefficient Species Abundance Between Plots-Within-Areas (Estimated with 2 Degrees of Freedom)

\begin{tabular}{|c|c|c|c|}
\hline Species & Correlation Coefficient & $\begin{array}{c}\text { Total Trapped } \\
\text { Animals } \\
\end{array}$ & $\begin{array}{c}\mu_{N} \\
\text { Estimated Mean } \\
\text { Abundance per Plot } \\
\end{array}$ \\
\hline $\mathrm{PM}^{1}$ & 0.285 & 84 & 13.4 \\
\hline $\mathrm{PF}$ & 0.980 & 33 & 4.1 \\
\hline $\mathrm{OL}$ & 0.636 & 28 & 4.0 \\
\hline$S T$ & 0.997 & 22 & 3.9 \\
\hline $\mathrm{RE}$ & 0.184 & 56 & 11.3 \\
\hline DO & 0.945 & 12 & 2.1 \\
\hline MM & -0.752 & 25 & 4.4 \\
\hline
\end{tabular}

$(\alpha=0.05, \rho=0) r=0.975$ for 2 d.f.

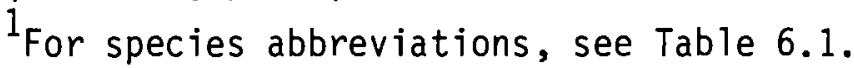

To assess the possible benefits of using paired designs in eventual field experiments at RMA, correlations in abundance among plots-within-areas were computed (Table 6.7) using the data in Table 6.5. The correlation was positive for six of the seven species, Microtus the exception again. Among the more abundant species such as Peromyscus maniculatus $(\mu=13.38$ ) and Reithrodontomys $(\mu=11.25)$, the correlation was the smallest. The highest correlations occurred among the rarer species, where presence or absence alone attributed most to the observed positive correlation.

These analyses suggest that less field replication will be necessary in experiments on chemical waste effects if control and exposure plots can be placed in close proximity to one another. On the average (Table 6.6), the variance among plots-treated-alike is $60 \%$ smaller for replicates located within $1 \mathrm{~km}$ of each other, compared with plots $2-8 \mathrm{~km}$ apart. In addition, since individual species abundance is relatively low (all plot means were 
estimated to be less than 14), total small mammil abundance may be the best variable to measure and analyze statistically ir tests of chemical waste effects. Not only will differences be easier tc detect with large animal numbers, but the value of $\sigma_{A} / \mu($ Table 6.6$)$ is smaller $(0.26)$ for total abundance than for any individual species $(0.33-1.43)$.

\subsubsection{Replicate Small Mammal Plots Needed to Detect Impacts}

Based on the variance estimates obtained during the field study and a computer algorithm devised by Skalski (1982), the number of replicate ( $n$ ) and treatment sites needed to detect impacts were calculated (Figure 6.1). When capture probabilities are assumed to be about 0.7 , neither a paired nor an unpaired design has a high probability of detecting a $25 \%$ population change (lower two curves in Figure 6.1) unless unaffordable levels of effort are deployed (at least 12 pairs or 24 plots). However, the paired design is more efficient over all levels of sampling effort. The rather inexpensive expedient of trapping for a few more days to increase capture probability to 0.6 dramatically increases the chances of detecting à $25 \%$ change; it almost assures success in detecting a $50 \%$ population change (upper two curves in Figure 6.1). Thus, it appears that a $25 \%$ change can be detected using six control and treatment sites with a power of about 0.8 . This level of field effort virtually assures that a $50 \%$ change would be detected.

\subsubsection{Floral Densities and Sampling Variances}

Based on the plant sampling conducted at RMA, estimates of cover were computed (Table 6.8) for eight grass species, all forbs collectively, and total cover, bare soil, and litter. Even though 211 plots were chosen because of the presence of Sporobolus cryptandrus, the percent cover of sand dropseed ranged from $11.1-82.7 \%$. Cheatgrass, another predominant grass species, had cover values ranging from $0-61.7 \%$, while herbaceous plant cover (forbs) ranged from 10.4 - 44.2\% cover at the eight plots. Sand dropseed, cheatgrass and forbs best characterized the plant communities on the study plots (see Section 6.3 .5 below).

Based on estimates of sampling variance, it appears that accurate surveys could be conducted to characterize plant communities at future small 


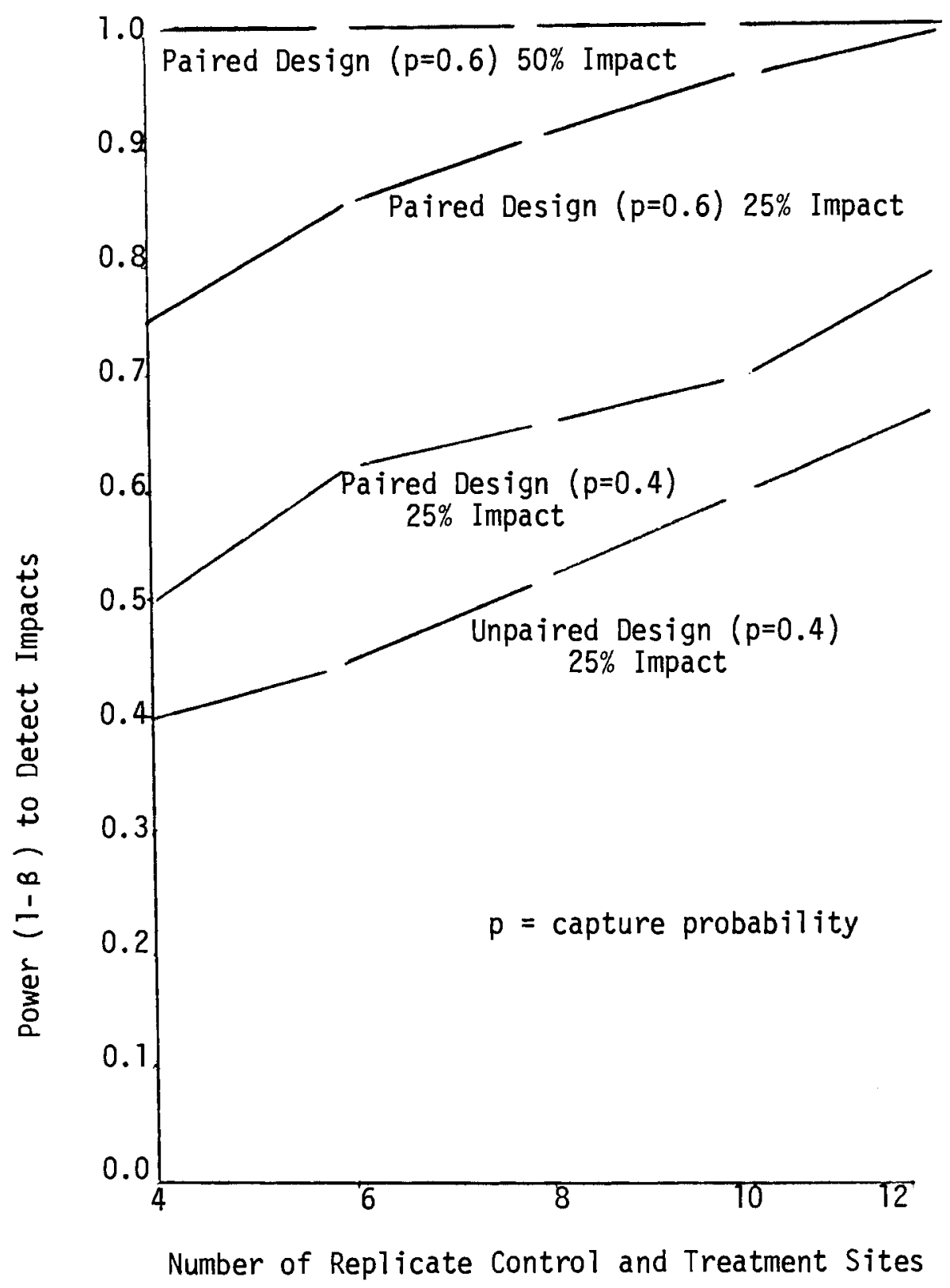

FIGURE 6.1. Comparison of Power Curves for Detecting An Impact on Sma11 Mammal Communities at Rocky Mountain Arsenal ( $\alpha=0.10$; one tailed) 
TABLE 6.8. Estimates of Plant Cover and Sampling Variances for Predominate Plant Species, Litter, Bare Soil and Total Cover at Eight Plots at RMA (Variance Estimates in Parentheses) and Number of Replicate Daubenmire Plots that Must Be Sample per 1 ha Area to Estimate Mean Density with a Precision of $\pm 5 \%$ of the Mean $95 \%$ of the Time

\begin{tabular}{|c|c|c|c|c|c|c|c|c|c|c|}
\hline & s. & & s. & & s. & & s. & & & er of \\
\hline Species & P.1 & P.2 & P.1 & P.2 & P.1 & P.2 & $P .1$ & P.2 & When Present & Daubenmire Samples \\
\hline Total Cover (TC) & $\begin{array}{l}72.5 \% \\
(8.63)\end{array}$ & $\begin{array}{l}82.6 \% \\
(5.30)\end{array}$ & $\begin{array}{l}85.6 \% \\
(3.01)\end{array}$ & $\begin{array}{l}88.8 \% \\
(5.88)\end{array}$ & $\begin{array}{l}92.6 \% \\
(0.72)\end{array}$ & $\begin{array}{l}90.8 \% \\
(2.31)\end{array}$ & $\begin{array}{l}90.6 \% \\
(0.99)\end{array}$ & $\begin{array}{l}92.9 \% \\
(1.90)\end{array}$ & $\begin{array}{l}87.0 \% \\
(3.59)\end{array}$ & $1 *$ \\
\hline Bare Sotl (BS) & $\begin{array}{l}3.8 \% \\
(0.97)\end{array}$ & $\stackrel{0.7 \%}{(0.11)}$ & $\begin{array}{l}2.5 \% \\
(0.33)\end{array}$ & $\begin{array}{l}3.3 \% \\
(1.50)\end{array}$ & $\begin{array}{l}1.5 \% \\
(0.64)\end{array}$ & $\begin{array}{c}2.4 \% \\
(0.33)\end{array}$ & $\begin{array}{l}2.2 \% \\
(0.36)\end{array}$ & $\begin{array}{l}1.0 \% \\
(0.11)\end{array}$ & $\begin{array}{l}2.2 \% \\
(0.54)\end{array}$ & 172 \\
\hline Lftter (L) & $\begin{array}{l}93.9 \% \\
(1.55)\end{array}$ & $\begin{array}{l}96.2 \% \\
(0.18)\end{array}$ & $\begin{array}{l}95.8 \% \\
(0.23)\end{array}$ & $\begin{array}{l}96.0 \% \\
(0.34)\end{array}$ & $\begin{array}{l}96.6 \% \\
(0.58)\end{array}$ & $\begin{array}{l}95.0 \% \\
(0.44)\end{array}$ & $\begin{array}{l}96.3 \% \\
(0.30)\end{array}$ & $\begin{array}{l}96.1 \% \\
(0.20)\end{array}$ & $\begin{array}{l}95.7 \% \\
(0.48)\end{array}$ & 1 * \\
\hline Forbs (F) & $\begin{array}{l}44.2 \% \\
(11.40)\end{array}$ & $\begin{array}{l}22.3 \% \\
(7.50)\end{array}$ & $\begin{array}{l}11.0 \% \\
(3.69)\end{array}$ & $\begin{array}{l}10.4 \% \\
(5.49)\end{array}$ & $\begin{array}{l}25.1 \% \\
(9.30)\end{array}$ & $\begin{array}{l}19.5 \% \\
(8.28)\end{array}$ & $\begin{array}{l}29.6 \% \\
(5.05)\end{array}$ & $\begin{array}{l}17.0 \% \\
(5.92)\end{array}$ & $\begin{array}{l}22.4 \% \\
(7.08)\end{array}$ & 21 \\
\hline $\begin{array}{l}\text { Sporobolus cryptandrus (SC) } \\
\text { (sand dropseed) }\end{array}$ & $\begin{array}{l}11.1 \% \\
(5.40)\end{array}$ & $\begin{array}{l}23.2 \% \\
(14.30)\end{array}$ & $\begin{array}{l}56.1 \% \\
(14.30)\end{array}$ & $\begin{array}{l}82.7 \% \\
(9.57)\end{array}$ & $\begin{array}{l}77.9 \% \\
(9.29)\end{array}$ & $\begin{array}{l}79.1 \% \\
(8.77)\end{array}$ & $\begin{array}{l}40.2 \% \\
(15.59)\end{array}$ & $\begin{array}{l}48.9 \% \\
(16.06)\end{array}$ & $\begin{array}{l}52.4 \% \\
(11.66)\end{array}$ & 7 \\
\hline $\begin{array}{l}\text { Bromus tectornum (BT) } \\
\text { (cheatgrass) }\end{array}$ & $\begin{array}{l}27.0 \% \\
(12.35)\end{array}$ & $\begin{array}{l}59.1 \% \\
(12.93)\end{array}$ & $\begin{array}{l}33.4 \% \\
(10.17)\end{array}$ & $N / P$ & $N / P$ & N/P & $\begin{array}{l}43.3 \% \\
(17.76)\end{array}$ & $\begin{array}{l}61.7 \% \\
(12.60)\end{array}$ & $\begin{array}{c}44.9 \% \\
(13.16)\end{array}$ & 11 \\
\hline $\begin{array}{l}\text { Aristida longiseta (AL) } \\
\quad(\text { red threeawn) }\end{array}$ & $\begin{array}{l}1.8 \% \\
(1.72)\end{array}$ & $\begin{array}{l}0.5 \% \\
(0.22)\end{array}$ & $(1.3 \%$ & $\begin{array}{l}0.4 \% \\
(0.07)\end{array}$ & $\begin{array}{l}0.9 \% \\
(0.61)\end{array}$ & $N / P$ & $\begin{array}{c}0.3 \% \\
(0.04)\end{array}$ & $\begin{array}{l}0.8 \% \\
(0.61)\end{array}$ & $\begin{array}{l}0.9 \% \\
(0.68)\end{array}$ & 1290 \\
\hline $\begin{array}{l}\text { Stipa comata (SC) } \\
\text { (needle-and-thread) }\end{array}$ & $\begin{array}{l}0.9 \% \\
(0.29)\end{array}$ & $\begin{array}{l}0.7 \% \\
(0.25)\end{array}$ & $(1.1 \%)$ & N/P & $\mathrm{N} / \mathrm{P}$ & $\begin{array}{l}4.8 \% \\
(4.70)\end{array}$ & $N / P$ & $N / P$ & $\begin{array}{l}1.9 \% \\
(1.59)\end{array}$ & 677 \\
\hline $\begin{array}{l}\text { Sitanion hystrix (SH) } \\
\text { (squirrel tail) }\end{array}$ & $N / P$ & $\begin{array}{l}0.5 \% \\
(0.22)\end{array}$ & $\mathrm{N} / \mathrm{P}$ & $N / P$ & $N / P$ & $\begin{array}{l}0.5 \% \\
(0.22)\end{array}$ & $\begin{array}{l}1.2 \% \\
(0.32)\end{array}$ & $\begin{array}{l}0.2 \% \\
(0.04)\end{array}$ & $\begin{array}{l}0.6 \% \\
(0.20)\end{array}$ & 853 \\
\hline $\begin{array}{l}\text { Punicwn capillare (PC) } \\
\text { (witchgrass) }\end{array}$ & $N / P$ & $N / P$ & $N / P$ & $\begin{array}{l}1.9 \% \\
(0.92)\end{array}$ & N/P & $\mathrm{N} / \mathrm{P}$ & $N / P$ & N/P & $\begin{array}{l}1.9 \% \\
(0.92)\end{array}$ & 392 \\
\hline $\begin{array}{l}\text { Eragrostis ciliunensis (EC) } \\
\text { (stinkgrass) }\end{array}$ & N/P & $N / P$ & $N / P$ & $\begin{array}{l}0.2 \% \\
(0.04)\end{array}$ & $N / P$ & $N / P$ & $N / P$ & $N / P$ & $\begin{array}{l}0.2 \% \\
(0.04)\end{array}$ & 1537 \\
\hline $\begin{array}{l}\text { Schedomiavous yaniculatus (SP) } \\
\text { (tumblegrass) }\end{array}$ & $N / P$ & $N / P$ & $N / P$ & $N / P$ & $N / P$ & $N / P$ & $N / P$ & $\begin{array}{c}0.5 \% \\
(0.22)\end{array}$ & $\begin{array}{l}0.5 \% \\
(0.22)\end{array}$ & 1352 \\
\hline
\end{tabular}

\#Larger sample sizes will obviously be needed to obtain valid variance estimates.
$N / P=$ Not present. 
mammal plots using a minimum of 25 Daubenmire samples/ha. The 25 samples have the potential of estimating the percent cover of forbs, cheatgrass and sand dropseed with a precision of $\pm 5 \%$ of the mean $95 \%$ of the time. Much smaller sample sizes may be used to estimate total cover and plant litter, which appear to be very homogeneous. However, because precise estimation of cover for the six less common grass species will require inordinate levels of effort, future surveys probably should not focus so intensely on these rarer species (at least in the sections studied).

\subsubsection{Evaluation of Pairing Success of Small Mammal Communities Using Clustering Algorithms}

The nested design of the field study permits an evaluation of the success of the pairing formed by the plots-within-areas. If plots can be paired simply by placing replicates in close proximity, our field experiment should demonstrate this principle. At each of the four sand dropseed areas, two replicate 1-ha plots were established. Table 6.7 indicates a positive correlation in abundance among plots-within-areas on a species by species basis. Using clustering algorithms, however, the structure of the small mammal communities can be compared using the vectors of estimated species abundance shown in Table 6.5.

Using an average linkage algorithm and mammal species PM, PF, OL, ST, $R E$, DO, MM (see Table 6.1 for definition of abbreviations), we compared plots for the presence of pairs. A "backwards step-wise" approach was used with the average linkage algorithm. After each step in the program where a pair of sites was identified to be most similar, the data from those sites were removed before the next step in the clustering procedure. Three cluster analyses were required to identify four site pairs. The average linkage algorithm formed site pairs in the following order:

Average linkage: small mammal data

1. S.8-P.1, S.8-P.2

2. S.9-P.1, S.27-P.1

3. S.32-P.1, S.32-P.2

4. S.9-P.2, S.27-P.2 
The algorithm "found" two of the four plot pairs we established.

The K-means algorithm can be used to form a specified number of clusters automatically without the need for the step-wise procedures necessary with average linkage. However, the number of elements (plots in sections) chosen in each cluster may not be the same, and cannot se controlled. The K-means algorithm formed four clusters of plots in the order:

K-means: small mammal data

$$
\begin{aligned}
& \text { 1. S.27-P.2 } \\
& \text { 2. S.27-P.1, S.32-P.1, S.32-P.2 } \\
& \text { 3. S.8-P.1, S.8-P.2 } \\
& \text { 4. S.9-P.1, S.9-P.2 }
\end{aligned}
$$

Again the algorithm found two of the four pairs we established, an illustration that different clustering techniques may result in different pairing schemes.

Results of these clustering studies suggest that placing plots in close proximity may be a necessary but not sufficient basis for identifying successful pairing schemes. Initial pairing was based solely on a visual survey of vegetative characteristics of plots; failure to reconstruct pairs using clustering algorithms may be the consequence of overlooked, but key habitat characteristics that influenced mammal populations.

\subsubsection{Evaluating Pairing Success of Plant Communities Using Clustering Algorithms}

Using the average linkage and $K$-means algorithms as outlined above, the vegetative data (Table 6.8) were used to determine the ability of clustering techniques to identify plot pairs. Regardless of whether all 12 plant variables or simply $F, S C$ and BT (see Table 6.8) were used, the average linkage algorithm formed the following pairs of plots in the order:

Average linkage: plant data
1. S.27-P.1, S.27-P.2
2. S.32-P.1, S.32-P.2
3. S.8-P.1, S.8-P.2
4. S.9-P.1, S.9-P.2 
The robustness of the clustering algorithm to the removal of all variables except F, SC and BT suggests the importance of these three measurements in defining the plant communities. The K-means algorithm failed to identify any of the pairs of plots using the vegetation data. Moreover, because the procedure was sensitive to the selection of response variables analyzed, it probably should not be used in the future.

\subsubsection{Multivariate Regression of Small Mammal Communities on Plant Community Data}

Successful pairing of plots based on small mammal abundance requires more than a consideration of plot proximity. The objective of the multivariate regression was to determine whether the structure of small mammal communities could be predicted based on observations of the plant community. An important premise of this analysis is that animal communities reflect the environment in which they live and that the structure of the plant community is an important factor that influences species selection and abundance. We regressed the seven most abundant species (PM, PF, OL, ST, RE, DO and MM; Table 6.5) against a maximum of seven ( 8 plots minus $1=$ degrees of freedom) vegetation parameters.

The multivariate regression equation which was found to describe the small mammal community best included five mammal species and three vegetation cover measurements. The regression equation had 4 degrees of freedom for error estimation. The equation was

$$
\left[\begin{array}{l}
\mathrm{PM} \\
\mathrm{PF} \\
\mathrm{OL} \\
\mathrm{RE} \\
\mathrm{DO}
\end{array}\right]=\left[\begin{array}{r}
62.29 \\
33.91 \\
36.71 \\
-28.46 \\
20.81
\end{array}\right]+\left[\begin{array}{ccc}
-0.616 & -0.406 & -0.488^{\star} \\
-0.259^{\star} & -0.356^{\star} & -0.217^{\star} \\
-0.328^{\star} & -0.352^{\star} & -0.251^{\star} \\
0.363 & 0.409^{\star} & 0.302^{\star} \\
-0.329 * & -0.138 & -0.149^{\star}
\end{array}\right]\left[\begin{array}{c}
\mathrm{F} \\
\mathrm{SC} \\
\mathrm{BT}
\end{array}\right]
$$

*indicates regression coefficients significant at $\alpha=0.10$ 
TABLE 6.9. Comparison of Small Mammal Aburidance Estimates with Values Predicted by the Multivariate Fegression Equation (Predictions in Parentheses)

\begin{tabular}{|c|c|c|c|c|c|c|c|c|}
\hline \multirow[b]{2}{*}{ Species } & \multicolumn{2}{|c|}{ Sec. 8} & \multicolumn{2}{|c|}{ Sec. 9} & \multicolumn{2}{|c|}{ Sec. 27} & \multicolumn{2}{|c|}{ Sec. 32} \\
\hline & P.1 & P.2 & P.1 & P.2 & P.1 & P. 2 & P.1 & P.2 \\
\hline $\mathrm{PM}^{1}$ & $\begin{array}{c}18.25 \\
(17.38)\end{array}$ & $\begin{array}{l}10.00 \\
(10.29)\end{array}$ & $\begin{array}{c}16.50 \\
(16.44)\end{array}$ & 16. & $\begin{array}{c}10.67 \\
(15.20)\end{array}$ & 29. & $\begin{array}{c}2.00 \\
(6.60)\end{array}$ & $\begin{array}{l}4.00 \\
(1.86)\end{array}$ \\
\hline PF & & & $\begin{array}{l}2.45 \\
(3.84)\end{array}$ & & $\begin{array}{c}3 \\
0.32)\end{array}$ & & $\begin{array}{c}0 \\
(2.54)\end{array}$ & $(-1$ \\
\hline $\mathrm{OL}$ & $\begin{array}{c}12.22 \\
(11.53)\end{array}$ & $\begin{array}{r}6.6 \\
(6.4\end{array}$ & $\begin{array}{c}2.22 \\
(4.97)\end{array}$ & $\begin{array}{r}6.6 \\
(4.1\end{array}$ & $\stackrel{10}{(1.06)}$ & $\begin{array}{c}2.22 \\
(2.47)\end{array}$ & $\begin{array}{l}1.11 \\
(1.98)\end{array}$ & $\begin{array}{c}0 \\
(-1.5\end{array}$ \\
\hline RE & $\begin{array}{c}1.37 \\
(0.28)\end{array}$ & $\begin{array}{c}5.47 \\
(6.97)\end{array}$ & $\begin{array}{l}12.30 \\
(8.56)\end{array}$ & $\begin{array}{r}5.4 \\
(9.1\end{array}$ & $\begin{array}{l}15.04 \\
(12.51)\end{array}$ & $\begin{array}{l}10.94 \\
(10.97)\end{array}$ & $\begin{array}{c}8.20 \\
(11.80)\end{array}$ & $\begin{array}{l}17.7 \\
(16.3\end{array}$ \\
\hline DO & $\begin{array}{l}1.37 \\
(0.71)\end{array}$ & $\begin{array}{c}0 \\
(1.47)\end{array}$ & $\begin{array}{c}4.10 \\
(4.47)\end{array}$ & $\begin{array}{c}8.20 \\
(5.98)\end{array}$ & $\begin{array}{l}1.37 \\
(1.80)\end{array}$ & $\begin{array}{l}1.37 \\
(3.48)\end{array}$ & $\begin{array}{c}0 \\
(-0.93)\end{array}$ & $\begin{array}{c}0 \\
-0.7\end{array}$ \\
\hline
\end{tabular}

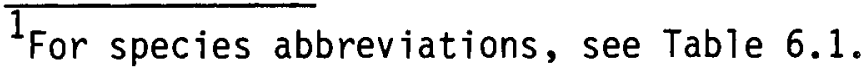

Two sma11 mammal species, ST and MM, could not be described successfully with the vegetation data. Comparisons between abundance estimates (Table 6.5) and estimates predicted by the multivariate regression equation reveal that overall estimates from the regression equation are quite good (Table 6.9).

The three vegetative cover parameters which jermitted correct clustering of the plots (using average linkage) were also the most useful for predicting smal1 mammal communities. Cover estimates of parameters F, SC and BT were the most variable of the vegetation measurements (Table 6.8); it seems logical that a parameter must have plot-to-plot variation to have predictive value. Litter (L) and total cover (TC) are relatively constant and incapable of explaining environmental heterogeneity; they should be omitted in future surveys.

While $F, S C$ and BT seem useful in pairing plcits and predicting subsequent overall mammal communities, a verification of these findings would 
require a second year's field data. One year's results do not establish a cause and effect relationship between species composition and cover and faunal abundance or patterns.

The objective of constructing the multivariate regression equation was to provide a means to predict small mammal abundance using inexpensive vegetation sampling. Predictions based on the regression equation could then be used to select homogeneous replicate plots, and an experiment in chemical waste effects could be conducted effectively and more economically. Since the regression equation was constructed using only one year's data, the model may correctly predict species composition, but should not be expected to predict accurate abundance levels in the future. The model does not take into account such driving variables as weather and parental stock. However, it is reasonable to expect if plots with homogeneous community structure can be identified, mammal abundance on such plots should also be homogeneous.

\subsection{SUMMARY}

Surveys of small mammal populations and vegetation were conducted to determine the level of field replication and sampling effort needed to detect changes that might result from effects of chemical waste. A multi-plot study was conducted to estimate needed variance components and to evaluate alternative designs. Results of the small mammal study indicate that an experimental design which incorporates six control and treatment pairs has a high probability of detecting a $25 \%$ difference when capture probabilities are about 0.6. In addition, total abundance should be measured on replicate plots located $1 \mathrm{~km}$ apart. Vegetation sampling results showed that percent cover of forbs, sand dropseed and cheatgrass sufficiently characterized plant communities at RMA plots and that animal abundance estimates were strongly related to the cover of these plant species. Thus, except for unusual circumstances (i.e., rodenticide), it appears that effects on small mammals may be projected from observed effects on plant communities. 


\subsection{REFERENCES}

BMDP. 1979. Biomedical Computer Programs P-Series. Eds. W. J. Dixon and M. B. Brown. University of California Press, Berketey, California. $880 \mathrm{pp}$.

Cochran, W. G. 1977. Sampling Techniques. 3rd Ed. John Wiley and Sons, New York. $413 \mathrm{pp}$.

Daubenmire, R. 1968. Plant Communities, a Textbook of Plant Synecology. Harper and Row, New York. 300 pp.

Hartigan, J. A. 1975. Clustering Algorithms. John Wiley and Sons, New York. $351 \mathrm{pp}$.

Morrison, D. F. 1976. Multivariate Statistical Methods. McGraw-Hill Book Co., New York. 415 pp.

Seber, G. A. F. 1973. The Estimation of Animal Abundance and Related Parameters. Charles Griffin and Co., Ltd., London, U. K. $506 \mathrm{pp}$.

Skalski, J. R., and D. S. Robson. 1979. Tests of homogeneity and goodness-of-fit to a truncated geometric model for removal sampling. In Sampling Biological Populations, eds. R. M. Cormack, G. P. Patel, and D. S. Robson, pp. 283-313. Int. Co-operative Publ. House, Fairland, Maryland.

Skalski, J. R. and D. S. Robson. 1982. A mark and removal field procedure for estimating population abundance. ‥ Wildl. Manage. 46:741-751.

Skalski, J. R. 1982. Towards the use of faunal jopulations as cost-effective biomonitors. Paper presented at Issues and Tecinnology in the Management of Impacted Western Wildlife: A Symposium. Thorne Ecological Institute. 15-17 November 1982, Steamboat Springs, Colorado. (Proceedings in press.)

Zippin, C. 1956. An evaluation of the removal method of estimating animal populations. Biometrics 12:163-189.

- 1958. The removal method of population estimation. $\underline{J}$. Wildl. Manage. $22: 32-90$. 


\subsection{MICROBIOLOGICAL BIOASSAYS}

\subsection{LABORATORY STUDY OF $\mathrm{CO}_{2}$ PRODUCTION AND COMPARISON WITH DEHYDROGENASE BIOASSAY}

\subsubsection{Introduction}

A laboratory study was conducted to determine the effect of Basin $F$ water and Basin $\mathrm{F}$ well water on the production of $\mathrm{CO}_{2}$ from alfalfa-amended (1\%) control soil (obtained from a proposed control study site at Rocky Mountain Arsenal, see Section 2.0). At the termination of the $\mathrm{CO}_{2}$ study, amended soil subsamples were taken and analyzed for biomass (dehydrogenase assay) and the chemical form of nitrogen $\left(\mathrm{NO}_{3}\right.$ and $\left.\mathrm{NH}_{4}^{+}\right)$. These studies were conducted to assess the feasibility of using $F$ Basin water to contaminate RMA soil and supply information for the design of a proposed field plot study. A secondary objective was to compare the dehydrogenase and $\mathrm{CO}_{2}$ bioassays.

\subsubsection{Methods}

Soils were collected as described in Section 2.0, dried and mixed at PNL and subsequently sieved through a $2 \mathrm{~mm}$ screen. The sieved soil (2 mm) was amended to a level of $1 \%$ alfalfa (for chemical analysis see Table 7.1) and mixed until homogeneous in a $\mathrm{V}$-blender. The mixture was then subsampled to prepare individual soil reaction vessels.

Reaction vessels contained $400 \mathrm{~g}$ of the amended soil plus sufficient test solution to bring the water content to $60 \%$ of field capacity ( $80 \mathrm{ml}$ per vesse1). Test solutions consisted of $100,10,1.0,0.1$ and $0 \%$ of either Basin $F$ well water or Basin $F$ water. After the addition of the test solutions, the reaction vessels were incorporated into an aeration apparatus that supplied moisture and $\mathrm{CO}_{2}$ free air to each vessel and trapped $\mathrm{CO}_{2}$ by

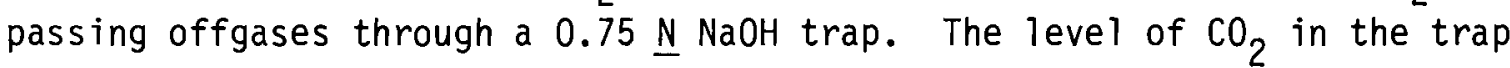
was measured periodically using an oceanographic carbon analyzer operating in the inorganic mode.

\subsubsection{Results}

The results from these studies (Table 7.2) indicate that inhibition of $\mathrm{CO}_{2}$ production was only observed with the $100 \%$ Basin $\mathrm{F}$ water test solution. 
TABLE 7.1. Elemental Analys is of Ground Alfalfa Used to Amend Soil from Rocky Mountain Arsenal

\begin{tabular}{cc} 
Element & Percent Dry Weight \\
\cline { 1 - 2 } C & 34.51 \\
H & 5.30 \\
N & 3.24 \\
O & 31.20 \\
P & 0.24 \\
S & 0.64
\end{tabular}

TABLE 7.2. Results of $\mathrm{CO}_{2}$ Bioassay (Heterotrophic Mineralization) after 30 Day Incubation

\begin{tabular}{lcc} 
& $\begin{array}{c}\text { Concentration } \\
\text { Added }(\%)\end{array}$ & $\begin{array}{c}\mathrm{CO}_{2} \text { Produced } \\
(\% \text { of Control })\end{array}$ \\
\cline { 2 - 3 } Basin F Water & 100 & 7 \\
& 10 & 93 \\
& 1 & 87 \\
Well Water & 0.1 & 107 \\
& 100 & 87 \\
& 10 & 100 \\
1 & 107 \\
& 0.1 & 93
\end{tabular}


TABLE 7.3. $\mathrm{NO}_{3}^{-}$and $\mathrm{NH}_{4}^{+}$in Soil ( $\mu \mathrm{g} / \mathrm{g}$ dry weight) after 30 Day Incubation

\begin{tabular}{|c|c|c|c|c|}
\hline \multirow{2}{*}{$\begin{array}{l}\text { Sample } \\
\text { Control }\end{array}$} & \multirow{2}{*}{$\begin{array}{c}\begin{array}{l}\text { Concentration } \\
\text { Added }(\%)\end{array} \\
0\end{array}$} & \multicolumn{2}{|c|}{$\begin{array}{c}\mathrm{NO}_{3}^{-} \\
(\mathrm{KCl} \text { Extractable) } \\
\end{array}$} & \multirow{2}{*}{$\frac{{ }_{\text {(Water Extractable) }}^{\mathrm{NH}_{4}^{+}}}{5.6 \pm 0.2}$} \\
\hline & & 590 & $\pm 70^{1}$ & \\
\hline $\mathrm{F}-100(\%)$ & 100 & 1030 & \pm 10 & $10900 \pm 300$ \\
\hline$F-10$ & 10 & 16.8 & \pm 17.3 & $3300 \pm 20$ \\
\hline$F-1$ & 1 & 1100 & \pm 32.0 & $8.4 \pm 1.7$ \\
\hline$F-0.1$ & 0.1 & 750 & \pm 30 & $4.2 \pm 0.2$ \\
\hline$W-100$ & 100 & 740 & \pm 30 & $3.2 \pm 0.2$ \\
\hline$W-10$ & 10 & 670 & \pm 40 & $3.8 \pm 0.2$ \\
\hline$W-1$ & 1 & 650 & \pm 50 & $4.4 \pm 0.3$ \\
\hline$W-0.1$ & 0.1 & 520 & \pm 70 & $3.7 \pm 0.0$ \\
\hline \multicolumn{2}{|c|}{$\begin{array}{l}\text { Control soil } \\
\text { before amendment }\end{array}$} & 72 & & 3.3 \\
\hline
\end{tabular}

Essentially no effect was observed with the lower concentrations of Basin $F$ water or Basin $\mathrm{F}$ well water over the range of test solution concentrations. Organic carbon added to the reaction vessels from the test solutions apparently was not degraded to $\mathrm{CO}_{2}$ because enhancement of $\mathrm{CO}_{2}$ production was not observed. Also, when it is assumed that $250 \%$ of the $\mathrm{C}$ added as alfalfa was converted to $\mathrm{CO}_{2}$, the $\mathrm{CO}_{2}$ produced could be accounted for. Apparently, organic carbon present in either Basin $F$ or Basin $F$ well water was not readily mineralized.

When the $\mathrm{CO}_{2}$ study was completed, subsamples of the soils were analyzed for $\mathrm{NO}_{3}$ (KCl-extractable ion chromatography) and $\mathrm{NH}_{4}^{+}$(water-extractable ion specific electrode), as well as biomass (dehydrogenase assay). The results from these studies are reported in Tables 7.3 and 7.4. Both $\mathrm{NO}_{3}{ }^{-}$and $\mathrm{NH}_{4}{ }^{+}$ 
TABLE 7.4. Soil Microbial Biomass (Dehydrogenase) after 30 Days Incubation

\begin{tabular}{|c|c|c|}
\hline Sample & $\begin{array}{l}\text { Concentration } \\
\text { Added }(\%) \\
\end{array}$ & $\begin{array}{l}\text { ug formizone/g } \\
\text { (Soil Dry Weight) }\end{array}$ \\
\hline Control & 0 & $1_{31.42 \pm 23.68}$ \\
\hline$F-100(\%)$ & 100 & $6.58 \pm 1.08$ \\
\hline$F-10$ & 10 & $50.37 \pm 11.13$ \\
\hline$F-1$ & 1 & $17.47 \pm 4.88$ \\
\hline$F-0.1$ & 0.1 & $39.47 \pm 10.13$ \\
\hline$W-100$ & 100 & $39.64 \pm 8.26$ \\
\hline$W-10$ & 10 & $48.32 \pm 9.64$ \\
\hline W-1 & 1 & $40.30 \pm 0.77$ \\
\hline$W-0.1$ & 0.1 & $44.40 \pm 11.95$ \\
\hline
\end{tabular}

showed greater sensitivity compared to $\mathrm{CO}_{2}$ production; effects were observed at lower concentrations of Basin $F$ water. Only marginal effects, however, were observed with Basin $\mathrm{F}$ well water. At $10 \%$ Basin $\mathrm{F}$ water, a marked reduction of $\mathrm{NO}_{3}{ }^{-}$was observed; enhanced levels were observed at both 100 and $1 \%$. These fluctuations in the $\mathrm{NO}_{3}^{-}$levels may be indicative of the effects that would be observed when a complex toxicant like Basin $F$ water (Table 7.5) interacts with the complex microbial community such as the one responsible for the transformations of $\mathrm{N}$ in soil.

Complex changes in the $\mathrm{NH}_{4}^{+}$levels were also observed. Recovery of ammonium ion with respect to the level initially added to the reaction vessel in the test solution, was two times greater using $100 \%$ Bas in $\mathrm{F}$ water, seven times greater for $10 \%$ and six times less for $1 \%$. Both $\mathrm{NO}_{3}{ }^{-}$and $\mathrm{NH}_{4}{ }^{+}$analyses appeared to be more sensitive than $\mathrm{CO}_{2}$; however, the complex interpretation needed for these systems precludes our using them as an effective bioassay at this time. 
TABLE 7.5. Effects of Basin F Water and Well Water on Fungal Sclerotial Formation

\begin{tabular}{|c|c|c|c|}
\hline Medium & $\begin{array}{l}\text { Concentration } \\
\text { Added }(\%) \\
\end{array}$ & $\begin{array}{l}\text { Number of } \\
\text { Sclerotia }\end{array}$ & $\begin{array}{l}\text { Percent } \\
\text { of Control }\end{array}$ \\
\hline Control & & $1_{1382} \pm 99$ & 100 \\
\hline \multirow[t]{4}{*}{ Basin $F$ water } & 10 & $2042 \pm 235$ & 148 \\
\hline & 5 & $2698 \pm 33$ & 195 \\
\hline & 0.5 & $2058 \pm 116$ & 149 \\
\hline & 0.05 & $1612 \pm 213$ & 117 \\
\hline \multirow[t]{4}{*}{ Well water } & 10 & $1662 \pm 153$ & 120 \\
\hline & 5 & $1498 \pm 81$ & 108 \\
\hline & 0.5 & $1696 \pm 266$ & 123 \\
\hline & 0.05 & $1651 \pm 68$ & 119 \\
\hline
\end{tabular}

Fluctuation in biomass (dehydrogenase) was similar to that observed for $\mathrm{CO}_{2}$ analysis. The greatest inhibition occurred at $100 \%$ Basin $\mathrm{F}$ water (Table 7.4). The similarity of these results would suggest that dehydrogenase may possibly substitute for $\mathrm{CO}_{2}$ as a bioassay. The dehydrogenase assay was more time efficient and cost effective, requiring approximately 48 hours for completion of the assay, whereas the $\mathrm{CO}_{2}$ assay required up to 30 days.

\subsubsection{Summary}

The $\mathrm{CO}_{2}$ and dehydrogenase assays indicated that concentrations of Basin $F$ water would need to range from $80 \%-20 \%\left(2 \times E_{50}, E C_{50}, 1 / 2 \mathrm{EC}_{50}\right)$ in the field study proposed by the Denver workshop (see Appendix A, Soil Microbiology Studies for additional details). These large amounts would probably preclude the use of Basin $\mathrm{F}$ water at RMA. The $\mathrm{NO}_{3}^{-}$and $\mathrm{NH}_{4}{ }^{+}$assays demonstrated better sensitivity; however, the complexity of the results does not 
suggest them for bioassays at this time. The dehydrogenase assay would be an appropriate substitute for the $\mathrm{CO}_{2}$ production assay.

\subsection{DEVELOPMENT OF SCLEROTIAL BIOASSAY}

\subsubsection{Introduction}

This bioassay was developed from a species of Aspergizzus isolated in our laboratory, which readily formed sclerotia on a deformed agar medium. When grown in this medium, the fungus forms sclerotia once the density of mycelia has increased to the appropriate levels. The sclerotia are generally laid down in concentric circles, with $\sim 1400$ being produced on a $15 \mathrm{~cm}$ petri plate.

The bioassay is conducted simply by incorporating the test compound or solution into the agar medium and by placing a single sclerotia in the center of the plate to initiate growth. After a prescribed growth period, the sclerotia are counted and results from controls and test plates are compared to determine enhancement or inhibition.

\subsubsection{Results}

Results indicated differences in growth of the fungus in Basin $F$ water compared to Basin $F$ well water (Table 7.5). Basin F water markedly enhanced the formation of sclerotia with a peak value at 5\%. Basin $F$ well water was only slightly stimulatory at all concentrations. Approximately one hundred sclerotia from each level of Basin $F$ water and Basin $F$ well water were analyzed for germination; germination was essentially $100 \%$ in all tests. One sample of 100 sclerotia showed altered morphology of the mature fungi after germination, indicating a possible genetic transfarmation.

The sclerotial assay, unlike other microbiolcgical assays, is primarily based on a differentiation process. In this sense, it is similar to the seed germination/root elongation and fish egg tests. The sclerotial assay requires less than 40 man hours to complete at this time and results are recorded within 10 days. Less time is required if germination is not included. 


\subsubsection{Summary}

The sclerotial bioassay showed good sensitivity toward the toxicant tested (Basin $\mathrm{F}$ water) and some initial promise as a mutagenic assay. Increased emphasis will be given to the assay during FY 1983.

\subsection{CHARACTERIZATION OF F BASIN WATER}

The characterization of water from Basin $F$ and Basin $F$ well water, though not a specific task in the present study, does deserve comment, since this water was used in both the microbiological and plant (bioassay) studies (Section 8.0) and has been considered as the toxicant for future field studies. Most of the pertinent information gathered on the two waters is shown in Table 7.6. Basin $\mathrm{F}$ water was slightly reduced in $\mathrm{pH}$ (6.25 vs. $7.22)$, but was considerably more aerobic $(+273.4)$ than the reduced Bas in $F$ well water (+2.95). The conductivity of Basin $F$ water was twice that of the well water; however, this was not reflected in major anions and cations, which were generally 10-fold greater. This discrepancy is a result of the exceedingly high salt concentration of Basin $F$ water, which would lead to the formation of ion pairs, thus reducing the conductivity.

The high ratio of organic carbon to phosphorous for both waters would indicate that the major organic contaminant is diisopropylmethyl phosphonate.

The concentrations of several anions and cations in Basin $F$ water should be noted $(\mathrm{ppm}) ; \mathrm{NH}_{4}^{+}, 27200 ; \mathrm{SO}_{4}{ }^{-2}, 51200 ; \mathrm{Cl}^{-}, 106167$; Na, 89600; As, 16.8; $\mathrm{Cu}, 3620 ; \mathrm{F}, 6500$. Basin $\mathrm{F}$ well water showed high levels of $\mathrm{SO}_{4}^{-2}, \mathrm{Cl}^{-}, \mathrm{Na}^{+}$, $\mathrm{Mg}^{+2}, \mathrm{Ca}^{+2}, \mathrm{Sr}^{+2}$. The high concentration of $\mathrm{Mg}^{+2}, \mathrm{Ca}^{+2}$, and $\mathrm{Sr}^{+2}$ in Basin $\mathrm{F}$ well water presumably resulted from high $\mathrm{Na}^{+}$in Basin $\mathrm{F}$ water, which has entered the groundwater system, replacing these elements on the substrata and therefore increasing their soluble concentration. 
TABLE 7.6. Some Properties and a Chemical Analysis (ppm) of Basin $\mathrm{F}$ Water and Basin $\mathrm{F}$ Well Water

\begin{tabular}{|c|c|c|}
\hline Constituent & Basin $F$ & $\begin{array}{l}\text { Basin F } \\
\text { Well Water }\end{array}$ \\
\hline $\mathrm{pH}$ & 6.25 & 7.22 \\
\hline Eh & +273.4 & +2.95 \\
\hline Conductivity ( $\mu$ mhos) & 52610 & 26300 \\
\hline Color & black & light yellow \\
\hline$C$ (organic) & 67770 & 843 \\
\hline$C$ (inorganic) & 2667 & 480 \\
\hline $\mathrm{NH}_{4}^{+}$ & 27200 & 130 \\
\hline $\mathrm{SO}_{4}^{-2}$ & 51200 & 5060 \\
\hline $\mathrm{Cl}^{\top}$ & 106167 & 8980 \\
\hline $\mathrm{Na}$ & 89600 & 8320 \\
\hline As & 16.8 & 1.13 \\
\hline$P$ & 11500 & 244 \\
\hline $\mathrm{Cu}$ & 3620 & 0.05 \\
\hline $\mathrm{Ni}$ & 31.6 & 1.38 \\
\hline $\mathrm{Zn}$ & 25.7 & 0.15 \\
\hline $\mathrm{F}$ & 6500 & 88 \\
\hline $\mathrm{Mg}$ & 95 & 730 \\
\hline $\mathrm{Ca}$ & 105 & 744 \\
\hline $\mathrm{sr}$ & 3.55 & 20 \\
\hline
\end{tabular}




\subsection{LABORATORY PLANT BIOASSAYS}

\subsection{INTRODUCTION}

The initial objective of this study was to determine the effect of Basin $F$ water on seed germination and plant growth. Soil obtained from a proposed experimental plot at RMA (Section 2.1.2) was used to assess the feasibility of a field study proposed by the Denver workshop. Prior to attempting a bioassay in pots, we conducted a preliminary seed germination test using the Neubauer technique (Vandecaveye, 1948). Since we expected to evaluate up to 100 additional soil samples obtained during the field vegetative studies (Section 5.2), considerable effort was spent in modifying the method to reduce cost and to allow disposal of the experimental apparatus, in contrast to the Neubauer technique or the current EPA seed germination/root elongation tests.

\subsection{METHODS}

One hundred grams of air dried soil was mixed with various amounts of Basin $\mathrm{F}$ water (chemical analysis of the water is included in Table 7.6) for each experiment conducted.

In experiments $1-3$, the soil/Basin $F$ water mixture was placed in crystalizing dishes $(125 \mathrm{~mm} \times 65 \mathrm{~mm}$, three replicates per Basin $\mathrm{F}$ level added), planted with 100 locally obtained, disease-treated wheat seeds, and watered to field capacity ( $41 \mathrm{ml}$ distilled water). One hundred grams of washed silica sand was placed in an even layer over the top of the seeds. A glass plate was placed over the top of the dishes to reduce evaporation during germination and all dishes were incubated in a plant growth chamber. Temperature was maintained at $72^{\circ} \mathrm{F}$ and the seeds kept in complete darkness until germination occurred at about 48 hours. At that time, the lighting regime was changed to 16 hours of 1 ight and eight hours of darkness.

Once the cotyledons grew enough to touch the cover plates, the plates were removed. Moisture level in the soil was maintained by daily addition of water by weight. Water usage was recorded and the number of plants were 
counted to determine germination percentage. Seven to eight days after planting, we measured leaf lengths.

In experiment 4, the Neubauer technique was modified in that $100 \mathrm{~g}$ of soil was placed in the bottom of a $150 \mathrm{~mm}$ disposable petri dish, covered with $100 \mathrm{~g}$ of sand and enclosed in a plastic bag. Forty wheat and lettuce seeds, obtained from the Corvallis EPA laboratory, were planted and watered to $85 \%$ of field capacity $(35 \mathrm{ml})$ and the bag closed with a rubber band. This system functioned without any addition of water until the bags were removed six days after the seeds were planted. By this time, gerinination had occurred and leaves were established. An evaluation of Basin C soils was carried out using this same technique (see Section 5.2).

Soils for the pot experiment (experiment 5; see Table 8.1) were prepared by mixing $1 \mathrm{~kg}$ of soil in plastic bags with Basin $F$ water and then planting 15 seeds in each of the three quart-sized ice cream cartons. Growth chamber conditions were maintained in the same way as in the Neubauer studies.

\subsection{RESULTS}

The four bioassay experiments conducted showed that $5 \%$ Bas in $\mathrm{F}$ water allowed no seed germination (Table 8.1). In all four experiments, $1 \%$ Bas in $F$ water produced reduced seed germination and leaf growth, compared to controls. Germination was considerably higher in experiment 4 because untreated seeds obtained from EPA (Corvallis) were used. Apparently the treatment used on seed obtained locally was too strong for use with the Neubauer technique. However, the relative effects of Basin $F$ solution were similar in all experiments when compared to respective control soils. Because the results of experiment 5 (pot experiment, Table 8.1) were similar to those found in experiments 1-4, we conclude the Neubauer procedure is a valid bioassay technique.

Lettuce germination, wheat germination and wheat leaf growth were not significantly different in soils obtained from stations in Basin C (collected during the vegetation field study, Section 5.2), except for Plot 27 near the terminal point of the transect (Figure 2.7 and Table 8.2). Germination of lettuce and wheat and leaf growth of wheat plants were slightly diminished at 
TABLE 8.1. Effect of Basin $F$ Water on Wheat Seed Germination, and Leaf Length and Water Usage

Basin $\mathrm{F}$

Water (\%)

100

10

1

0.1

0.01

0 RMA soil
\% Germination

\section{Experiment 1}

$\begin{array}{cc}0 & 0 \\ 0 & 0 \\ 17.3 \pm 11.6^{1} & 2.8 \pm 3.2 \\ 45.0 \pm 1.7 & 8.9 \pm 3.6 \\ 47.0 \pm 6.0 & 7.7 \pm 3.5 \\ 46.7 \pm 3.1 & 8.4 \pm 3.7\end{array}$

Experiment 2

$\begin{array}{ll}5 & 0 \\ 1 & 32.2 \pm 1.5 \\ 0.5 & 41.7 \pm 6.8 \\ 0.25 & 39.3 \pm 5.0 \\ 0.1 & 40 . \\ \text { 0 RMA soil } & 38.3 \pm 4.3 \\ \text { 0 Ritzville } & 44.3 \pm 7.1\end{array}$

Experiment 3

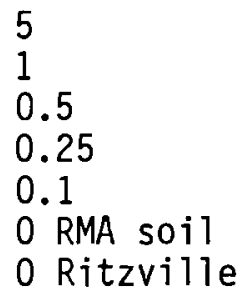

$37.3 \pm 1.5$

$39.0 \pm 3.5$

$41.7 \pm 1.2$

$40.0 \pm 6.4$

$48.3 \pm 7.2$

$53.3 \pm 14.2$

$$
\begin{aligned}
& 9.1 \pm 7.6 \\
& 8.1 \pm 3.9 \\
& 8.0 \pm 3.6 \\
& 7.6 \pm 3.4 \\
& 8.7 \pm 8.2 \\
& 5.9 \pm 3.5
\end{aligned}
$$

$$
\begin{gathered}
0 \\
8.9 \pm 3.7 \\
9.3 \pm 3.8 \\
8.8 \pm 3.6 \\
7.1 \pm 3.9 \\
7.5 \pm 3.1 \\
6.3 \pm 3.5
\end{gathered}
$$

Water Used (mI)

$$
\begin{array}{r}
47.9 \pm 1.5 \\
95.5 \pm 18.8 \\
147.9 \pm 1.9 \\
200.1 \pm 9.1 \\
207.7 \pm 8.9 \\
220.8 \pm 9.2
\end{array}
$$

\section{Experiment 4 (Modified Neubauer)}<smiles>COC(=O)O[Na]</smiles>

0 RMA soil

$$
\begin{gathered}
0 \\
48 \pm 11 \\
95 \pm 4
\end{gathered}
$$

0

$82.1 \pm 8.3$

$91.1 \pm 3.2$

$105.0 \pm 7.3$

$116.6 \pm 1.0$

$115.2 \pm 0.5$

$111.5 \pm 10.1$

$110.0 \pm 5.3$

2.5

1.0

0.25

0.10

0.0

$5.0 \pm 3.2$

$10.2 \pm 2.5$

\section{Experiment 5 (Pot Study)}

$\begin{array}{cc}0 & 0 \\ 53 \pm 18 & 1.5 \pm 1.6 \\ 93 \pm 0 & 7.0 \pm 2.1 \\ 89 \pm 3.5 & 9.6 \pm 1.3 \\ 96 \pm 7.5 & 8.5 \pm 2.4\end{array}$

$\overline{1_{\text {Mean }} \pm \text { standard deviation; } n}=3$. 
TABLE 8.2. Wheat and Lettuce Germination then Grown On Soils From Section 26 - Basin C

\begin{tabular}{|c|c|c|c|}
\hline \multirow[b]{2}{*}{ Plot \# } & \multicolumn{2}{|c|}{$\%$ germination } & \multirow{2}{*}{$\begin{array}{c}\text { Leaf length }(\mathrm{cm} \\
\text { Wheat }\end{array}$} \\
\hline & Lettuce & Wheat & \\
\hline $6^{1}$ & $94 \pm 2^{2}$ & $99 \pm 2$ & $10.9 \pm 2.1$ \\
\hline 7 & $90 \pm 4$ & $95 \pm 4$ & $10.4 \pm 2.6$ \\
\hline 8 & $94 \pm 5$ & $98 \pm 4$ & $9.9 \pm 2.4$ \\
\hline 9 & $96 \pm 2$ & $99 \pm 2$ & $10.5 \pm 1.5$ \\
\hline 10 & $92 \pm 4$ & $95 \pm 4$ & $11.2 \pm 2.3$ \\
\hline 11 & $92 \pm 4$ & 100 & $10.8 \pm 1.5$ \\
\hline 12 & $95 \pm 4$ & $96 \pm 4$ & $11.1 \pm 1.8$ \\
\hline 13 & $99 \pm 1$ & $98 \pm 0$ & $10.6 \pm 1.8$ \\
\hline 14 & $93 \pm 5$ & $64 \pm 31$ & $10.7 \pm 2.7$ \\
\hline 15 & $97 \pm 3$ & $95 \pm 0$ & $11.6 \pm 2.5$ \\
\hline 16 & $93 \pm 4$ & $98 \pm 3$ & $11.2 \pm 1.0$ \\
\hline 17 & $96 \pm 5$ & $94 \pm 4$ & $11.3 \pm 2.3$ \\
\hline 18 & $95 \pm 4$ & 100 & $11.6 \pm 2.3$ \\
\hline 19 & $96 \pm 2$ & $95 \pm 4$ & $10.3 \pm 2.3$ \\
\hline 20 & $90 \pm 7$ & $98 \pm 0$ & $10.6 \pm 1.6$ \\
\hline 21 & $96 \pm 2$ & $91 \pm 12$ & $10.3 \pm 1.8$ \\
\hline 22 & $98 \pm 0$ & $98 \pm 4$ & $10.6 \pm 2.1$ \\
\hline 23 & $91 \pm 2$ & $99 \pm 2$ & $11.0 \pm 1.4$ \\
\hline 24 & $93 \pm 0$ & $98 \pm 0$ & $10.8 \pm 1.9$ \\
\hline 25 & $94 \pm 5$ & $96 \pm 2$ & $10.8 \pm 1.8$ \\
\hline 26 & $98 \pm 4$ & $99 \pm 2$ & $10.8 \pm 1.4$ \\
\hline 27 & $88 \pm 7$ & $89 \pm 2$ & $7.6 \pm 2.3$ \\
\hline 28 & $91 \pm 9$ & 100 & $10.5 \pm 1.8$ \\
\hline 29 & $95 \pm 0$ & $96 \pm 2$ & $9.5 \pm 1.6$ \\
\hline 30 & $95 \pm 2$ & $98 \pm 4$ & $10.4 \pm 1.9$ \\
\hline Control Soil & $90 \pm 0$ & $95 \pm 4$ & $10.2 \pm 2.5$ \\
\hline $1 \%$ Basin F Sol. & 0 & $48 \pm 11$ & $5.0 \pm 3.2$ \\
\hline $5 \%$ Basin F Sol. & 0 & 0 & 0 \\
\hline
\end{tabular}


this plot. Using pooled variance estimates for wheat seed germination and leaf length (Table 8.2), we estimated that reduced germination of about $8 \%$ between Basin $C$ soils could be detected with an assurance of about $80 \%$ ( $\alpha=$ $0.05)$. To detect differences in leaf length, about a $4 \mathrm{~cm}$ mean difference would be needed, suggesting that this labor intensive measurement may be too expensive for use in a screening mode.

\subsection{SUMMARY}

Basin $F$ water applied in concentrations greater than $2.5 \%$ caused $100 \%$ inhibition of wheat or lettuce seeds in Neubauer or petri dish bioassays. Concentrations of $1 \%$ caused reduced germination and leaf growth for wheat and completely inhibited lettuce germination. Subsequent tests in pots supported the bioassay results for wheat. Thus, about $1 \%$ Basin $F$ water should be used in field plot studies suggested by the Denver workshop.

A new system using petri dishes and plastic bags to test the effect of toxic substances on seed germination was found to be inexpensive and reproducible. It has advantages over the current EPA seed germination and root elongation bioassay in that soil is used (in contrast to an eluate); moreover, the procedure is sensitive. In addition, experiments can be completed in seven days, all material is disposable, and all replications can be initiated at about the same time.

\subsection{REFERENCES}

Vandecaveye, S. C. 1948. Biological methods of determining nutrients in soils. In Diagnostic Techniques for Soil and Crops, ed. H. B. Kitchen. . The American Potash Institute, Washington, D.C. 


\section{·}

- 
APPENDIX A

DENVER WORKSHOP PROGRAM 


\section{FIELD VALIDATION OF HAZARDOUS WASTE BIOASSAYS}

March 29-30, 1982

Denver, Colorado

Program Objectives

Provide inexpensive bioassays or biomonitoring methods to assess the relative hazard of chemical waste sites.

Workshop Questions

a. Which field studies can be conducted to assess the utility of laboratory screening studies?

b. Are other field studies more useful or cost-effective in ranking hazardous waste sites?

Resources Document

Proceedings of Bioassessment of Hazardous Waste Sites Workshop, Washington, D.C., October 26-27, 1981.

Proposed Field Monitoring

Suggested strawmen for aquatic, terrestrial, microbiological, soils and sampling. 
SOME POSSIBLE ARSENAL SCENARIOS

(All can have been weathered, flooded, and be a mix of compounds)

A. Waste mixed with line and subsequent pit/trench disposal

B. Waste placed in pit/trench and covered with earth

C. Waste placed/spilled on surface and subsequently spread or plowed

D. Waste pond (wet and dry or alternately wet and dry)

E. Pond dredge spoils

F. Spray drift from ponds 
STRAWMAN SCENARIOS WHERE LABORATORY BIOASSAY RESULTS MIGHT BE COMPARED WITH FIELD STUDIES

1. All dead versus all alive or effect versus no effect i.e., no gradient.

2. Response to a continuum - i.e., gradient.

3. Mixture of 1 and 2.

4. Various chemicals heterogeneously distributed on a gradient (variables and unperdictable response).

5. Various chemicals in discrete "pockets" (several effect of no effect results).

6. Accumulation versus effect. 


\section{SOME SUGGESTED FIELD SAMPLING ISSUES}

\section{General}

1. Random or systematic samples

2. Stratification

3. Multiple contaminants which are not randomly dispersed

4. How should ancillary measures/observations be used:

a. Qualitative - based on "eyeball" observations of biota at the site

b. Quantitative - possibilities for double sampling (an inexpensive substitute calibrated a priori for an expensive measurement).

Soils

1. Representative depth

2. "Core" size

3. How best to define a gradient (if orie exists)

4. Can a preliminary soil leachate or $\in$ luate be used (i.e., Daphnia) to establish gross site characteristics?

Aquatic

1. Taxonomic problem(s)

2. Sampling devices

3. Sampling frequency

4. Ponds versus streams

\section{Terrestrial}

1. Lumped versus single samples

2. Plant size - proportionality of plant parts

3. Substrate conditions - dry to moist :soilk 


\section{STRAWMAN FIELD STUDIES}

Aquatic

Macrophytes

Phytoplankton

Terrestrial

\begin{tabular}{|c|c|c|}
\hline Organism & Measurement & Method \\
\hline Grasshopper & Biomass & Ocular estimate \\
\hline Beetles & Biomass & Pit traps \\
\hline Insects & Biomass & Drop trap (expensive) \\
\hline Plants & Biomass & Grid (inaccurate) \\
\hline
\end{tabular}

Microbiological/Soil

Soil Respiration

Resistant Bacterial 


\section{SUGGESTED BIOMONITORS/BIOACUCMULATORS}

1. Grasshoppers - organics

2. Honeybees - metals

3. Raptor castings

4. Earthworms

5. Algae

6. Phytoplankton

SUGGESTED LABORATORY BIOASSAYS (See Resource Document)

1. Daphnia - LD-50

2. Selanastrum - $95 \%$ reduction in biomass versus control at 120 hour

3. Fathead - LD-50 (48 hours)

4. Earthworm - LD-50 (7 days)

5. Soil Microcosm - $\mathrm{CO}_{2}$ evolution (30 diays)

6. Seed Germination/Root Elongation - \% reduction compared to control at 115 hours. 


\section{PERSPECTIVE - (STRAWMAN) SOIL/MICROBIOLOGY STUDIES}

Some reservations concerning the use of microbiological field studies to validate laboratory studies adopted by the EPA to assess hazardous chemical waste sites have been expressed. These reservations center in two areas: 1) the ability of microorganisms to adjust rapidly to changes in their enviornment, which may help or hinder, depending on the studies to be conducted; and 2) the definition of a field study.

A field protocol which may be useful would be to measure the respiration rates of "contaminated" soils and to compare those with rates from "clean" soils in the same vicinity. Such studies are primarily done in the field; determinations of $\mathrm{CO}_{2}$ collected from field installations are the only measurements done in the laboratory. The use of this protocol, however, depends on: 1) presence of chemicals (organic or inorganic) which repress the respiration rate; 2) availability of adequate control soils; 3 ) degree of recovery of the microbial community (i.e., development of resistant community) to a level which would not show a reduced respiration rate; or 4) ability of the microorganisms present to use the contaminant as a source of carbon or energy. Methods for such studies have been developed by wildung et al. (1975) for arid grassland soils.

Suggested studies less related to the field could include measurement of the mineralization of ${ }^{14} \mathrm{C}$-labeled compounds, such as cellulose or organic components thought to be contaminants, measurement of the mineralization (nitrification, denitrification) of nitrogen or the determination of the ratio of drug resistant bacteria to the total population capable of growth on a defined medium (currently under development by EPA at Corvallis). The mineralization of cellulose and nitrogen would measure the hazardous impact upon the microbial community where the mineralization of potential ${ }^{14} \mathrm{C}$-contaminants or the measurement of antibiotic studies would show the presence of contamination only. These studies would not be conducted in the field per se but would deal directly with soils collected from the field.

The utility of the above studies are subject to verification. It may well be that other non-microbiological studies may be of more use in field validation. The Workshop should discuss this in depth. 


\section{PERSPECTIVE - (STRAWMAN) TERRESTRIAL STUDIES}

In the terrestrial studies, a broader view inight include studies to determine if the risks are erally greater than the bioassays technique might detect. As a result the EPA Rocky Mountain Aresenal Field studies must address three separate needs: 1) to validate the bioassay ranking technique, 2) to ascertain the overall environmental risk from the arsenal site even though results cannot be related to the bioassay technique, and 3) to asceratin the general bio-availability of contaminants for the overall area.

Some specific ideas for field experiments are outlined below for each of these areas.

Validation of the Bioassay Technique

This would be accomplished by conducting studies similar to those used for EPA's bioassay test or at least the kinds of studies that could be related to the bioassay technique.

Studies would be conducted for a series of burial sites over a range of contaminant levels. Both bioassay and field studies would be conducted for each. Some specific examples include:

a. Test plant (barley, peas, etc.) growth studies. Fill lysimeter with we11-mixed soil representative of each study area. Measure culm length, leaf lengths, and seed head length periodically. Clip and determine biomass (dry weight) at teh end of the study period. Compare values for treatment and control areas. Percent difference between treatment and control field studies would be compared with percent difference in the bioassay lab study.

b. Test plant germination studies. This task would actually be part of (a) above. A known number of seeds would be planted in each lysimeter and the percent germination recorded. Comparisons would be between treatment and controls in the field and lab respectively and also between field and lab treatments and field and lab controls. 
APPENDIX B

STATEMENT OF WORK 


\section{STATEMENT OF WORK}

PROJECT TITLE:

SCOPE:

PRINCIPLE INVESTIGATORS: Dr. J. M. Thomas, Project Manager/Coordinator

Dr. C. E. Cushing

Dr. J. E. Rogers

Dr. L. E. Rogers

Introduction

The overall goal of the Hazardous Materials Assessment Research Program is to provide the scientific and technical information necessary to enable the responsible Agency's offices to discover, control and clean up hazardous substances that have been released to the environment from spills or uncontrolled waste sites. The Agency is mandated these responsibilities by CERCLA (1980) and RCRA (1976).

An initial step in providing the needed information was made with the identification of laboratory bioassay procedures designed to biologically evaluate the relative hazards of hazardous waste materials. The procedures were selected following an EPA sponsored workshop entitled "Bioassessment of Hazardous Waste" held in Washington, D.C., October 26-27, 1981. The participants critically evaluated the available protocols that use biological testing to assess the risks from hazardous materials and identified those that would be applicable. A subsequent workshop, entitled "Field Validation 
of Hazardous Waste Bioassays", held in Denver, Colorado, March 30-31, 1982, evaluated proposed aquatic, terrestrial and microbiological field studies that could be used to validate the laboratory bioassay procedures. Participants at the Denver workshop also indicated that certain field bioassessment protocols may be developed that have no corresponding laboratory tests and therefore, could stand alone as site assessment tools.

Personnel from the Rocky Mountain Arsenal (RMA) have indicated that they want to cooperate on this study and will make the Arsenal available to be used as a field laboratory. Because of the unique history and the availability of some environmental data at RMA, the Arsenal will be an excellent site to initiate the field evaluations of the bioassessment procedures.

A six-task plan has been developed to conduct and evaluate a series of multidisciplinary studies.

\section{Task Descriptions}

\section{Task 1 - Project Management/Coordination}

The multiple disciplines and extensive interrelationships involved in this project will require an extensive management/coordination effort. This task will provide for the continued coordination with ERL-Corvall is to assure the synchronization with the laboratory bioassay rests being conducted concurrently with this field study. Continued conmunications are absolutely essential so as to make any adjustments in scheduling as quickly as possible. This task will also provide personnel at ERL-Corvêllis periodic progress reports, as well as a final project report. It will facilitate presentations of findings at appropriate technical meetings, as well as the documentation and publication in peer-reviewed journals.

The direction and continuing critical review of a complex multi-disciplinary project such as this requires the leadership of an experienced senior staff member. It is anticipated that Dr. J. M. Thomas will serve as the project manager. Dr. Thomas will provide both technical and financial management of this project. In addition, he will be responsible for keeping the designated Environmental Protection Agency

\section{B. 2}


Project Manager, Mr. William Miller, fully informed during the period of this research. Briefings on technical progress will be held frequently and appropriate changes in the field study will be made only after discussion and agreements with Mr. Miller.

A more detailed work plan will be produced in this task as soon as a more complete view of the field study and corresponding laboratory studies are developed. Initial scoping studies are planned during the first growing season. This will help assure that the studies selected are applicable and workable before committing the major portion of funds to any questionable experiment. All of the study will be subject to budgetary and seasonal limitations.

\section{Task 2 - Microbiology and Soils}

The primary scope of this task is to develop and conduct a field study to examine the utility of bioassays, with emphasis on soil microbial effects. Because significant modification of the initially identified soil respiration bioassay method was strongly suggested at the Denver Workshop, a modified soil microbial effects bioassay will be conducted concomitantly with the original field studies to validate both.

The modified soil microbial effects assay consists of mixing contaminated soil and a carbon/nitrogen source ( $1 \%$ alfalfa) with control soils (regional control, site control) and monitoring with time (2-4 weeks), the effects on production of $\mathrm{CO}_{2}$ (respiration), nitrification $\left(\mathrm{NH}_{4}+\mathrm{NO}_{3}{ }^{-}\right.$, and total N) and biomass (dehydrogenase assay). Soils will be incubated at $60 \%$ of moisture-holding capacity. The production of $\mathrm{CO}_{2}$ will be monitored continuously while biomass and nitrification will be measured at several intervals during the incubation period. Effects will be defined in terms of the extent of inhibition relative to analogous unamended controls.

Field plots located at RMA, both amended and unamended with alfalfa, will be irrigated with various levels of a filtered, chemically we11-characterized, "hazardous" waste water (WCHW) from RMA. Before preparation of the field plots, a laboratory feasibility study will be conducted to determine at what level WCHW will show a $50 \%$ inhibition in 
respiration in a representative soil from the field study site. The WCHW levels used in the field will approximate $0,1 / 2 \times E C_{50}, E C_{50}$, and $2 \times E C_{50}$. After the field plots are in place, they will be monitored for the production of $\mathrm{CO}_{2}$ over a twenty-four hour period at prescribed intervals, during the spring and fall, as determined from temperature/moisture decomposition models previously established. At the same time, soils will be analyzed for $K C 1$ extractable ammonium, and nitrate, total soil nirrogen, biomass (dehydrogenase assay) and inorganic and organic components deemed important from the initial characterization of WCHW. In addition to the measurements associated with the modified bioassay, soil samples will be analyzed, at a minimum, for $\mathrm{pH}$, conductivity, TC, DOC, trace metals, and major cations. For selected samples taken at the time field plots are preared, a comprehensive soil analysis will be conducted, which will also include moisture holding capacity, particle size distribution, and mineralogy. Additional studies will be conducted depending on initial results. Interaction with the terrestrial component is anticipated as well as farticipation in the aquatic research as needs arise.

\section{Task 3 - Aquatic Ecology}

Aquatic investigations will be conducted to determine if the biotic populations inhabiting lakes and streams at the RMA have been affected by chemicals from plant operations and to provide data for field validating bioassay results. Before effects can be ascertained, however, a data base from which to compare the biotic indices must be established. These data can be obtained from either an adequate literature data base to establish "normal" parameters, or comparison of impacted populations with those of a non-impacted population in a suitable control body of water. Literature sources may be useful, especially for assessing ralative fish health and possibly for gross comparison of plankton data. Comparison with a control body of water, is the most scientifically defensible choice.

An initial field trip will be made to collect samples of all trophic levels in Lakes Mary and Ladora, as well as information on the basic limnological characteristics of these lakes (assurning that these are the only two lakes at RMA which will have stable water levels), and to evaluate 
candidate control sites and collect similar samples for limnological characterization purposes. Laboratory analyses of samples from all lakes will include basic taxonomy of all trophic levels and gross chemical characterization of the water. The selection of a control site, will be done in cooperation with scientists from the Colorado Department of Natural Resources and the U. S. Fish and Wildlife Service. Subsequent, more extensive, field studies will be designed as outlined in the project management task to study those aquatic components identified by the Denver Workshop participants. Studies suggested include basic taxonomical characterization of algae and invertebrates and an assessment of ecosystem function (e.g., primary productivity, secondary production). Population age structure and condition factors for the dominant fish species will be compared. Caged bioassays of selected species may also be initiated.

Statistical comparison of data from Lakes Mary and Ladora with those from the control lake(s) will provide an assessment of the effect of RMA operations on the aquatic ecosystems. These results will also be used to judge the suitability of the laboratory bioassay tests to predict environmental impact.

Task 4 - Terrestrial Ecology

The proposed terrestrial field studies were designed within the general framework outlined at the Denver Workshop. The expectation is that a concentration gradient of toxic contaminants can be documented extending away from some specific locations (e.g., Basins A, F). Some of the proposed studies are designed to be established along such a gradient, while others would employ a paired plot design. Interaction with the microbiology soils component of this project will help define the needed areas and greatly benefit both tasks.

A previous site visit to RMA provided valuable background information. However, a more specific site inspection will be required prior to selection of specific study sites and designs.

The location of study transects, and treatment or control areas must depend upon information concerning the types, location and quantitites of 
toxic materials present. Sufficient information may be available from RMA reports and staff so that study sites can be located based on contaminant concentration criteria. If not, some additional chemical analyses may have to be conducted; therefore, limiting the initiation of some of the suggested field assessment studies this year. Anticipated field studies are outlined below:

1. Plant Field Studies

Study transects will be located within areas extending away from toxic waste sites along a gradient of decreasing concentrations. Plant parameters to be measured will include: 1) total plant heig̣t; 2) grass leaf lengths; 3) grass seed head lengths; 4) phenological stage:s; 5) plant biomass; and 6) plant cover by species. Suggested study areas include locations near Basin $A$, Basin F, dredged sediments from Derby Lake and within a control area near the eastern boundary.

\section{Plant Lysimeter Studies}

Composite soil samples will be collected at the same time and locations from where soils are to be collected for the labcratory bioassay tests and for the microbiological tests. These soils would be mixed and placed within small weighing lysimeters located near the collecting points. This approach will permit assessment of growth characteristics of plants not preadapted to the site contaminants and exposed to actual site field conditions of temperature, winds, sunlight, etc. Parameters for study may include: 1) total growth; 2) leaf lengths; 3) biomass; 4) germination and 5) phenology. Barley would probably be the plant species selected for study. These studies should commence in May and extend until September.

\section{Small Mammal Population Studies}

Trapping transects will be established within the general study areas identified above. Each transect would consist of a number of live traps (probably 50-75, depending on smal1 mammal abundance) located at 10-meter intervals. The traps would be operated for three days during each trapping session. 
Captured animals will be identified as to species, their sex and general health determined. They would be weighed and given their own unique mark (toe clip) and released. Subsequent trapping sessions would provide comparisons as to health, resident status, reproductive activity, weight gains and population structure between small mammal populations occupying areas of differential toxic concentration levels. These studies should commence in May and continue on a monthly basis through 0ctober.

4. Microarthropod Abundance

Litter samples $\left(0.1 \mathrm{~m}^{2}\right)$ will be randomly collected from sample transects located within previously identified study areas. Microarthropods will be extracted using Berlese funnels located on site. The biota would be identified and biomass estimates obtained. Comparisons between treatment and control study areas will be made based on: 1) taxonomic composition; 2) density; and 3) biomass. This work should be conducted during the period of anticipated peak microarthropod abundance (probably June).

\section{Honeybee Response}

The response of honeybee colonies in terms of individual bee mortalities and brood production will be ascertained for three onsite locations at RMA and for one off-site control location. This approach provides an indication of the environmental status for the general area rather than for a particular location since the bees forage over a wide area. Inclusion of this task is dependent on availability of suitable forage and water.

Task 5 - Statistical Design and Analysis

Specific study designs will be devised in concert with investigators conducting the research under Tasks 2-4. Each design will be constructed to assess the impact hypothesis as well as to provide data for intercomparisons with laboratory bioassays. Recommendations on sampling frequency, subsampling, compositing, and the like will depend on the speri:i i studies conducted. Special attention will be given the statistical issues (which are independent on specific field studies) presented at the Denver Workshop, some of which are listed below:

1. Random vs. systematic sampling 
2. The need for stratification

3. The use of double sampling

4. The paired plot design for impact

5. How to obtain representative soil samples

6 . How best to define gradients of toxic wastes

\section{Task 6 - Supportive Chemical Analyses}

Funds in this task are reserved for site chemical reconaissance, sample chemical analyses not anticipated at this time and nonroutine and specialized analyses. 
APPENDIX C

FY82 PROJECT PLAN 
Project Plan

Field Evaluation of Hazardous Waste Site

Bioassessment Protocols

I. Objective

The objective of this project is to conduct field studies to assess the utility of laboratory bioassay tests for evaluating the potential environmental impacts of hazardous waste sites. The field studies will be coordinated closely with laboratory bioassay tests being conducted concurrently by ERL-Corvallis or at other laboratories. Other bioassessment tests that are unique to field situations will also be evaluated and/or developed to supplement available laboratory bioassays. The eventual product of this study will be the development of information necessary to produce user-oriented documents that outline protocols for using bioassay techniques to assess the potential risks of hazardous waste sites on public health, welfare or the environment.

During the course of the initial six months of research we plan to

1. Determine the variability (both within and between laboratories) for six bioassay procedures using contaminated soil samples from the Rocky Mounta in Arsenal (RMA).

2. Assess within and between plot variability for field assessment techniques (small mammals, plants, and honeybees) so that field studies can be designed to detect a defined biotic change.

3. Establish three field plant transects which are apparently a) contaminated, b) appear contaminated and 3) control. Soil samples will be taken and subsequently subjected to bioassay if statistical analysis reveals a difference in plant communities.

4. Assess the feasibility in the laboratory of using Basin $F$ water to artificially contaminate RMA soil to supply information for the design of a field plot study in 1983.

C. 1 
5. Attempt to obtain preliminary data on any promising field or laboratory bioassessment techniques not currently mentioned in the statement of work.

6. Obtain field data to assess the ecological status of RMA lakes and compare these observations to results from bioassessment testing. After conclusion of the initial research, results will be analyzed and used to design more extensive field studies for the spring-summer of 1983 at RMA as outlined in the statement of work. It is anticipated that one or more transects or sets of field plots will be established based on variance estimates obtained during FY 1982. Estimates of animal abundance and/or floral community structure and/or in situ microbiological activity and/or plant lysimeters (see statement of work) will be used to assess contamination in the field. Appropriate soil samples will be cbtained for concurrent bioassay. In addition, a field plot located on RMA will be established to assess the effect on in situ plants and microbial populations from an "introduced" contaminate (likely Basin F water). The exact study configuration, replications, and dosages will be prescribed after 1982 preliminary work. Again soil samples will be obtained for bioassay. Inclusion of other field tests (i.e. microarthropjd, grasshoppers and honeybees) and laboratory bioassays (i.e. Neubauer technique for germination and plant growth) will depend on 1982 results. 
APPENDIX D

LOCATION OF 1982 FIELD SAMPLING SITES AT ROCKY MOUNTAIN ARSENAL 


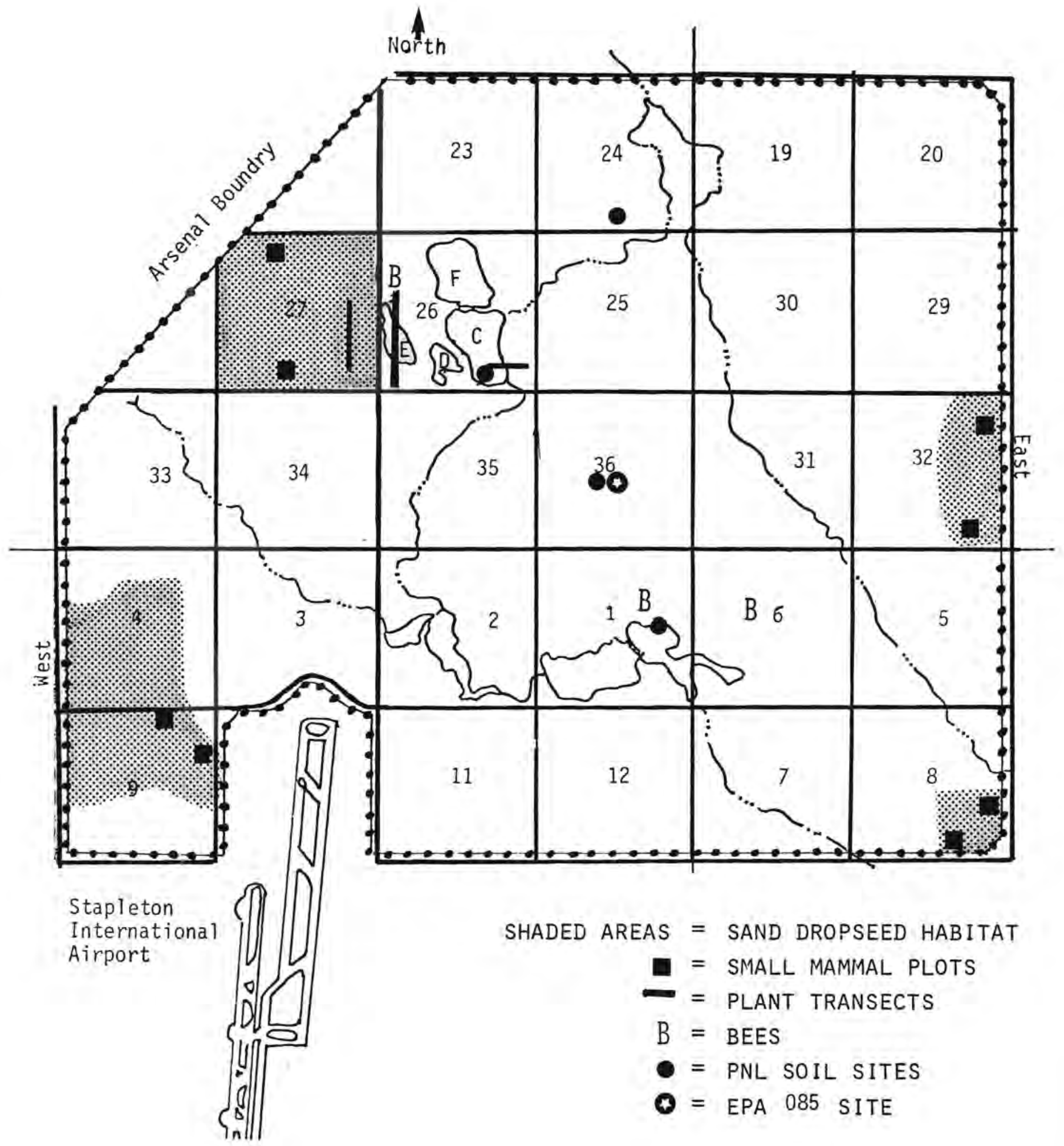

D. 1 

PNL -4614

UC-11

DISTRIBUTION

No. of

No. of

Copies

Copies

OFFSITE

OFFSITE

Mr. William Miller

Environmental Protection Agency

200 S.W. 35th Street

Corvallis, OR 97330

Dr. Spence Peterson

Environmental Protection Agency

200 S.W. 35th Street

Corvallis, OR 97330

Dr. W. E. Fallon

Office of Research and Development

Environmenta 1 Protection Agency

Waterside Mall

401 M Street S.W.

Washington, DC 20460

27 DOE Technical Information Center

Dr. Ken Duke

Battelle Columbus Laboratories

505 King Avenue

Columbus, Ohio 43201

Dr. Douglas S. Robson

Biometrics Unit

337 Warren $\mathrm{Ha} 11$

Cornel1 University

Ithaca, NY 14853

Dr. W. S. Osburn

Ecological Research Division

Office of Health and

Environmental Research

Department of Energy

Washington, DC 20545

Dr. R. L. Watters

Ecological Research Division

Office of Health and

Environmental Research

Department of Energy

Washington, DC 20545

Mr. Steve Edland

Huxley College

Bellingham, WA 98225

Dr. Jerry Bromenshenk

Environmental Studies

University of Montana

Missoula, MT 59812

Dr. Brian Anderson

Rocky Mountain Arsenal

Commerce City, CO 80022

Dr. Bill McNeil

Rocky Mounta in Arsena 1

Commerce City, CO 80022

Dr. Dave Thorne

Rocky Mountain Arsena 1

Commerce City, CO 80022

Dr. Bi11 Trautman

Rocky Mountain Arsena 1

Commerce City, C0 80022

Dr. Michael Witt

Rocky Mountain Arsenal

Commerce City, CO 80022

Distr. -1 


\section{DISTRIBUTION (Cont.)}

No. of

Copies

ONSITE

DOE Richland Operations Office

H. E. Ransom

49 Pacific Northwest Laboratory

C. D. Becker

P. A. Beedlow

K. E. Byers

J. F. Cline (2)

M. I. Cochran

C. E. Cushing (2)

L. E. Eberhardt

K. A. Gano

N. R. Hinds

S. M. Li

D. H. McKenzie

M. C. McShane (2)

T. L. Page

G. L. Poole

W. L. Rickard

J. E. Rogers (2)

L. E. Rogers (2)

R. G. Schreckhise

J. C. Simpson (2)

J. R. Skalski (2)

J. A. Strand

J. M. Thomas (10)

P. Van Voris

B. E. Vaughan

D. G. Watson

R. E. Wildung

Publishing Coordination (2)

Technical Information (5) 